\title{
Pipes, Wires, and Bicycles: Rails-to- Trails, Utility Licenses, and the Shifting Scope of Railroad Easements from the Nineteenth to the Twenty- First Centuries
}

\author{
Danaya C. Wright* and Jeffrey M. Hester**
}

This Article responds to a series of class action suits filed against railroads, telecommunication companies, and the federal government claiming that once railroads abandon their corridors, all property rights shift to adjacent landowners. This Article reviews the state law on this matter and offers a theory of how courts should handle these cases. After discussing the history of nineteenth-century railroad land acquisition practices, we analyze the scope of the easement limited for railroad purposes. We then discuss the role abandonment plays in affecting the rights of thirdparty users of these corridors as well as successor trail owners. We conclude with a theory of railroad easements that interprets the railroad's powers based on the public participation that helped create and establish these corridors and the tenuous claims of adjacent landowners.

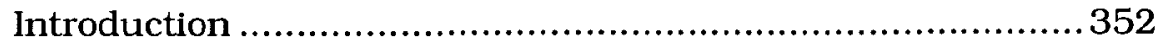

I. The Class Action Challenges to Corridor Conversion .....356

A. Rails-to-Trails ............................................ 356

B. Utility Licenses .......................................... 359

C. The Legal Arguments Against Multiple Use and Conversion of Rail Corridors .............................360

Copyright $(\mathcal{C} 2000$ by The Regents of the University of California

* Assistant Professor of Law, University of Florida Fredric Levin College of Law. The authors would like to thank the Fredric Levin College of Law for its generous support of this research as well as the Rails-to-Trails Conservancy and the Indiana Trails Action Group for their unceasing support.

** Associate, William J. Tucker \& Associates, Indianapolis, Indiana. 
II. The History of Railroad Land Acquisition Practices........365

A. 1830-1860: The Railroads Herald a Bright Future... 366

B. 1860-1871: Reckless Expansion ......................... 372

C. Post-1871: The Glow Fades............................ 374

D. What the Railroads Own ............................... 376

1. Property Interests in a Rail Corridor .................377

2. Methods of Acquisition................................379

3. Construction of Railroad Title Documents ..........381

E. What the Railroads Can Do with What They Own....386

III. The Limited Easement for Railroad Purposes ................389

A. A Right-of-Way by Any Other Name . . ...............391

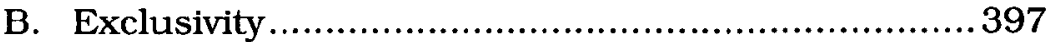

C. Physical Dimensions of the Easement ................. 403

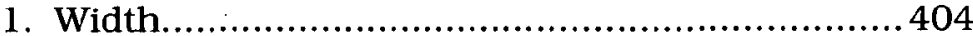

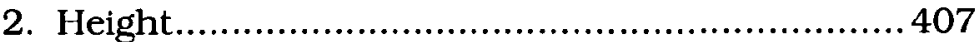

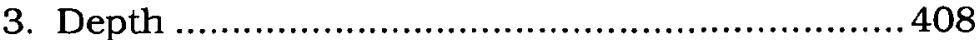

D. Scope of the Easement..................................414

1. Telephone and Telegraph Cases ......................415

2. Incidental Use Doctrine.................................421

3. Modern Fiber Optics and the Current Class Action Suits ............................................. 426

4. Using the Telephone Cases as Precedent ............ 431

E. The Scope of the Railroad Easement- Revisited .....432

IV. Abandonment....................................................... 434

A. Abandonment of a Common Law Easement ...........434

B. Shifting Public Use of the Railroad Right-of-Way .....441

C. Rails-to-Trails............................................. 447

D. Railbanking .............................................453

V. A Unified Theory of Multiple-Use Railroad Easements ... 459 Conclusion ............................................................ 464

INTRODUCTION

The digital age has arrived in the United States with our multitude of phone, fax, and internet lines, satellite TV hookups, and wireless video conferencing. We can use our cell phones to send email, we can fax our home videos over the internet, and we can hear a pin drop talking to our great uncle Al in Pago Pago. But while we are devising endless ways to save precious time while still remaining connected, we spend more time in our cars stalled in traffic jams or driving detours to avoid what seems to be an endless procession of orange cones, torn-up streets, and jackhammers laying the millions of miles of fiber-optic cable necessary to build that information superhighway. One 
commentator called it "the Great Dig of "99." Nearly 150 years after the great national surge to link the Atlantic and Pacific coasts by railroad, deregulation of the communications industry has led to a high-tech race to the bottom- that is, to the bottom of our streets and highways. ${ }^{2}$

As the Washington Post bemoaned, these disruptions are not simply a matter of inconvenience to motorists due to traffic jams and lengthy detours. ${ }^{3}$ Technology companies are using public rights-of-way with little or no compensation and without comprehensive planning. Combined with the hasty work done by most fiber-optic contractors, the new maze of underground utility networks will almost certainly cause periodic service disruptions and deteriorating streets. "Where this is going to hit the fan is when all these cities are faced with enormous reconstruction bills to rebuild their streets.... . It's going to show up in the next three or four years as a huge hit on the local taxpayer."

One quick and easy solution has been to locate fiber-optic cables in railroad corridors where disruptions and licensing costs are minimal. ${ }^{5}$ But what rights do railroads have to grant a license, subeasement, or a lease to a utility company? Not surprisingly, the rush to wire the country has led to a rush of lawsuits. With predictions that telecom traffic is expected to grow eleven-fold by $2002,{ }^{6}$ the legal issues raised by the growth of fiber optics threatens to seriously hamper technological development and overwhelm our already crowded courts. With regard to railroad corridors, twenty-five class action suits have been filed by landowners adjacent to rail corridors challenging the railroad's ownership interests in abandoned corridors and the rights of utilities to lay cables in those linear corridors. ${ }^{7}$ These lawsuits are particularly aimed at those rail corridors that

1. Justin Gillis \& Jackie Spinner, A Nation Plugged In and Dug Up: Streets Scarred in Race to Wire America, WASH. POST, July 15, 1999, at A1.

2. See id. In Washington, D.C., for instance, nine different communications companies were simultaneously laying cable this summer somewhere in the streets of the city, often in streets that had just been torn up by a competitor weeks before.

3. See id.

4. Id. (quoting Nicholas Miller, a local government attorney who worked to defend Prince George's County, Maryland, in a court fight over the government's right to collect a percentage of gross revenues from the telecom companies for the privilege of using the public streets).

5. See Frank Wilner, Rallroads: Not Just for Trains Any Longer, 6 J. TRANSP. L. LOGISTICS \& POL'Y 273, 275 (1998).

6. See Gillis \& Spinner, supra note 1.

7. See Elizabeth Amon, Working on the RRs: Simple Property Case Sparks 25 Class Actions Against RRs, Telecoms, NAT'L L.J., Aug. 16, 1999, at Al. 
have been converted to recreational trails under the popular rails-to-trails program. Moreover, the legal team bringing these suits appears to be gearing up to file at least twenty more class actions in the next few months.

The plaintiffs in these cases argue that any non-railroad use of a rail corridor violates the grant that originally conveyed the corridor land to the railroad. They claim that the railroad easement cannot accommodate concurrent utility use of conversion to a trail. Because they involve countless deeds, numerous parties, and complex issues, these cases could tie up the courts for years, paralyze the railroad and telecommunications industries well into the next century, and cost taxpayers billions of dollars. ${ }^{8}$ These cases have garnered enough local and national media attention to give them an air of credibility that they lack on the legal merits. While the cases themselves are likely to be unsuccessful, the issues they raise will only grow more important as development and growth continue to put tremendous pressures on the environment, and preservation of land takes a backseat to the transitory interests of mining, timbering, and ranching. ${ }^{9}$

8. See generally Amon, supra note 7. For example, in the case of Clark v. CSX Transportation Inc., No. 29D03-9308-CP-404 (Ind. Super. Ct. Nov. 26, 1997), the judge imposed a stay on CSX to prevent it from disposing of any of its "abandoned" corridor land in the State of Indiana, which had a chilling effect on those parcels held by the railroad in fee simple title.

9. Most of these cases have been filed by members of the private property rights movement, a movement that emphasizes the near-absolute nature of private property rights and seeks to limit governmental regulation or limitation of those rights. The property rights movement, a broad coalition of developers, mining companies, manufacturers, industrialists, and corporate farmers, in concert with such conservative think tanks as the Cato Institute and the Competitive Enterprise Institute, has funded extensive litigation challenging a wide variety of environmental and growth management regulations. The movement has also sponsored legislation at both the state and federal levels that would require compensation for the effects on land use rights above and beyond the protections recognized by the due process or takings clauses of the state and federal constitutions. Property rights advocates have spurred extensive debate in political circles about the legitimate scope of property regulations and have pushed for changes in laws that would limit interference with private land use. When railroads allow radical new uses of their corridors without consulting the owners of the servient estates, they violate the property rights of the owners. Some property rights advocates even advocate the self-help methods of digging up and severing fiber-optic cables when the utility company acquires a license to lay cable without compensating the fee owner directly. See generally Charles H. Montange, Fixing the Unbroken in the Federal Railbanking \& Trail Use Statute: A Rejoinder to "Unhappy Trails", 6 J. LAND USE \& ENVTL. L. 53 (1990); David J. Russ, How the "Property Rights" Movement Threatens Property Values in Florida, 9 J. LAND USE \& ENVTL. L. 395 (1994); Glenn P. Sugameli, Takings Bills Threaten Private Property, People, and the Environment, 8 FoRDHAM EnVTL. L.J. 521 (1997); William Michael Treanor, The Armstrong Princtple, The Narratives of Takings, and 
In this Article, we describe the legal arguments and existing law at the heart of the current cases. We then survey the foundation of the railroads' property rights: nineteenth-century railroad deeds and land acquisition practices. Once this foundation is established, we focus on the creation, content, and termination of the easement for railroad purposes. ${ }^{10}$ Finally, we seek to construct a coherent theory of how courts should resolve these suits to protect the rights of all interested parties: the landowners, the railroads, the utilities, and the public. Although we believe that a few situations exist in which the current class action plaintiffs are legally entitled to a recovery, those cases are few in number and are best handled through pre-existing quiet title mechanisms. We argue that the use of the class action mechanism is inappropriate and may in fact work an unconstitutional taking of the defendants' property rights. ${ }^{11} \mathrm{We}$ also discuss the public's rights in these quasi-public corridors to discover how best to refine our laws on railroad easements to achieve a balance between the rights of all interested parties.

Compensation Statutes, 38 WM. \& MARY L. REV. 1151 (1997); Ruth Marcus, Issues Groups Fund Seminars for Judges; Classes at Resorts Cover Property Rights, WASH. POST, Apr. 9, 1998, at A1; John Echeverria, The Politics of Property Rights (visited May 1, 2000) <http://www.envpoly.org/papers>.

10. Numerous courts and commentators have grappled with the railroad easement. Is it an easement that functions like a fee simple, or a defeasible fee, or some new category of property right that exists somewhere in between and in contravention of the rule against new estates? See infra Part III.A.

11. Because title to land is a product of state common law, class action suits may well be inappropriate as vehicles to determine rights that vary dramatically across state lines. As the leading authority on eminent domain explains,

The question of whether a certain use of land already subject to a public easement is an additional servitude, thereby entitling the owner of the fee to compensation for such use,... depends for its answer upon a precise definition in each case of the limits of the original public easement. The extent of the easement taken for highways, railroads and other public works depends upon the statutes of the states and the customs of different parts of the country. The disagreement among jurisdictions in determining what constitutes an additional servitude does not necessarily indicate erroneous conceptions of fundamental principles of constitutional law upon one side or the other, but merely illustrates the divergence in the character and extent of certain familiar public easements throughout the United States.

NiCHOLS' THE LAW OF EMinent Domain \$ 9.04 (Julius L. Sackman ed.. 3d ed. 1993). In the "nationwide class action" certified in Indiana, Hinshaw v. AT\&T, No. 29D01 9705CP-000308 (Ind. Super. Ct. filed Nov. 6, 1996), AT\&T successfully moved to transfer the case to federal district court, where a subclass of plaintiffs, Indiana landowners, settled in April 1999. 
I

THE CLASS ACTION CHALLENGES TO CORRIDOR CONVERSION

The demise of the railroad system has created unprecedented legal issues. By the end of the year 2000, nearly fifty cases questioning the use of abandoned railroad corridors for other public purposes will be working their way through the courts. These cases challenge two distinct new uses of rail corridors: ${ }^{12}$ conversion of rail corridors for recreational use, and use of rail corridors to string utility wires or bury fiber-optic cables. Both types of challenges, however, rely on similar legal arguments.

\section{A. Rails-to-Trails}

Recycling railroad corridors has been a regular practice for as long as railroads have existed. When corridors are abandoned because they are no longer profitable, or because the line cannot accommodate the requisite business, most railroads continue to hold onto the property for a number of years. In many cases, the assets from one failing line would be purchased by a more robust company and reactivated. ${ }^{13}$ The sale of one railroad's assets, including real property, to another railroad posed no great legal difficulties because the use of the land stayed the same. But in other situations, the rail corridors would be replaced with highways, canals, tramways, electric trolleys, or tollroads. ${ }^{14}$ One of the first conversions of an abandoned corridor to a trail occurred in the 1930s when the South Carolina Canal \& Railroad Co. corridor was converted to the Cathedral Isle trail in South Carolina. ${ }^{15}$

The rails-to-trails program was born after President Johnson signed the National Trails System Act in 1968 and Congress, responding to the alarming increase in railroad abandonments and the growing need for alternative transportation corridors, implemented what has come to be called its "railbanking" policy

12. The issues may, of course, overlap in any particular rail corridor. For example, trail groups have often acquired the railroads' rights through quit-claim deeds to corridors that may already have existing utility lines or may benefit from the fees generated by these licenses. We treat the two classes of cases separately, however, because conversion to trail use ultimately is a question of consecutive uses after abandonment, while utility use is ultimately a question of concurrent use.

13. Most of the active lines today went through two or three owners.

14. See infra Part V.B (discussing shifting public use doctrine).

15. See Hitchcock Foundation, Cathedral Aisle Trail Brochure. The Hitchcock Foundation manages the trail as part of Hitchcock Woods. 
through its amendment of the Trails Act in $1983 .{ }^{16}$ Under that statute, the Surface Transportation Board (STB) oversees the discontinuation of rail services and may preempt the operation of state property laws to preserve the railroad easements for possible future reactivation of rail services. ${ }^{17}$ The STB may also permit a recreational trail in the corridor so long as the use is not inconsistent with the preservation of the corridor for possible future reactivation for rail service. ${ }^{18}$ The National Rails-to-Trails Conservancy was founded in 1986 to take advantage of these administrative opportunities. ${ }^{19}$

The principal goal of the rails-to-trails program is to preserve from fractionation valuable rail corridors that were assembled at a tremendous cost to the public. By preempting state property laws, the railbanking statute merely keeps the railroad's property rights intact during a period of nonuse while the country gets its transpiration needs figured out. During the period of railbanking, however, because the railroad's rights continue, interim trail uses may be made of the corridor, as well as continuing utility use. These linear corridors make ideal public parks to link neighborhoods, schools, and shopping areas, and to link urban centers with suburbs and rural communities.

Probably the greatest success story of the Rails-to-Trails movement has been the revitalization of innumerable small towns that nearly died from the construction of interstate highways. Small towns that had thrived from the boom of railroad services in the last decade of the nineteenth century and into the early part of this century became ghost towns as jobs moved to the cities and workers followed. With the arrival of railtrails, many of the quaint, small towns of rural America have been reborn. ${ }^{20}$ Every state that has encouraged these greenbelts has seen a tremendous boom in tourism, a rise in property values along the corridors, and a rise in the environmental

16. 16 U.S.C. $\$ \$$ 1241-1251 (1994); see also Rails-to-Trails Conservancy, America's Vanishing Rail Network (visited May 1, 2000) <www.railtrails.org/ vansh.html>.

17. 16 U.S.C. $\$ 1247$ (d) (1994); see also Montange, supra note 9, at 55-56.

18. 16 U.S.C. \& 1247 (d) (1994).

19. The Rails-to-Trails Conservancy is a non-profit environmental organization that assists in trail conversion by monitoring abandonments, aiding local trail groups in acquiring the corridor, sometimes funding the land purchase and then reselling it to local managers, and then alding with the construction and operation of the trail at the initial stages. See Rails-to-Trails Conservancy (visited May 1, 2000) <www.railtrails.org>.

20. Rails-to-Trails Conservancy, Economic Benefits of Rail-Trails (visited May 1, 2000) <www.railstrails.org>. 
integrity of their neighborhoods.

Perhaps the biggest boon to the rails-to-trails program was the passage of the Intermodal Surface Transportation Efficiency Act (ISTEA) in 1991 that mandated ten percent of federal highway funds be spent on transportation enhancements and that qualified rail-trails for federal transportation funding. ${ }^{21}$ In the first five years of ISTEA spending, over fifty percent of enhancement funds, or over $\$ 800$ million, was spent on rail trails and bicycle and pedestrian facilities. ${ }^{22}$ The nation's commitment to enhancements on rail trails was renewed when ISTEA was replaced in 1999 with TEA21. ${ }^{23}$

But the rails-to-trails movement is under attack by these class action suits. Currently, the 200 mile Katy trail, from Sedalia to Machens, Missouri, is under legal challenge by adjacent landowners. ${ }^{24}$ So, too, is the 321 mile Cowboy Trail between Chadron and Norfolk, Nebraska. ${ }^{25}$ The cases began as class action challenges to particular corridor conversions, but have now grown, with the help of funding by conservative property rights groups like the John M. Olin Foundation and the National Farm Bureau Association, ${ }^{26}$ into national class action suits attacking the railbanking statute under the Takings Clause. Although the legality of the 1983 NTSA amendment was upheld by the Supreme Court in the 1990 decision of Presault $v$. United States, ${ }^{27}$ the Court left open the question of whether the railbanking act worked a taking when it pre-empted state property rights. ${ }^{28}$ Their legal arguments are discussed later in this Article $^{29}$ because these arguments have been adopted by plaintiffs in a newer breed of cases, those that challenge the use of rail corridors for utilities.

21. Pub. L. No. 102-240, 105 Stat. 1914 (1991).

22. See Rails-to-Trails Conservancy, ISTEA \& Trails: Enhancement Funding for Bicycling and Walking 2 (1996).

23. See Pub. L. No. 105-178, 112 Stat. 107 (1998).

24. See Glosemeyer v. United States, 45 Fed. Cl. 771 (Fed. C1. 2000) (challenging Katy Trail in Missouri); Grantwood Village v. United States, 45 Fed. Cl. 771 (Fed. Cl. 2000); Glosemeyer v. M-K-T RR Co., 685 F. Supp. 1108 (E.D. Mo. 1988), affd, 879 F.2d 316 (8th Cir. 1989).

25. See Seger v. United States, No. 4:99-CV-03056 (D. Neb. filed Feb. 15, 1999); see also infra part V.B (discussing shifting public use doctrine).

26. See Marcus, supra note 9; Ben Rand, Move to Create Trails Facing Legal Detours, COURIER J. (Louisville. KY), Aug. 11, 1995, 1 B.

27. 494 U.S. 1 (1990).

28. See id. at 11 .

29. See infra Part II.C. 


\section{B. Utility Licenses}

A new twist on the rail-trail cases is the recent attack on the use of rail corridors by utility companies to lay fiber-optic cable and fuel lines, to string electrical wires, and to install cellular transmitters. ${ }^{30}$ While the challenges are new, the uses are not; for over a century, the railroads have been granting rights to utility companies to string cables and run pipelines in their corridors. Ever since the telegraph was invented, rails and wires have moved together across the country, the railroad dependant on the telegraph for communication to upcoming stations and switches, and the telegraph dependant on the railroad's corridor for placement of its poles and wires. Controversy is also not new- the railroads and utilities have often battled each other over concurrent use rights in the corridors. For example, some railroads entered into exclusive license agreements with one telegraph company and were challenged by another to provide equal access. ${ }^{31}$ In others, some railroads abandoned corridors and removed their tracks and ties while continuing to demand royalties from utility licensors under contracts that may or may not have been formed prior to abandonment. ${ }^{32}$ The utilities have questioned the right of the railroads to continue to demand these royalties. Adjacent landowners have also disputed the right of the railroads to authorize utility and other third-party uses on their corridors.

What is new is the extent of change in the utility industries. Energy and telecommunications companies face new technologies, new markets, and new competition, all of which require increasingly intensive use of linear corridors. And this comes at a time when we have a national commitment to preserving rail corridors. Hence, utilities are hoping to piggyback on the railbanking policies to provide unbroken linear corridors

30. See, e.g., Hinshaw v. AT\&T Comm., No. IP98-1300CH/G (S.D. Ind. filed Sept. 18, 1998); Hallaba v. Worldcom, No. 98-CV-895-H (N.D. Okla. Mar. 31, 2000).

31. See Western Union Tel. Co. v. Postal Tel. Co., 217 F. 533 (9th Cir. 1914); Pacific Postal Tel. Cable Co. v. Western Union Tel. Co., 50 F. 493 (C.C.D. Wash. 1892).

32. See, e.g., Simacek v. York County Rural Pub. Power Dist., 370 N.W.2d 709 (Neb. 1985) (holding that valid utility license granted by railroad prior to its abandonment terminated upon the railroad's abandonment and removal of trackage): State Highway Comm'n v. Union Elec. Co., 148 S.W.2d 503 (Mo. 1941) (holding no right of railroad to grant easement to utility after abandonment, but did not allow utility's adverse possession claim). But see Champaign Nat'l Bank v. Illinois Power Co., 465 N.E.2d 1016 (Ill. App. Ct. 1984) (recognizing that a railroad could give a perpetual easement to a utility that would persist even after discontinuance by the railroad). 
with minimal transaction costs. It is far easier for a utility to negotiate with a single landowner for access to hundreds of miles of corridor rather than with individual landowners adjacent to the corridor. But in the rush to wire the nation, these fiber-optic companies are not as careful as they should be in determining whether the railroads have any property interests to sell if they have discontinued operations.

The new class action suits arise both from the intrusiveness of these new uses and from the increased visibility of the "property rights movement." ${ }^{33}$ Moreover, the utility companies are logical defendants; they have deeper pockets than most railroads, and they have been so hasty in wiring the country that they may have relied on tenuous property rights. But whether the railroad is authorizing utility use on its corridor or an interim trail use, these cases raise two legal issues: is the new use within the scope of the railroad use, and if not, who gets to pay the adjacent landowner for a taking of her property?

\section{The Legal Arguments Against Multiple Use and Conversion of Rail Corridors}

The plaintiffs in both the Rails-to-Trails and utility challenges argue that nineteenth century grants of land to various railroads across the country, if only acquired as easements, did not confer upon the railroads the power to convey licenses, subeasements, or leases to utility companies to lay pipelines or string cables or wires. ${ }^{34}$ Furthermore, the plaintiffs claim that the railroad easement terminates when railroad usage ends, and that the land must then be unencumbered..$^{35}$ Any use of that land for utilities or public trails after abandonment would thus constitute a taking because such a use imposes an additional burden on the servient land. ${ }^{36}$

33. See Montange, supra note 9, at 64-65; Lawrence P. Hanson, The Recycling of Railroad Rights-of-Way, 76 MiCH. B.J. 430 (1997); Stephen P. Miller, Eminent Domain-Preseault v. ICC: "Rails to Trails" Act-Section 8(d) Railbanking: An Authorized "Taking" of a Reversionary Interest?, 21 MEMPHIS ST. U. L. REV. 187 (1990); see also supra note 9 and articles cited therein.

34. See Amon, supra note 7, at A1; see also Hinshaw v. AT\&T, No. 29 D01 9705CP-000308 (Ind. Super. Ct. filed Nov. 6, 1996). This is not a new legal argument, since the courts have long evaluated whether railroads can authorize others to engage in activities in railroad corridors.

35. See infra Part $\mathrm{V}$ (discussing abandonment).

36. See, e.g., Glosemeyer v. United States, 45 Fed. Cl. 771 (Fed. Cl. 2000) (challenging Katy Trail); Hash v. United States, No. CV99-3245-MHW (D. Idaho filed Dec. 17, 1999) (challenging Weiser Trail); Swisher v. United States, No. 98-1352-KHV (D. Kan. filed Dec. 22, 1998) (certification overruled Sept. 24, 1999) (attempting to 
More specifically, class members allege that the scope of an easement for railroad purposes is not large enough or diverse enough to permit recreational trails, sub-surface pipes or cables, utility poles, or even the removal of tracks and ties. Any such use would signal the railroad's abandonment of its property rights, which would then revert to adjacent landowners. ${ }^{37}$ The plaintiffs argue further that the laws work a taking insofar as the federal railbanking provision explicitly preempts state property rights. ${ }^{38}$ And insofar as a railroad permits use of the corridor by recreational trail builders and users or by utility companies, that railroad is allegedly guilty of slander of title, and the utilities and trail users of trespass against the true owner. The plaintiffs do not distinguish between the railroad's rights to allow multiple uses while operating its services or after it has discontinued rail services. ${ }^{39}$

On one level, the cases are absurd. The railroads' rights to their corridor land are determined by state law precedents on deed interpretation, and ultimately rest on the language in the individual deed of each parcel. If the railroad owns fee simple title, it can authorize utility use or sell its parcel to a trail without reference to adjacent landowners. Thus, the resolution of disputes over their rights must begin with a quiet title analysis to determine exactly what interests the railroads hold. ${ }^{40}$ These class

certify a nationwide class); Seger v. United States, No. 4:99CV3056 (D. Neb. filed Feb. 15, 1999) (challenging Cowboy Trail); Schmitt v. United States, No. IP-99-C-1852-Y/F (S.D. Ind. filed Mar. 11 , 2000) (challenging Poseyville Trail): see also Montange, supra note 9 , at $69-72$.

37. See infra Part V.B (discussing public use of railroad right-of-way); see also N.Y. TiMES, Aug. 18, 1987, at Al4.

38. See 16 U.S.C. \& 1207(d) (1994); see also Preseault v. United States, 100 F.3d 1525, 1529, 1549-51 (Fed. Cir. 1996); Sheila K. Bryant, The Constitutionality of Railsto-Trails Conversions Under the National Trails Systems Act Amendments of 1983: Preseault v. ICC, 26 TULSA L.J. 295 (1990); Rita Cain, Unhappy Trails: Disputed Use of Railroad Rights-of-Way Under the National Trails System Act, 5 J. LAND USE \& ENVTL. L.J. 211 (1989); Thomas A. Duda, The Use of Discontinued Railroad Rights-ofWay as Recreational Hiking and Biking Trails: Does the National Trails System Act Sanction Takings?, 33 ST. LOUIS U. L.J. 205 (1988); Lawrence S. Lim, Walking the Line: Rails-to-Trails Conversions and Preseault v. Interstate Commerce Commission, 53 OHIO ST. L.J. 337 (1992). But see Montange, supra note 9; Roger M. Stahl, Smoke Along the Tracks: The Constitutionality of Converting Rails to Trails Under 16 U.S.C. $\$$ 1247(d)(1994), 16 WM. MITCHELLL. REV. 861 (1990).

39. See Hallaba v. Worldcom Network Services, Inc., No. 98-CV-895-H (N.D. Okla. Mar. 31, 2000) (denying certification of a class against Worldcom for all landowners adjacent to a rail corridor with Worldcom cable in it); Hinshaw v. AT\&T, No. 29 D01 9705-CP-000308 (Ind. Super. Ct. filed Nov. 6, 1996). See generally Amon, supra note 7 .

40. See Meighan v. United States Sprint Communications Co., No. 03A01-9308CV-00299, 1994 WL 529955, at *3-4 (Tenn. Ct. App. 'Sept. 30, 1994) (noting that 
actions ignore this reality. In addition, class counsel has traditionally not provided evidence that class members actually own any interest in the corridors. Various court documents baldly assert that all railroad corridors are held only as easements despite state case law to the contrary, and that all class members have title to the underlying fee even though most have deeds that explicitly exclude the rail corridor.

It is also crucial to consider the background property law of the past 150 years. Railroads have conveyed rights to use the rail corridors to utility companies since the mid-1800s because most federal and state charters explicitly linked railroad and telegraph use. Moreover, every state gave utilities eminent domain power to condemn easements, and that power of condemnation extended to the land in railroad corridors. ${ }^{41}$ Multiple use of these corridors was the rule, not the exception, regardless of whether the railroads owned their corridor land in fee simple or possessed only an easement over the land. ${ }^{42}$ The class action plaintiffs ignore this history.

Finally, these easements were not narrowly drawn. Railroad easements are often construed as general transportation easements, thus allowing multiple uses and conversion to highways, canals, and even bicycle trails. ${ }^{43}$ The general rule that an easement holder may grant subeasements when an easement is exclusive, as railroad easements are, would seem to resolve these cases before they even begin. ${ }^{44}$ Again, the class action

where class actions rest on individual deed interpretations, or land valuations, the class action mechanism is inappropriate).

41. See, e.g., Mass. St. 1833, ch. 187, $§ 1$ 1; 1849 ILL. Laws $\$ 2$; 1903 Fla. Laws ch. $5211 \S \S 1,3,7$ (codified as amended, F.S.A. \$73.161): Davis v. MCI Telecomm. Corp., 606 So. 2d 734, 737 (Fla. Dist. Ct. App. 1992).

42. See Hartford Fire Ins. Co. v. Chicago, Milwaukee \& St. Paul Ry. Co., 175 U.S. 91 (1899); Union Pac. R.R. Co. v. Chicago, Rock Island \& Pac. Ry. Co., 163 U.S. 564 (1896); Grand Trunk R.R. Co. v. Richardson. 91 U.S. 454, 468 (1875); Energy Transp. Sys., Inc. v. Union Pac. R.R. Co., 606 F.2d 934, 935-37 (10th Cir. 1979); United States v. Gates of the Mountains Lakeshore Homes, Inc., 732 F.2d 1411 (9th Cir. 1984). As a Florida District Court of Appeal noted:

A nexus between railroad and commercial telegraph facilities is found throughout the historical record. Acts of Congress in the 19th Century required railroads that had been granted right-of-way passage through United States lands to make their telegraph facilities broadly available for governmental, commercial and all other purposes. Likewise, the State of Florida by the Telegraph Act of 1903, ch. 5211, $\$ \$ 1,3,7$ (codified as FLA. STAT. \& 362.02 (West 1999)) expressly authorized telecommunications lines in railroad rights-of-way.

Davis v. MCI Telecomm. Corp., 606 So. 2d 734, 736 (Fla. Dist. Ct. App. 1992).

43. See infra Part V.B (discussing public use of the railroad right-of-way).

44. See Alan David Hegi, The Easement in Gross Revisited: Transferability and 
plaintiffs ignore unambiguous legal doctrines.

Nevertheless, these class action challenges to railroad corridor conversions have touched a sensitive spot. For the most part, there is little case law directly on point. Because the railbanking policy is relatively new, and fiber-optic technology is only a recent trend, the use of railbanking corridors for utility use is a novel situation. While there is a modest body of case law on multiple uses of railroad easements, that law is problematic because the nature of common law easements has changed to recognize the unique exclusivity rights of railroads. It is indeed odd to think that an easement holder may grant access that the owner of the underlying land cannot grant. In the cases that have addressed this issue, the states are split. ${ }^{45}$

Moreover, few cases directly address the problems raised by these class action plaintiffs. Issues of the railroads' subsurface rights in their easements have been addressed most frequently in cases regarding mineral rights, which have uniformly been decided against railroads. ${ }^{46}$ Analyses of airspace rights have typically addressed whether electric line or telephone line use causes aesthetic injuries to the servient landowner. ${ }^{47}$ For the most part, utility lines, sewer lines, oil and gas pipelines, and drainage systems have all coexisted peacefully in railroad corridors with remarkably little litigation over property rights.

These cases thus address questions heretofore unasked. They will direct the future growth of the utility industry and have serious implications for environmental and growth management controls as well. Increasing urban sprawl makes it difficult for utility companies to provide vital utility services; central processing plants must be connected to outlying areas. ${ }^{48}$ But the

Divisibility Since 1945. 39 VAND. L. REV. 109 (1986); see also infra Part III.B (discussing exclusivity).

45. Compare Energy Transp. Sys. Inc. v. Union Pac. R.R. Co., 606 F.2d 934, 937 (10th Cir. 1979), and Energy Transp. Sys. Inc. v. Union Pac. R.R. Co., 619 F.2d 696 (8th Cir. 1980), with Davis v. MCI Telecomm. Corp.. 606 So. 2d 734, 738 (Fla. Dist. Ct. App. 1992) (authorizing utility's use from grant of right-of-way by railroad), and Mellon v. Southern Pac. Transp. Co., 750 F. Supp. 226, 230-31 (W.D. Tex. 1990) (same).

46. See, e.g., United States v. Union Pac. R.R. Co., 353 U.S. 112, 120 (1957); David Ebner, Mineral Ownership Beneath Railroad Rights-of-Way, 31 CoLo. MINERAL L. INST. \$ 17 1985. For state cases, see, for example, Consumers' Gas Trust Co. v. American Plate Glass Co.. 68 N.E. 1020 (Ind. 1903); Brookbank v. Benedum-Trees Oil Co., 131 A.2d 103 (Pa. 1957); Queen Mill \& Elevator Co. v. Sanders, 370 P.2d 419 (Kan. 1962).

47. See infra Part III.D.2 (discussing height); Unsightliness of Powerline or Other Wire or Related Structure, as Element of Damages in Easement Condemnation Proceeding, 97 A.L.R.3d 587 (1996).

48. See generally Wilner, supra note 5 . 
rail corridors that have always provided convenient locations for placement of utilities are being dismantled and broken up by railroad reorganization even as they become ever more essential to the utility companies. ${ }^{49}$ It is increasingly critical to know whether states will protect railroad rights, even if only in easements, to provide utility corridors to the public. ${ }^{50}$

These cases also raise vital questions about future transportation patterns. Many areas already feel the burden of unrestrained and unplanned growth. cities are on the EPA blacklist for excessive violations of air quality levels, most predominantly caused by excessive automobile use. ${ }^{51}$ Preserving rail corridors for alternative transportation venues is not only a wise policy, but it will become critical in the next few decades. Railbanking is therefore an important transportation policy. Many opponents are skeptical; they believe that once a beautiful linear park is built on a corridor, no trains will ever run there again. But the Grants Trail in Missouri is currently being reactivated as a rail line by the STB. Ultimately, whether the trains are brought back in or trails are allowed to remain on these corridors, vital public transportation needs can be met by recycling lands acquired for public use with public money and through public eminent domain powers. But it is the public that is most noticeably absent from these lawsuits.

The plaintiffs in these suits also fail to recognize the danger they are creating for themselves. Weakening the property rights of the railroads and utilities by misreading deeds or by creating presumptions against the railroads may benefit local landowners in these suits. But such tactics also weaken the property rights of regular, private citizens; such flawed legal interpretation works against the private easement holder trying to get utilities from the public highway to his or her house. In the long run, those who support property rights may rue, rather than celebrate, these lawsuits.

Plainly, none of these cases can or should proceed without a clearer understanding of the history and legal structure of rail

49. See generally id.

50. Every state has legislation dealing in some way with abandoned rail corridors, trail conversions, or utility uses along rail lines. See, e.g., IOWA CODE ANN. § 327G.77 (West 1997); WASH. REv. CODE $\$ 64.04 .180$ (1999); CaL. STS. \& High. Code § 2540-2549 (West 1997); N.H. REv. STAT. ANN. § 228:60-a (1999).

51. Finding of Significant Contribution and Rulemaking for Certain States in the Ozone Transport Assessment group Region for Purposes of Reducing Regional Transport of Ozone, 63 Fed. Reg. 57,356 (1998) (to be codified at 40 C.F.R. pts. 51 , $72,75,96)$. 
charter while the engineers were already surveying the line and laying the track. The law could not keep up with the heady optimism of expansion or the shattered expectations of collapsed lines. Much of the law developed after problems evolved, and it was often narrowly tailored to the circumstances at hand. But with the benefit of a century and a half, we can begin to identify patterns and practices and evaluate them for their continuing vitality.

Determining the property rights in any one railroad line and its adjoining parcels of land may require an extensive title search to locate the original granting documents and a thorough knowledge of nineteenth century case law to determine the exact nature of the railroad's property interests. The following brief history, however, identifies the most common acquisition practices and relevant property interests for the typical railroad.

\section{A. 1830-1860: The Railroads Herald a Bright Future}

The completion in $\mathbf{1 8 2 5}$ of the Erie Canal demonstrated the economic benefits of linking the agricultural and industrial inlands to coastal waterways, and drove every state to seek federal aid in constructing transportation corridors. $^{54} \mathrm{~A}$ tremendous burst of internal improvements occurred in the mid1830 s as a series of canals was built to link the states between the Mississippi River and the Atlantic Ocean. ${ }^{55}$ These canals were beneficiaries of an innovative federal program in which large grants of federally owned land would be conveyed to the canal company or to the state for sale to the general public. The canal company thereby received necessary funds from the land sales for construction, and the proximity of local transportation corridors resulted in significant appreciation in the value of the land retained by the federal government. ${ }^{56}$ Thus, although the land was given away, the economic benefit to the retained lands easily compensated for the loss, and the government could subsidize internal improvements without doing the work itself. These grants also included unrestricted right-of-way access to the strip of any public land on which the canal was constructed. Although the railroads were first built in the $1830 \mathrm{~s}$, it was 1850 before a railroad was a recipient of this generous government

54. See Paul Gates, History of Public land law Development 343 (1983).

55. See id.

56. See id. at 341-86. See generally LlOYd MERCER, RAILROADS AND LAND GRANT Policy 3-15 (1982) (explaining the history of the early subsidies and the predictions for adequate return on the government's investments). 
corridors. In the next Part, we survey the means by which railroads obtained their rail corridors and examine the various property rights the railroads generally have in those lands.

II

\section{THE HISTORY OF RAILROAD LAND ACQUISITION PRACTICES}

Tracing the precise landholdings of all the railroads in the United States would be nearly impossible; ${ }^{52}$ nineteenth century railroad land acquisition was complex and controversial, and little has been written on the property rights of and the relationship between the railroads and the landowners adjacent to their corridors. ${ }^{53}$ Yet to understand the law of the railroads, one must understand their history. Railroads received tremendous government subsidies in the form of federal land grants, government bonds, state land grants, tax abatements, favorable legislation, and eminent domain powers. Private capital also invested heavily in the railroads, speeding expansion and development in the midwest and western states far beyond the rate envisioned by politicians and homesteaders. The enthusiasm for the railroads created a climate in which railroad moguls and state politicians might be finalizing the terms of a

52. Given the large, interstate railroad companies that have absorbed some lines and abandoned others, and the countless short-line and branch-line railroads serving shippers across the country, it would be impossible to trace the precise landholdings of all the railroads in this country. The Interstate Commerce Commission came closest when, under the federal 1913 Valuation Act, it attempted to inventory and value all property of the nation's rail carriers. Act to Regulate Commerce of 1913, ch. 92, 37 Stat. 701. See generally James D. Jennings, Railroad Right of Way Appraisal, RIGHT OF WAY, Oct. 1984. at 4. It took over two decades and hundreds of millions of dollars to complete and produced a series of valuation maps of the railroads' property holdings. But even these maps are unreliable because some railroads have not kept them up to date and even when the railroads have been diligent, the map may lack crucial information. See id. at 5.

53. The majority of railroad histories are concerned with regulation, expansion and contraction of services, or are individual biographies of the great railroad men. See, e.g., MAURY Klein, The LifE and Legend of JAY GoUld (1986); John F. STOVer, History OF THE BALTIMORE AND OHIO RAILROAD (1987): JOHN HOYT WilliaMS. A GREAT AND SHINING ROAD: THE EPIC STORY OF THE TRANSCONTINENTAL RAILROAD (1988); JAMES AFTHUR WARD \& J. EDGar THOMSON: MASTER OF THE PENNSYLVANIA (1980); JOHN D. FORBES, J.P. MORGAN, JR.: 1867-1943 (1981). Probably the most comprehensive and informative studies are the ENCYCLOPEDIA OF AMERICAN BUSINESS HISTORY AND BIOGRAPHY: Vol. 1 RAILROADS IN THE NINETEENTH CENTURY (Robert L. Frey ed., 1988), and Vol. 2 Railroads in the AGE of Regulation, 1900-1980 (Keith L. Bryant Jr. ed., 1988). For a good history of the early decades of rallroad development, see JOHN $F$. STOVER, IRON ROAD TO THE WEST: AMERICAN RAILROADS IN THE 1850S (1978). And for an excellent study of the linkages between railroads and telegraphs, see ALBRO MARTIN, RaIlROADS TRIUMPhaNT: THE GROWTH, Rejection, and REBIRTH OF a VITAL AMERICAN FORCE (1992). 
subsidy. ${ }^{57}$

But the issue of federal financial aid raised some sticky legal questions. $^{58}$ Although canals and railroads are private corporations, they provided great public benefits. Many believed the railroads deserved to receive state and federal aid through grants of land, outright money grants, or loans to pay for land acquisition and road construction. ${ }^{59}$ But critics asserted that the federal government lacked the power under the Constitution to turn federal lands over to private ownership for internal improvements, even though no one questioned Congress's power to authorize construction of these roads directly. ${ }^{60}$ Consequently, different administrations had different commitments to using federal lands in the development of privately held railroads and canals. ${ }^{61}$ But when the federal government retreated during more conservative administrations, the states often stepped in to grant similar land rights to the railroads and to give them eminent domain powers when they required privately owned land. These grants of eminent domain powers raised questions, however, about whether these projects were a legitimate public use if they

57. See GATES, supra note 54, at 358; IsAaC REDFIELd, A PRACTICAL TREATISE UPON THE LAW OF RAILWAYS 3 (2d ed. 1858). See generally MERCER, supra note 56. In 1850. following the tradition of the canal grants, the first grant of land was given to a railroad, in addition to the traditional rights-of-way across public lands that had characterized railroad aid in the two preceding decades. See Act of Sept. 20, 1850 , ch. 61, 9 Stat. 466; see also PaUl Wallace Gates, ThE Illinois Central Railroad and ITS COLONIZATION WORKS (1934); THOMAS E. ROOT, Railroad Land Grants: From Canals to Transcontinentals, 1987 A.B.A. SEC. NAT. RESOURCES L. This grant, originally given to the state of Illinois but later expanded, was to link Dubuque, Iowa: Chicago, Illinois; and Mobile, Alabama. Because Illinois was prohibited by its constitution from building the railroad itself, it turned the land grant over to the Illinois Central Railroad. See GaTES, IllinoIs CENTRAL, suprar see also HowARD GRAY BROWNSON. History of THE IllinOIS CENTRAL RaIlROAD to 1870, IllinoIs STUdies IN THE SOCIAL SCIENCES, Vol. IV, No. 3 (1915). When the other states did the same, the first major north-south railway line was built. Mississippi and Alabama conveyed their land rights to the Mobile and Ohio Railroad, but that left the states of Kentucky and Tennessee without grants because there was no publicly held land. The Mobile and Ohio Railroad, therefore, had to acquire the 164 miles of land needed to traverse those two states without any federal or state aid. See GATES, supra note 54, at 35960 .

58. See generally RooT, supra note 57 (explaining land rights and mineral rights cases).

59. See generally GATES, supra note 54; see also Frank N. Wilner, History and Evolution of Railroad Land Grants, 48 ICC PRACTICE J. 687 (1981). Loans were used to buy land and pay for the construction of the new railroad line.

60. See GATES, supra note $\mathbf{5 4}$, at $\mathbf{3 5 2}$.

61. John Quincy Adams' administration was far more forthcoming with financial assistance than the successive administration of Andrew Jackson. See GATES, supra note 54, at 352; see also Robert W. Swenson, Railroad Land Grants: A Chapter in Public Land Law, 5 UTAH L. REV. 456 (1953). 
were to be privately owned. ${ }^{62}$ In the end, these issues were resolved in favor of the railroads and canals who uniformly received eminent domain powers from the federal government or the states to facilitate land acquisition in the areas where they did not receive the land directly from the federal or state governments; railroads and canals were given, at the very least, rights-of-way for passage over all public lands. ${ }^{63}$

Because of tremendous population growth in the 1840s, and the general public clamor to speed railroad expansion to make more undeveloped lands accessible, Congress passed a general law in 1852 giving 100-foot rights-of-way to railroads through all public lands and authorizing the railroads to remove stone, earth, and timber from adjacent public lands. ${ }^{64}$ For the next decade, the midwestern and southern states scrambled for federal land grants to aid construction of railroads. Grants to these states consisted of over 27.8 million acres for 50 railroads with a total length of 8,647 miles. ${ }^{65}$

Prompted by the 1852 federal right-of-way legislation, most states enacted general railroad legislation that clarified the rights each chartered railroad company would possess in the property it acquired. ${ }^{66}$ Between 1850 and 1900 , every state that enacted railroad legislation gave the railroads eminent domain powers. The tremendous public benefit provided by these new roads easily justified the legislative grant of limited sovereign powers. ${ }^{67}$

62. See GATES, supra note 54, at 360-62; see also MERCER, supra note 56, at 145 (giving an economic rather than a legal analysis of the efficacy of the land grants, concluding that only some of the transcontinental railroads were economically rational).

63. For statutes that provided for the sale of public lands to railroads, see, for example, Act of Aug. 4, 1892, ch. 80, 10 Stat. 28; Mo. REV. STAT. \$ 388.380 (1853); N.Y. LAW $\S 25$ (McKinney 1852).

64. See Act of Aug. 4, 1852, ch. 80, 10 Stat. 28.

65. See GATES, supra note 54 , at 362 .

66. See W.P. GregG \& BENJAMin Pond, The Railroad Laws and Charters of the U.S. (Boston: Little \& Brown, 1851) giving all railroad charters from most of the eastern states, including Maine, Connecticut, Rhode Island, Vermont, New Hampshire, and Massachusetts.

67. For an excellent survey of the economic benefits of the early railroads, see J.L. Ringwalt, DEvElopment OF TRANSPORTATION SYSTEMS IN THE UNITED STATES 106-55 (1888).

There is no doubt that the cash value of the property of the entire country has been advanced by railways to a sum that very greatly exceeds the cost of their construction, and it has unfortunately happened that such gains of land owners and citizens have often occurred on lines that were very unprofitable to stockholders. In other words, an expenditure of a few billions of dollars for railways has benefited other persons, who have made no important investments in the securities of such enterprises, to the extent of many more billions of dollars. 
At a time when most states had insufficient funds for extensive public roads and canal systems, the railroads' offer to invest private capital in a massive public project could hardly be refused. For a long time, eastern and midwestern states asked the railroad developers few questions as they handed over the power to take private land, opened their court systems to condemnation proceedings, provided tax incentives to particular lines, and sometimes participated in the construction by donating public lands for depots and/or facilitating financing through government bonds and loans. ${ }^{68}$ Between 1845 and 1860 , state governments borrowed over $\$ 90$ million to finance railroad construction, and at least one state, Illinois, went bankrupt as a result. ${ }^{69}$

Land that was already held in private hands had to be obtained directly from the owners when the railroad's route could not stay on public lands. ${ }^{70}$ The first railroads to be built in the east were intrastate lines that were built under individual charters granted to each railroad from the respective state legislature. ${ }^{71}$ Once the charter was obtained, the railroads would send out surveyors to mark the route and land agents to acquire deeds from the individual landowners. ${ }^{72}$ In some circumstances, the benefits that would accrue to the landowner from immediate

Id. at 106-07. Additionally, the costs of overland transportation were dramatically reduced by the construction of railroads. See id. at 154-55. A rather quantitative economic analysis of the land grants, with 20-20 hindsight, comes from MERCER, supra note 56 , at 144 . Mercer concludes that, on all but one railroad line. the transcontinental land grants were rational in terms of economic efficiency. See id. at 145.

68. See 2 ENCYCLOPEDIA OF AMERICAN BUSINESS HISTORY AND BIOGRAPHY, supra note 53, at xiv (explaining how state and local governments granted liberal railroad charters, supplied money and credit, and some even built the lines themselves). I also saw evidence of this in many of the cases I examined in which tax incentives and government bonds were used to help induce a railroad to locate to a particular city. See, e.g., Schneck v. City of Jeffersonville, 52 N.E. 212 (Ind. 1898); Chicago \& Calumet Terminal Ry. Co. v. Whiting Hammond \& E. Chicago St. Ry. Co., 38 N.E. 604 (Ind. 1894); Nelson v. Haywood County, 11 S.W. 885 (Tenn. 1889).

69. See 2 ENCYCLOPEDIA OF AMERICAN BUSINESS HISTORY AND BIOGRAPHY, supra note 53 , at xiv.

70. For instance, when the Mobile and Ohio Railroad was attempting to build its line, it had to purchase land directly from private landowners in Kentucky and Tennessee because there were no public lands in those states. See supra note 57; GATES, supra note 54 , at 359 .

71. See Gregg \& POND, supra note 66; see also Redfield, supra note 57, at XX.

72. Sometimes the agents purchased the land in trust for the railroad and later conveyed the entire corridor to the railroad in a single transaction, and sometimes they negotiated for the land, prepared the documents in conjunction with the railroad's legal departments, and then went back out with the checks and the prepared deeds to finalize the land transaction. 
access to rail services and higher land values was sufficient consideration to convince the landowner to make an outright grant of corridor land to the railroad..$^{73}$ In other cases, the necessary land was purchased from the landowner and a deed given. When a landowner absolutely refused to give up any of his or her land, eminent domain powers were necessary to allow the

73. See 2 ENCYCLOPEDIA OF AMERICAN BUSINESS HISTORY AND BIOGRAPHY, supra note 53, at xiii (explaining that "American people welcomed the railroad with unbounded enthusiasm and invested their savings and supported the promoters who built the lines across the country."). The sometimes nominal monetary consideration is often cited by courts as evidence that the railroads did not acquire fee simple absolute to the land because the only consideration cited was the benefit that would accrue to the landowner from construction of the road. For instance, in Tompkins $v$. Atlantic Coast Line R.R. Co., 79 S.E.2d 41, 42-45 (Ga. App. 1953), the court interpreted a deed stating, "In consideration of the consequent enhanced value of my adjoining land and of the benefit to the community by the construction of the ... Railroad ... I, ... do hereby sell, transfer and convey in fee simple unto the ... Railroad" to convey only an easement, stating, against all rules of logic and deed interpretation, that the "words 'in fee simple' are descriptive of the extent of duration of the enjoyment of the easement conveyed." Id. Although this court did not rely on the nominal consideration for its decision, many courts have. Such an interpretation, however, ignores the fact that in certain cases, rail access directly from a landowner's parcel more than doubled the value of the remaining land. See RINGWALT, supra note 67, at 106-07. For a related discussion, see Mason Brayman's paper for the Illinois Central Railroad Company, explaining that:

It has heretofore been, and is yet to be, a leading object to obtain from all persons owning, or having interest in, lands to be affected by the location and construction of the Road, voluntary relinquishment of the privileges necessary to our operations. It is believed that, in a majority of cases, property holders, actuated by a generous desire to aid in securing the important public benefits expected to be derived from the construction of such a work, and finding their property benefited by fencing, drainage, and improved facilities of transportation, will freely donate the privileges desired, or relinquish for merely nominal sums. In cases of spectal damage to buildings and improvements, or otherwise, a property compensation is to be made; it being desirable to deal with parties interested, in a just and liberal spirit, so as to secure, without resort to the legal means provided, a satisfactory adjustment of every question which may arise. In all intercourse with the people along the line- in all negotiations for the privileges which it may be necessary to acquire, and in resorting to the legal mode of acquiring them, a careful regard for the rights and feelings, and even prejudices (should such be encountered) of those whose interests are to be affected, is to be observed. The dictates of sound policy, no less than of justice, counsel such a course as will secure the good will and co-operation of the people. so that the company may arrive at the completion of its great work, so fruitful of mutual advantages, so prolific of public benefits, free from those exasperations and prejudices which too often such enterprises.

Mason Brayman, Instructions to Agents Engaged in Securing the Right of Way, etc. (Mar. 22, 1852) (Mason Brayman Papers at the Chicago Historical Society) (on file with author). Although not all land agents were as solicitous of the feelings and prejudices of landowners, the railroads quite obviously knew they were providing a great benefit to an area. 
railroads to complete their line acquisition. ${ }^{74}$

On some lines, the railroad would enter into contracts to purchase the corridor land if and when the line was built. Occasionally, neither the landowner nor the railroad would finalize the land conveyance even after construction of the line, and the only evidence to determine what was conveyed were these contracts. ${ }^{75}$ In other cases, the landowner might be unavailable and the railroad, knowing it had eminent domain powers, would simply construct the line and wait until the landowner complained before negotiating the transfer. $^{76}$ In addition, if the landowner sold his remaining land without having been paid by the railroad for the amount taken, the buyer would not have a claim against the railroad; only the original landowner would retain the claim because the buyer took the land with notice that it was encumbered by a rail servitude. ${ }^{77}$ Even a single one or two mile stretch of corridor might involve landowner negotiations of all these different types.

The greatest legacy of this period of railroad development is the incredible legal quagmire that was created by the haste of railroad entrepreneurs and the haphazard pattern of state authorization and oversight. Railroads might have been operating for decades before land issues were settled. Other lines might have been chartered and the land purchased, but never built. Competition or lack of funds often doomed a line after considerable financial outlays. A subsequent company would then attempt to purchase the defunct line's assets, including corridor land, years later. But what most characterizes this

74. If condemnation was required, the railroad instituted condemnation proceedings and the courts would determine the amount of compensation necessary through appraisals of three people in the community. See, e.g., ConN. GEN. STAT. § 13b-256 (1999) (requiring appointment of three appraisers); N.Y. Law \$\$ 13-18 (McKinney 1852) (requiring five local men of the neighborhood be appointed).

75. The contracts have been held to constitute a transfer of property interests, even in the absence of a deed. See Burrow v. Terre Haute \& L. R. Co., 8 N.E. 167 (Ind. 1886).

76. See Evansville \& T.H.R. Co. v. Nye, 15 N.E. 261 (Ind. 1888) (holding that railroad acquired land by adverse possession when the railroad entered openly and notoriously for 25 years before suit was brought).

77. These damage actions were considered personal and did not pass with the land. See, e.g., id. at 265-66; Indiana, Bloomington \& W. Ry. Co. v. McBroom, 15 N.E. 831 (Ind. 1888); Paul v. Connersville \& Newcastle Junction R.R. Co., 51 Ind. 527 (Ind. 1875). Many states do not allow the transfer of rights of re-entry or possibilities of reversion as this would permit a grantor to avoid the workings of the rule against perpetuities. See Cunningham, Stoebuck \& WhitMan, THE LaW OF PROPERTY 153 n.28 (2d ed. 1993). The result, however, is that successors in interest to land encumbered by railroad use would have few remedies, which is quite reasonable in light of that fact that they generally took the land with notice of the encumbrance. 
period is the generous state and federal aid, both legislative and financial, that made possible a network of over 10,000 miles of transportation corridors east of the Mississippi.

\section{B. 1860-1871: Reckless Expansion}

In 1860 , the West remained a great, uncharted frontier, but the California gold rush created an increasing demand to construct a transcontinental railroad linking the Pacific Ocean with the rest of the country. Most of the 1850s had been spent debating the cost, feasibility, desirability, and location of a potential road. $^{78}$ In 1862 , with the Civil War imposing tremendous strain on the nation's railroads, Congress passed a massive land grant to the Union Pacific and Central Pacific railroads to construct lines east from San Francisco, California, and west from Omaha, Nebraska, to meet somewhere in the middle. ${ }^{79}$ This grant was followed in 1864 by the Northern Pacific grant to link Lake Superior to Puget Sound; ${ }^{80}$ in 1866 by the Southern Pacific grant to link Springfield, Missouri, to southern California; ${ }^{81}$ and in 1871 by the Texas Pacific Railroad grant to link El Paso, Texas, to San Diego, California. ${ }^{82}$

All in all, between 100 and 110 million acres of federal land were promised to the transcontinental railroads between 1862 and 1871. Federal land grants to states for railroads in the midwest and southern states also increased during the 1860 s. $^{83}$ Nationally, approximately 130 million acres were granted to the states or directly to the railroads from federally held public lands, a large percentage of which is still retained by the

78. See GATES, supra note 54 , at $362-68$.

79. Pacific Railroad Act of July 1, 1862, ch. 120, 12 Stat. 489, amended by ch. 216,13 Stat. 356 (1864). The statute authorized a capitalization of $\$ 100$ million from stock subscriptions, authorized loans of almost $\$ 100,000$ per mile in 30-year government bonds for construction, and granted the railroad a 400-foot right-of-way through the public lands and 10 odd numbered sections of land for each mile of road constructed. This amounted to a checkerboard belt of land extending five, ten, or twenty miles in width on both sides of the road.

80. Act of July 2,1864 , ch. 217,13 Stat. 365 , amended by Resolution, 16 Stat. $378(1870)$.

81. The Southern Pacific grant was actually made to the Atlantic and Pacific Railroad, which went bankrupt in 1875 and construction was picked up by a variety of other railroads, including the Atcheson, Topeka, the St. Louis and Atlantic \& Pacific Railroad Company Incorporated. See Act of July 27, 1866, ch. 278, 14 Stat. 292.

82. Act of Mar. 3, 1871, ch. 122, 16 Stat. 573.

83. See Gates, supta note 54, at 384-85; Frank WILNER, RaIlroad LAND Grants: PAID IN FULL, U.S. OFFICE OF INFORMATION AND PUBLIC AFFAIRS (1984). 
railroads to this day. ${ }^{84}$

Tension between the railroads and the public arose quickly in the western states. Many westerners wanted railroads and yet still wanted inexpensive land available for development. As the railroads eventually took title to all their lands, the land available for homesteading was greatly reduced if the railroads did not turn the land over for public use quickly enough. ${ }^{85}$ Attitudes turned from "warm friendship to outright hostility" when westerners found that the railroads were not especially prompt in bringing their lands to market. ${ }^{86}$ When western settlers joined the Grangers, ${ }^{87}$ who were fighting for federal regulation of the railroads, the tide of public opinion finally shifted from welcome encouragement to suspicion and outright hostility. ${ }^{88}$ The 1871 Texas Pacific was to be the last federal grant to the railroads of lands west of the Mississippi.

The 1860 s and 1870 s brought tremendous competition among the non-land-grant railroads in the eastern and midwestern states. ${ }^{89}$ Labor strikes in the 1870 s also caused great strains on shippers. ${ }^{90}$ With greater competition came cutthroat railroad practices that ultimately hurt the shipping and traveling public. Because some carriers would provide rebates to certain shippers and not to others, the shippers naturally complained. As a result, groups such as the Grangers began to put pressure on state and federal representatives to cut back on the railroads' privileges. Even many railroad executives favored federal regulation because individual railroads would routinely undermine local pooling and apportionment agreements. ${ }^{91}$ By 1870, individual states began to respond by imposing greater liabilities on railroads if they failed, and stringent requirements

84. See generally WILNER, supra note 83 .

85. See GATES, supra note 54 , at 380 .

86. Id. at 380 .

87. The Grangers were a coalition of farming interests in the midwest who were frustrated by the discriminatory pricing and unreliable schedules of the highly competitive railroads. See id. at 380-81; see also SOLON BUCK, THE GRANGER MOVEMENT 9 (1913); GABRIEL KOLKO, RAILROAD AND REGULATION 1877-1916, 127-54 (1965). The Grangers were also responsible for a variety of state railroad regulatory schemes that were upheld by the Supreme Court in Munn v. Mlinois, 94 U.S. 113 (1876).

88. See GATES, supra note 54, at 380-81: Swenson, supra note 60 , at 459 .

89. For an excellent history of the decade before federal regulation and the cutthroat competition between railroads, see Kolko, supra note 87, at 7-29.

90. See 2 ENCYCLOPEDIA OF AMERICAN BUSINESS HISTORY AND BIOGRAPHY, supra note 53, at xvii.

91. See Kolko, supra note 87 , at $\mathbf{2 6 - 4 4}$. 
for discontinuation and abandonment of lines. ${ }^{92}$

\section{Post-1871: The Glow Fades}

The overall result of the explosive growth and rapid contraction of rail services was a profound shift in attitudes toward the railroads beginning in the 1870 s. In some states, this shift did not become fully entrenched until the early 1900s. But it eventually happened in all states- when the great rewards promised by the railroads failed to materialize, landowners, politicians, and investors began to view the railroads as government pork at the expense of taxpayers. ${ }^{93}$ The states were nearly uniform in cutting back on the railroads' powers of eminent domain starting in the 1880 s and ending in the 1920 s. $^{94}$ Some states, like Indiana, specifically amended their railroad legislation to no longer allow the railroads to acquire by condemnation fee simple title to the corridor land, but merely easements, though the ability of the railroad to purchase fee simple title remained intact. ${ }^{95}$ Other states imposed limits on the railroads' ability to acquire title by adverse possession or to purchase land in fee simple. ${ }^{96}$ And still other states left the land acquisition powers intact but tightened up their laws on

92. Even before passage of federal regulations imposing rate limits and standard employee practices, certain states had begun to grow disenchanted with the railroads and had reduced their powers under state legislation. For instance, Indiana reduced the railroads' authority to condemn corridor land to easements rather than fee simple in 1905. See 1905 Ind. Acts ch. 48 \& $\mathrm{l}$. Illinois also amended its eminent domain statute to remove the language that the railroad will be "seized in fee." See 1849 Ill. Laws $\$ 22$, as amended by 1871-72 Ill. Laws $\$ 17$.

93. 2 ENCYCLOPEDIA OF AMERICAN BUSINESS HISTORY AND BIOGRAPHY, supra note 53, at xix (explaining that between 1873 and 1897 one-third of U.S. railroad mileage was in receivership and reorganized by banking moguls such as J.P. Morgan). By 1900 , seven big financiers owned nearly two-thirds of railroad mileage, resulting in harsh criticism and passage in 1906 of the Hepburn Act, ch. 3591, 34 Stat. 584 (1906). See Kolko, supra note 87, at 127-54.

94. In Ohio, for example, a railroad could condemn a fee simple absolute. See Pittsburgh \& W. Ry. Co. v. Garlick, 20 Ohio C.C. 561 (1900). But by 1946, a railroad could only acquire an easement by condemnation. See Hinman v. Barnes, 66 N.E.2d 911 (Ohio 1946). And in New York, a railroad acquired a base fee or terminable fee in People ex rel. Bryan v. State Bd. of Tax Comm'rs, 127 N.Y.S. 858 (N.Y. App. Div. 1911), but could only obtain an easement seven years later in Mechanicuille \& Ft. Edward R.R. Co. v. Fitchburg Ry. Co., 170 N.Y.S. 476 (N.Y. Sup. Ct. 1918), aff'd, 128 N.Y.S. 904 (N.Y. App. Div. 1919).

95. See IND. CODE ANN. \$ 32-5-12-11 (Michie 1999); Texas Co. v. State ex rel. Coryell, 180 P.2d 631 (Okla. 1947) (holding that territorial statute limited power of railroad to take by eminent domain any interest greater than an easement).

96. See, e.g., Meyer v. Pittsburgh, Cincinnati, Chicago, \& St. Louis Ry. Co., 113 N.E. 443 (Ind. Ct. App. 1916); Gulf Colorado \& Santa Fe Ry. Co. v. Brandenberg, 167 S.W. 170 (Tex. Ct. App. 1914). 
abandonment so that land held as easements would be extinguished if the railroad did not continue to operate and maintain the corridors. ${ }^{97}$

While we are not concerned here with the 1887 federal regulation of interstate carriers and shippers, ${ }^{98}$ the increased control by both state and federal governments, as well as more stringent judicial scrutiny, hit the railroads at a time when they were already reeling from vicious competition among themselves and negative public opinion. The media and later historians perpetuated the image of the railroads as a governmentsubsidized monopoly. As one historian described it:

Gradually, as knowledge of how railroads were being financed permeated to the general public, the whole affair of railroad promotion, both the honest and the otherwise, was lumped together to make a gigantic and national scandal which has ever since been a milepost in many American history books, many of which have showed maps displaying thick, sinister lines of black indicating the proportion of the public domain that had been granted to railroads. Historians revolted at the exposes of the sharp railroad promoters, wrote angry texts that for the past sixty years have been accepted as gospel in our schools and colleges. Because the historians were angry and because also they really did have reason for anger, many a textbook has been unfair to the railroads and to the administrations that made the land grants. ${ }^{99}$

With the Hepburn Act $^{100}$ and increasing federal regulations in the first decades of the twentieth century, the railroads were unable to recover from the additional competition of trucking after the Great Depression. ${ }^{101}$ The last half of this century, therefore, has been spent trying to save the railroads from the effects of political and legal disfavor. ${ }^{102}$

The history of the railroads is a fascinating study in the

97. This trend can be seen in judicial decisions finding no abandonment after one year under a set a facts that would give rise to a finding of abandonment twenty years later. Compare Durfee v. Peoria Decatur \& Evansville Ry. Co., 30 N.E. 686 (IIl. 1892), with Chicago \& E. Illinois R.R. Co. v. Clapp, 66 N.E. 223 (Ill. 1903); compare Barlow v. Chicago Rock Island \& Pac. R.R. Co., 29 Iowa 276 (Iowa 1870), with Vandewater v. Chicago Rock Island \& Pac. R.R. Co., 153 N.W. 190 (Iowa 1915).

98. Interstate Commerce Clause Regulations Act, Feb. 4, 1887, ch. 104, 24 Stat. 379 (1887).

99. STUART HOLLBROOK, THE STORY OF AMERICAN RAILROADS 156 (1947).

100. Act of 1906, ch. 3591, 34 Stat. 584.

101. See 2 ENCYCLOPEDIA OF AMERICAN BUSINESS HISTORY AND BIOGRAPHY, supra note 53 , at xxi-xxii.

102. See generally RaILROAD REvitalization AND REgulatoRy REFoRM (MacAvoy \& Snow eds., 1977). 
failures and successes of capitalism and laissez-faire economics. ${ }^{103}$ By connecting various population groups in the nation, the railroads had a tremendous effect on the cultural diversity of this country. ${ }^{104}$ It should come as no surprise, therefore, that land acquisition practices and the corresponding property laws dealing with state and federal regulation would be complex and variable. ${ }^{105}$ Case law affecting railroad property rights seems to reflect a fairly steady decline since the 1870 s in the judicial protection of the railroads' property rights and interests. Although much of that animosity may have been justified at the turn of the century, now is the opportunity to rethink the role of the railroads in the next century of land use development and regulation.

\section{What the Railroads Own}

Railroads most commonly acquired property through condemnation, private grant, state or federal grant, or prescription. ${ }^{106}$ In principle, the railroads could acquire at least six different types of property interests: a fee simple absolute, a fee simple subject to a condition subsequent (with a right of reentry in the grantor), a fee simple determinable (with a possibility of reverter in the grantor), a perpetual or unlimited easement, a

103. As Paul GATES states:

It was the land grants that persuaded capitalists to invest in securities of the railroads and enabled the railroads to advance far beyond the zone of settlement, to be the true pioneers in opening up new areas to growth. That some were built too far in advance of need must be conceded, especially in the light of their subsequent bankruptcy. The strenuous immigration promotion campaigns undertaken by the land grant railroads were felt all over Europe and in the older states. The results are to be seen in the rapid settlement of the West which, it had been earlier thought, would take one or two centuries. By 1890, the Superintendent of the Census could say: "The Frontier is gone." The rush of new states into the Union in 1876,1889 , $1890,1896,1907,1911$, and 1912, the vast outpouring of the new West in wheat, other grains, and animal products all were made possible by the railroads, and they in turn by the land grants. Later generations were to question the wisdom of the policy but few could have foreseen the subsequent problems in advance.

GATES, supra note 54 , at 381 .

104. See John Hoyt Williams, a Great and Shining Road: The Epic Story of the TRANSCONTINENTAL RAILROAD (1988).

105. See Hanson, supra note 33; Wilner, supra note 5; Charles Montange, Conserving Rail Corridors, 10 TEMPLE EnVTL. L. \& TECH. J. 139 (1991).

106. See Byron K. ElliotT \& William F. Eluott, a Treatise on the law of Rallroads 1291 (1897); Philip Danielson, The Real Property Interest Created in a Railroad Upon Acquisition of its "Right of Way". 27 ROCKY MTN. L. REV. 73 (1954). 
limited or conditional easement, or a license. ${ }^{107}$ Some states, however, limited the types of property interests the railroads could acquire through adverse possession or condemnation. ${ }^{108}$ Throughout most of the 19th century, courts made fine distinctions among the various types of property rights the railroads could acquire. But by 1900 , anti-railroad animus caused many courts to hold that all ambiguities and presumptions were to be resolved in favor of the grantor landowners. ${ }^{109}$ The result was that many courts simply imposed a binary structure on railroad title disputes: either the railroad acquired fee simple absolute title, allowing it to do virtually anything it wanted with its land, even if it had discontinued services and abandoned certain parcels, or the railroad acquired merely an easement or a right-of-way ${ }^{110}$ over the original landowner's land, extinguishable under principles of abandonment.111 This binary structure elides important differences among the different property interests and their methods of acquisition.

\section{Property Interests in a Rail Corridor}

On a continuum of property interests, the largest interest a railroad could acquire is a fee simple absolute, and the smallest interest a railroad could acquire is a license. Just as any landowner may impose conditions and limit a grant of land, so, too, did many of the landowners who negotiated to sell to the railroads. Often landowners would condition grants on a time limit for construction of the line, ${ }^{112}$ on operation of rail services, ${ }^{113}$ on providing certain fencing, or on providing certain

107. See NiciHOLs', supra note $11,811.01$ [a] (discussing property rights a railroad may acquire).

108. See 1871-72 111. Laws $\S 17$ (limiting rights under condemnation).

109. See supra notes 94-97 and accompanying text.

110. The term "right-of-way" has two common meanings. To avoid confusion, we will limit use of the term as much as possible and instead substitute the two synonyms: "easement" or "corridor" where appropriate.

111. For a quick introduction to the case law on railroad deed interpretation, see J. Connelly, What Constitutes Abandonment of a Railroad Right of Way. 95 A.L.R.2d 468 (1964); A.E. Korpela, Deed to Railroad Company as Conveying Fee or Easement, 6 A.L.R.3d 973 (1966).

112. Typical language would be "grantor conveys and warrants the following described land ... but if the railroad is not constructed within two years the land reverts back to me."

113. A reverter clause would explain that if the railroad use were to cease, the land would revert to the grantor, or the clause might limit the use of the property to "railroad purposes." 
rail services. ${ }^{114}$ These various conditions have been interpreted either as precatory language that places no limit on the grant, as a condition that limits the grant to some type of defeasible fee with a future interest in the grantor, or as an easement for surface use, especially where mineral rights were explicitly reserved.

Although each railroad line used its own form deed, most railroad corridors held a wide variety of these types of interests, corresponding to the wishes and desires of individual landowners. In most cases, the railroad would use a fee simple absolute deed and simply add any conditions or limitations to the habendum clause to create a defeasible fee. While the term easement was commonly known, it was rarely used because the common law easement of the nineteenth century did not permit the easement holder to have exclusive rights in the land. Railroads required such exclusivity for the safety and function of the line. ${ }^{15}$ Use of the term easement did not generally appear in original railroad deeds until the turn of the century, and they were most frequently used when a successor railroad needed a wider corridor and sought to widen a pre-existing line by 50 or 100 feet.

The fact that a mid-nineteenth century deed would appear in the form of a defeasible fee or an easement, however, did not mean that courts would interpret the railroads' property interests according to strict rules of deed construction. Until the 1880 s, in most land disputes between the railroads and original grantors, the railroads won because either the land granted was found to be in fee simple absolute, or the railroads' exclusivity needs required a strong property interest. As public enthusiasm for the railroads waned, however, so did judicial deference. Not until the turn of the century did the case law invoke the presumption against the grantee railroad as the drafter of the deed or the presumption in favor of easements. As railroads began to fail, or as they provided fewer services than expected, courts began to interpret the original granting documents strictly and narrowly. If the railroad was still operating, it would be deemed to hold only the smallest property right possible consistent with its operational needs. ${ }^{16}$ If it had abandoned its

114. For example, the grantor could condition the grant on the construction of a depot within a particular distance or on the promise to stop the train at the grantor's farm for loading or unloading crops and supplies.

115. See Midland Valley R.R. v. Sutter, 28 F.2d 163 (10th Cir. 1928).

116. See Brinker v. Union Pac. D. \& G. Ry. Co., 55 P. 207 (Colo. App. Ct. 1898); James v. Indianapolis \& St. Louis R.R. Co., 91 Ill. 554 (1879). 
line, courts often found that the grant had conveyed a mere easement that was extinguished by abandonment. This turn-ofthe-century trend continues today.

The sixth possible property right, the license, is relatively rare as licenses are, by their nature, revocable by the fee owner. Railroads are reluctant to take only a license if they plan to invest heavily in affixing structures or improving the land. Any license, therefore, entails extensive and well-documented contractual negotiations to address in advance, and hopefully avoid, the possibility of revocation. ${ }^{117}$

\section{Methods of Acquisition}

When a railroad acquired its land from a private landowner by a private grant, it usually obtained a deed or a contract stating the type of interest it was acquiring. In some instances, however, the railroad may have been unable to obtain a deed because the landowner was either unable or unwilling to grant one. Some of these parcels were simply acquired by prescription and a note to that effect appears in all valuation charts filed with the Interstate Commerce Commission. Some railroads lost all their original granting documents through fires and floods, and they have had to reconstruct their landholdings from courthouse records. In other instances, the courthouse itself burned, leaving the only reliable records with the railroad. If the railroads were unable to locate granting documents in the 1920s and 1930s when they compiled their valuation charts, these parcels were denoted as acquired by adverse possession. If they acquired their parcels by condemnation or by state or federal land grant, that too was noted.

As a general rule, parcels acquired by private grant, either deed or contract, may take the form of any of the six property interests outlined above. Acquisition through any of the other three methods, however, may be limited because they are fundamentally conveyances by operation of law or state action. Some states have restricted the interests the railroads could acquire through adverse possession or condemnation to limited easements. ${ }^{118}$ Others find that parcels acquired through prescription are narrowly defined to the minimum land necessary for actual use, even when the allowable width identified in the charter or general right-of-way statute is

117. See Danielson, supra note 106 , at 73.

118. See supra notes $94-96$ and accompanying text. 
greater. ${ }^{119}$

For lands obtained by federal grants, the property interest in the corridor itself will be limited to an easement or a defeasible fee, though the land acquired for resale will be a fee simple absolute. The United States Supreme Court held that pre-1871 railroads did not receive the mineral rights underlying their corridors, but that they received a "limited fee" or defeasible fee interest. ${ }^{120}$ The 1875 Act has been interpreted to have conveyed to the railroads exclusive easements that included subsurface rights, though not mineral rights. ${ }^{21}$

State grants of land took one of two forms. First, they could be direct grants from state-owned lands of either fee simple title or easements in which the interest conveyed is determined by the granting documents or state statutes. Second, the grants could be federal government grants that passed first through state hands, as did the Illinois Central grants. Where the federal government gave the land to the states to turn over to the railroads, the interests will be interpreted under the rules governing federally granted rights-of-way. ${ }^{122}$ Lands granted directly by the states, however, will vary according to the railroad charter, municipal agreements, or state statute. Some states mimicked the 1852 federal right-of-way statute by providing state right-of-way grants as well.

Courts will allow the railroads to acquire any interest by private grant on the assumption that the parties may freely contract to buy or sell any interest in land they choose. But where land is acquired by the railroads through operation of law

119. See Meyer v. Pittsburgh, Cincinnati, Chicago \& St. Louis Ry. Co., 113 N.E. 443 (Ind. Ct. App. 1916).

120. See United States v. Union Pac. R.R. Co., 353 U.S. 112, $118-19$ (1957).

121. See Great N. Ry. Co. v. United States, 315 U.S. 262, 279 (1942). Although the federal courts had a rather difficult time explaining that post-1875 "rights-ofway" were easements while pre-1871 "rights-of-way" were limited fees, it is generally agreed that the difference is not particularly meaningful in terms of the railroad's exclusive use and control of the land; rather, it originally made a difference only in terms of mineral rights. The courts do seem clear, however, that the limits imposed on the pre-1871 grants are of duration only, while the limits imposed on the post1875 railroad easements are potentially of scope and duration. Compare Northern Pac. Ry. v. Townsend, 190 U.S. 267, 271 (1903) (holding the railroad's interest in pre1971 charter rights of way to be a "limited fee"), with Great N. Ry. Co. v. United States, 315 U.S. 262, 278 (1942) (holding that post-1875 right-of-way grants are of easements only). The Department of the Interior interprets the post-1875 easements to be, for all practical purposes, a new estate that falls somewhere between a common law easement and a defeasible fee. See DEP'T OF THE INTERIOR, PROPOSED INSTALlation OF MCI FIBER OPTIC COMMUNICATIONS LINE WITHIN SOUTHERN PACIFIC TRANSPORTATION CO.'S RAILROAD RIGHT-OF-WAY (1989). available at 1989 WL 434834.

122. See City of Maroa v. Illinois Cent. R.R., 592 N.E.2d 660 (Ill. App. Ct. 1992). 
or state action, they may be limited to only the minimum property interest necessary for their purposes. Determining the minimum interest needed, the railroad's purposes, and the grantor's intent entails rules of deed construction that vary dramatically from state to state.

\section{Construction of Railroad Title Documents}

Deed interpretation of nineteenth-century railroad documents is a complex process, implicating many considerations and policies, including the use behind the grant, the current state of railroad operations, and the legal implications for future heirs of future interests. While no configuration is consistent throughout all state courts, most railroad title disputes involve recurring concerns.

The fee simple absolute is the most complete property interest that can be held by private landowners. Most states had statutes in the mid-nineteenth century that outlined the language necessary or sufficient to create such an estate. Typically, the instrument would "convey and warrant" the "land" described in the text that followed, with no limitations on use or duration. Defeasible fee interests use the same granting language but include a limitation on use (for example, "for railroad purposes") or duration (for example, "so long as the railroad is built within five years") in the habendum clause. Easements are generally created by language that grants a right, rather than the land itself, such as a right-of-way or a right to construct and operate a railroad. A limited use easement is further limited by use (for example, "so long as used for railroad purposes"). Courts, however, dislike analyzing the subtleties attendant on these different estates and often will impose a binary structure on railroad title disputes: either the railroad acquired a fee simple absolute or a limited use easement. Everything in between drops out even when those middle interests more accurately reflect the intentions of the original parties. ${ }^{123}$ For example, one court simply explained that: "when the granting clause of a deed declares the purpose of the grant to be a right-of-way for a railroad the deed passes an easement only, and not a fee with a restricted use, even though the deed is in the usual form to convey a fee title. ${ }^{124}$

123. See, e.g., Daugherty v. Helena \& N.W. Ry., 252 S.W.2d 546 (Ark. 1952); Askew v. Spence, 79 S.E.2d 531 (Ga. 1954).

124. King County v. Squire Inv. Co., 801 P.2d 1022, 1024 (Wash. Ct. App. 1990) (quoting Swan v. O'Leary, 225 P.2d 199, 201 (Wash. 1950)). See generally Korpela, 
If a railroad acquired a perpetual or general easement, then the easement exists in perpetuity, regardless of whether or not the company operates a railroad on the land. ${ }^{125}$ These rare perpetual or general easements are found only where no language in the grant specifies the type of use the railroad may make of the land. ${ }^{126}$ The holder of such an easement can expressly abandon the easement, but a court will not imply abandonment when the easement holder changes or abandons its use. With a limited use easement, however, the railroad's property interest will terminate upon cessation or change in use. ${ }^{127}$

Additionally, most courts construe grants in the context of the actual use to which the land has been put. Where the railroads constructed buildings such as depots and warehouses, most courts presume that ambiguous deeds conveyed fee simple absolute to the railroads, inferring that the parties intended a fee simple conveyance if the grantor permitted the railroad to build permanent buildings. ${ }^{128}$ But where an identically worded deed conveys land for the rail corridor, ${ }^{129}$ courts will often construe the grant to convey only an easement on the so-called public policy that:

Transaction costs are minimized by undivided ownership of a parcel of land, and such ownership is facilitated by the automatic reuniting of divided land once the reason for the division has ceased. If the railroad holds title in fee simple to a multitude of skinny strips of land now usable only by the owner of the surrounding or adjacent land, then before the

supra note 111 (discussing cases finding easements).

125. See, e.g., Graham v. St. Louis Iron Mountain \& S. Ry. Co., 65 S.W. 1048 (Ark. 1901); Randolph v. Martin, 100 So. 2d 198 (Fla. Dist. Ct. App. 1958); Champaign Nat'l Bank v. Illinois Power Co., 465 N.E.2d 1016 (Ill. App. Ct. 1984); Housing Eng'g Co. v. David M. Andrews Co., 40 A.2d 368 (Md. 1945); Norfolk \& W. Ry. Co. v. Bremco Mills, Inc., 288 N.E.2d 868 (Ohio Ct. C.P. 1971); Cruzan v. Missouri-Kan.-Tex. R.R. Co., 303 P.2d 313 (Okla. 1956).

126. See JON W. BRUCE \& JAMES M. ElY, JR., THE LAW OF EASEMENTS AND LICENSES IN LAND \$ 9.01 (1988); Chevy Chase Land Co. v. United States, 733 A.2d 1055, 1064 (Md. Ct. Spec. App. 1999).

127. See BRUCE \& ELY, supra note 126, \$ 9.02.

128. Land to be used for depot or station purposes will almost always be held in fee by the railroads. See, e.g., Askew v. Vicksburg. Shreveport \& Poe Ry. Co., 132 So. 510 (La. 1931); Hale v. Davis, 195 S.E. 523, 524 (Va. 1938).

129. In 1871, Congress amended its land grant statute to limit such grants to easements only for corridors, though not for buildings and other fixtures. General Railroad Right of Way Act of Mar. 3, 1875, ch. 152, 18 Stat. 482 (codified at 43 U.S.C. § 934 (1994)). Similarly, the Indiana general assembly amended its eminent domain statute in 1905 to limit railroads to taking only easements in corridor land, though their rights to take full fee title for other lands remained unimpaired. See IND. CODE ANN. § 32-11-3-1 (Mitchie 1999). 
strips can be put to their best use there must be expensive and time-consuming negotiation between the railroad and its neighbor - that or the gradual extinction of the railroad's interest through the operation of adverse possession. It is cleaner if the railroad's interest simply terminates upon abandonment of railroad service. A further consideration is that railroads have eminent domain powers, and they should not be encouraged to use those powers to take more than they need of another person's property- more, that is, than a right of way. . . 130

Courts construe a grant to avoid finding defeasible fees for similar policy reasons. With a defeasible fee, the possibility of reversion remains in the original grantor and usually passes to his or her heirs rather than to successors in interest of the adjoining land. ${ }^{131}$ Locating lost heirs over time becomes difficult, and so judges often construe to avoid such fees:

The evils resulting from the retention in remote lowners of the titles in the strips of land over which railroads run,] which for many years are valueless because of the public easement...., and which then become valuable by reason of an abandonment of the public use, have led courts to strange constructions to include the fee of such ... strips in [the] deeds of the abutting lots. And modern decisions are even more radical in this regard than the older cases. ${ }^{132}$

In addition, even when the deed evinces clear intent to convey fee title by using the requisite statutory fee language, some courts will rule against the railroads out of what can only be described as general anti-railroad animus. ${ }^{133}$

Some states have addressed this problem by statute,

130. Consolidated Rail Corp. v. Lewellen. 666 N.E.2d 958, 962 (Ind. Ct. App. 1996), affd, 682 N.E.2d 779 (Ind. 1997).

131. See Chevy Chase Land Co. v. United States, 733 A.2d 1055, 1064 (Md. 1999); Stuart v. Fox, 152 A. 413 (Me. 1930); Garry v. Atchison, Topeka \& Santa Fe Ry. Co., 378 P.2d 609, 611 (N.M. 1963); McDonalds Corp. v. Dwyer, 432 S.E.2d 165 (N.C. Ct. App. 1993); King County v. Squire Inv. Co., 801 P.2d 1022 (Wash. Ct. App. 1990); Wood v. Board of County Comm'rs, 759 P.2d 1250 (Wyo. 1988).

132. Paine v. Consumers' Forwarding \& Storage Co., 71 F. 626, 632 (6th Cir. 1895); see also, e.g., Jones v, Lane, 669 So. 2d 161 (Ala. 1995); Rogers v. Pitchford, 184 S.E. 623 (Ga. 1936); Tallman v. Eastern Illinois \& Peoria R.R. Co., 41 N.E.2d 537 (Ill. 1942); Ross, Inc. v. Legler, 199 N.E.2d 346 (Ind. 1964); Sherman Petroleum Exploration. 132 S.W.2d 768 (Ky. 1939). Despite the desire to limit a railroad's interests to an easement, the public's interest in these quasi-public parcels is undermined. See infra Part II.C (discussing unified theory of multiple-use railroad easements).

133. See Consolidated Rail Corp. v. Lewellen, 666 N.E.2d 958 (Ind. Ct. App. 1996), affd, 682 N.E.2d 779, 782 (Ind. 1997) (citing "public policy" reasons for ruling against railroad); see also DANAYA C. WRIGHT, PRIVATE RIGHTS AND PUBLIC WAYS, 74652 (1997). 
transferring title in the reversionary future interest to the adjoining landowner. ${ }^{134}$ However, at least one state's law has been held to work an unconstitutional taking of the heir's property rights. ${ }^{135}$ The better approach is to interpret the deed to convey fee simple absolute to the railroad, or a defeasible fee that converts to a fee simple absolute through destruction of the reversion by either the marketable title act or the performance of the condition for a sufficient period (thus satisfying and destroying the condition).

Judges who believe they are making things simpler by consistently finding that railroad corridor instruments always convey easements are mistaken. Numerous cases detailing the nature of the easement granted to railroads under federal land grants have held that the "easements granted thereby were not intended to be construed within the traditional definition of an easement."136 The nature of railroad use demands that the servient fee owner has something less than a fee subject to an easement, and the easement owner has something closely

134. Marketable Title Acts have been enacted recently to extinguish contingent remainders and possibilities of reversion in an effort to limit dead hand control. See CUNNINGHAM ET AL., supra note 77, at 855-58 (2nd ed. 1993); see also, e.g., McKinley v. Waterloo R.R. Co., 368 N.W.2d 131 (lowa 1985) (extinguishing reversionary interests as of date of marketable title act, thus converting the railroad's defeasible fee interest into fee simple absolute).

When the original grantor conveyed a strip of land for the railroad, often bisecting his land, the remaining pieces would generally be sold later as separate parcels, identifying one boundary by the edge of the railroad corridor. These subsequent conveyances would generally not include a description of the land underlying the railroad corridor. The presumption arises, therefore, that the grantor retained the reversionary interest in the railroad corridor, which passed to his heirs and was not included in later conveyances of the retained land. See NicHOLs', supra note 11, \& 21.05[3][b] (stating that in "order to be certain of the accurate interpretation of the originating grant, one must check to see if it was modified or extended. Additionally, one must also carefully examine the language of the deeds conveying the adjacent right of way to be certain the railroad right-of-way has not been excluded. An express exception within a deed, by conveying property 'less' than the railway right-of-way, is a clear and plain expression of the intent to exclude the right-of-way from the deed transfer." (citations omitted)); see also, e.g., King County v. Squire Inv., 801 P.2d 1022 (Wash. Ct. App. 1990); McDonalds Corp. v. Dwyer, 432 S.E.2d 165, 166 (N.C. Ct. App. 1993); Stuart v. Fox, 152 A. 413 (Me. 1930); Paul v. Connorsville \& Newcastle Junction R.R. Co., 51 Ind. 527 (Ind. 1875).

A handful of state statutes, however, will give the adjoining landowner title to the centerline of the rail corridor upon abandonment. See, e.g., IOWA CODE ANN. § 327G.77 (WEST 1997); IND. CODE ANN. \$ 32-5-12-10 (Mitchie 1999); N.C. GEN. STAT. \$ $1-44.2$ (1999).

135. See McDonalds Corp. v. Dwyer, 432 S.E.2d 165, 170-71 (N.C. Ct. App. 1993); Cary Ent. v. CSX Transp. Inc., No. 95-03311-CH (Mich. 29th Cir. Ct. Apr. 19, 1996).

136. Puett v. Western Pac. R.R. Co., 752 P.2d 213, 216 (Nev. 1988) (citing Idaho v. Oregon Short Line R.R. Co., 617 F. Supp. 207 (D. Idaho 1985), for a lengthy history of the nature of railroad rights-of-way). 
approaching fee title. Fitting the interests into common-law categories is counter productive.

While it is understandable that private corporations, using eminent domain powers, should not be allowed to abuse their rights at the expense of private landowners, nearly a century and a half has elapsed since many of these interests were acquired. Rural farms, bisected by a corridor, are now residential subdivisions with an undeveloped greenbelt providing recreational and utility services. When the trains did not discontinue operations until the past decade or so, the land rights of the railroads and the adjacent landowners had coexisted, in most cases, for over 100 years. Many landowners may have come and gone in that time and successive deeds may have dropped references to the railroad corridor. Quieting the interest in the long-term user makes sense on many different levels.

Property law doctrines, first and foremost, try to prevent upsetting settled expectations. Finding fee title in the railroad would further the public policy of quieting title that underlies our doctrines of adverse possession, the rule against forfeitures, marketable title acts, the rule against perpetuities, and rules against transfers of future interests. This is especially true when there is little, if any, expectation on the part of adjoining landowners to receive the windfall of a rail corridor. ${ }^{137}$

Moreover, a strong public interest exists in preserving these corridors for trails and utilities. Perhaps the strongest policy motive in favor of the railroads is that evidenced by federal regulations concerning railroad services and the abandonment of rail corridors. Many of these corridors were assembled with public funding, public land, and eminent domain powers. They are, in a fundamental way, public assets. To the extent that deed construction can further protect the public's interest, especially when the cost to landowners is minimal, the courts have an obligation to realize that the public is a party to these cases as well. When landowners do not have title to the corridor land, heirs of the grantor are long gone, and the corridor can continue to provide vital public utility, recreational, environmental, and transportation services, there is no reason to continue the century-old anti-railroad animus that prevailed in the days of

137. A similar argument was upheld at one stage of the lengthy Preseault litigation, and it has been held that a landowner lacking a deed has no right to challenge a railroad's title. See King County v. Squire Inv. Co., 801 P.2d 1022, 1027 (Wash. Ct. App. 1990) (holding that adjacent landowner had no interest in railroad's right-of-way). 
frontier expansion. Precedents lose their legitimacy when times change.

\section{E. What the Railroads Can Do with What They Own}

Few title disputes occur regarding land actually and currently being used by a company for its railroad. ${ }^{138}$ Modern cases overwhelmingly involve ownership of the land after the railroad has abandoned services and removed its tracks and ties. ${ }^{139}$ When a railroad is found to hold a fee of some sort, the railroad will usually retain its property after discontinuation of rail services. Easements, however, are more likely to be deemed abandoned upon such discontinuation. But what rights a railroad has to authorize additional uses on the corridor, either pre- or post-abandonment, is a matter of much contention.

If the railroad holds its interest in fee simple absolute, its rights are unaffected by abandonment. ${ }^{10}$ It can alienate or encumber its land without limitation and can make whatever use of its land that is consistent with inherent limitations on title and background principles of nuisance law. If the railroad ceases to operate on the land or even removes its tracks and ties, it still owns the land and may continue to use it for any purpose or may choose to sell it without considering neighboring landowners. ${ }^{141}$

A railroad that acquired a defeasible fee, either a fee simple subject to a condition subsequent or a fee simple determinable, may use the land subject to the conditions of the deed- usually

138. Many cases do address whether the underlying fee owner may reoccupy part of a railroad easement that is currently left unused so long as she does not interfere with the part being used. See, e.g., Mellon v. Southern Pac. Transp. Co., 750 F. Supp. 226 (W.D. Tex. 1990); Buhl v. United States Sprint Comm. Co., 840 S.W.2d 904 (Tenn. 1992).

139. See, e.g., Consolidated Rail Corp. v. Lewellen, 682 N.E.2d 779, 782 (Ind. 1997); King County v. Squire Inv. Co., 801 P.2d 1022 (Wash. Ct. App. 1990); Glosemeyer v. Missouri-Kansas-Texas R.R., 879 F.2d 316 (8th Cir. 1989).

140. An adjacent landowner may acquire title through adverse possession if she meets the requisite statutory requirements. See, e.g., Erie R.R. Co. v. Kaplowitz, 137 N.Y.S.2d 261 (N.Y. Sup. Ct. 1954); Simacek v. York County Rural Pub. Power Dist., 370 N.W.2d 709,713 (Neb. 1985). Of course, if the use is permissive by the railroad, no prescriptive rights will accrue to the landowner. See, e.g., Chicago \& S.E. Ry. Co. v. Wood, 66 N.E. 923 (Ind. Ct. App. 1903). And of course, if the railroad only holds an easement, the fee owner's nonpermissive use of the easement cannot be adverse because the fee owner already owns the fee. See, e.g., Southern Ry. Co. v, Vann, 216 S.W.2d 727 (Tenn. 1919).

141. See Eldridge v. City of Greenwood, 503 S.E.2d 191, 209 (S.C. Ct. App. 1998) (recognizing free availability right that comes with fee simple absolute in land); Tazian v. Cline, 686 N.E.2d 95 (Ind. 1997): O'Dess v. Grand Trunk Western RR. Co., 555 N.W.2d 261 (Mich. Ct. App. 1996). 
that the railroad use the land only to operate a railroad. As long as the railroad fulfills the deed conditions, it may also authorize concurrent use by utilities. ${ }^{142}$ The railroad's present interest may terminate when it stops using the land to provide rail services, and the owner of the reversionary rights of the original grantor may be able to re-enter and reclaim title to the land if the future interest has survived the state's marketable title act. ${ }^{143}$ In addition, common law presumptions against forfeitures may also defeat the grantor's future interest, as may rules preventing the alienation of certain future interests. ${ }^{144}$ But if the future interest survives, it will determine upon cessation of railroad use. While non-railroad uses were permissible during the period of the railroad's ownership, such uses may become trespasses once the reversionary interest is triggered.

If the railroad held only an easement, then its use of the land may be limited in type and duration; the railroad may also lack the power to transfer its rights to other owners. ${ }^{145}$ Discontinuation of rail service may amount to abandonment of the easement, allowing the owner of the underlying fee to use and occupy the previously burdened land without restriction. ${ }^{146}$ Non-use of a perpetual easement, however, will not cause abandonment, though third party utility or trail use may have exceeded the scope of the easement. Discontinuing rail service, therefore, is much more significant in the context of easements than it is in the context of fees. ${ }^{147}$

Even when courts have reduced the quiet title issue to the binary choice between fee simple absolute and easement, they have consistently recognized that the easement is bigger, more

142. See Taylor Inv. Co., v. Kansas City Power \& Light Co., 322 P.2d 817 (Kan. 1958).

143. See Brookbank v. Benedum-Trees Oil Co., 131 A.2d 103, 112 (Pa. 1957).

144. Farrell v. Hodges Stock Yards, Inc., 343 So. 2d 1364, 1371 (La. 1977); Wood v. Board of County Comm'rs, 759 P.2d 1250 (Wyo. 1988); Paul v. Connorsville \& Newcastle Junction R.R. Co., 51 Ind. 527 (Ind. 1875). In some states. possibilities of reversion are nontransferable on the grounds that contingent future interests are bare expectancies. See Denver \& Santa Fe Ry. Co. v. School Dist. No. 22, 23 P. 978 , 980 [1890).

145. The typical easement is for railroad purposes, which limits the easement holder to operating a railroad on the land. However, whether the courts will interpret that limitation broadly or narrowly is a matter of state law. See infra Part III.D.2. (discussing Incidental Use Doctrine); see also BRUCE \& ELY, supra note 126, § 9.02.

146. See infra Part V (discussing abandonment).

147. As discussed later, however, abandonment is an incredibly complex issue, as abandonment of the easement is often confused with discontinuance of rail services and the removal of the line from federal Surface Transportation Board (STB) jurisdiction. See id.; see also Marc A. Sennewald. The Nexus of Federal and State Law in Railroad Abandonments, 51 VAND. L. REV. 1399 (1998). 
extensive, and exclusive as against the fee owner than most private easements and public utility easements. ${ }^{148} \mathrm{~A}$ railroad easement is even more exclusive against the fee owner than a highway easement. The owner of the fee underlying the highway can still drive on the highway as a member of the public, but the only way the owner of the fee underlying the railroad may enter her burdened land is to buy a ticket and ride the train through it. In fact, courts have had great difficulty defining the railroad easement because it so closely resembles the exclusive dominion and control of fee simple ownership. This difficulty is especially pronounced when the railroad has acquired its interest under eminent domain or by private grant; in these cases, the railroad usually will have paid the full fair market value for fee title. ${ }^{149}$

Therein lies the heart of this study. When the railroad holds only an easement, does the exclusive character of the easement and its extensive scope confer upon the railroad the power to grant licenses or subeasements to utility companies or allow recreational trail use? Does that power depend on whether the railroad acquired its easement through purchase, through eminent domain, or from a federal grant? What happens to utility rights when the railroad abandons? What happens if a railroad discontinues rail services and has the line removed from federal jurisdiction, but continues to claim ownership of the easement and maintains or pays taxes on it? ${ }^{150}$ The rights of utilities in rail corridors are tremendously unstable in the absence of any consistent rulings on these issues. ${ }^{151}$

Because of the importance of rail corridors for utility services and the growing demand for rails-to-trails conversions, the question of the railroad's power to grant these utility licenses or

148. See infra Part III.B (discussing exclusivity).

149. Although modern landowners often claim that the railroad paid less than fair market value for land when they paid only $\$ 100$ or $\$ 200$ for a 100 -foot-wide strip of land running over 20 or 40 acres, this often amounted to two or three times the fair market value of unimproved land or farmland. For instance, in Indiana, the average value of an acre of farmland in 1870 was $\$ 28$, in 1880 it was $\$ 31$, in 1890 it was $\$ 37$, in 1900 it was \$39. and in 1910 it was \$75. See INDIANA CROP \& LJVESTOCK REPORTING SERVICE, HISTORIC CROP SUMMARY, 1866-1969, at 142 (1974) (citing Economic Research Serv., U.S. Dep't of Agriculture, Farm Real Estate Developments).

150. See generally AMON, supra note 7. As the lead attorney for these class action cases explained, he and the rest of his co-counsel are attempting to set up a land cooperative, complete with a federal patent, that would allow the cooperative to license utility uses in these corridors. That would seem to necessitate some sort of control over an extensive portion of these corridors, lands that he claims should be returned to the adjacent landowners.

151. Witness the twenty-five class action suits filed against the railroads and utilities. See AMON, supra note 7, at A1. 
subeasements takes on new significance. ${ }^{152}$ The recent spate of class action cases, therefore, implicates a wide variety of state and federal statutes, common law, and public policy regarding railroads, railbanking, trail use, and utility services, and raises profound questions about the rule against creation of new estates. It is simply not enough to say that the utility license stands or falls on the strength of the railroad's property rights. Until we have a better sense of the exact scope and nature of the railroad's property rights and the conditions under which those rights might be extinguished, we will be unable to ascertain what rights the utilities acquired and whether or not they must also negotiate with individual landowners who may or may not have coterminous rights in the rail corridor. In the next Part, we explore the scope, duration, and use of the railroad easement.

III

THE LIMITED EASEMENT FOR RAILROAD PURPOSES

The cardinal rule in property law is that one cannot sell what one does not own. In property law parlance, we refer to property rights as a bundle of sticks, where fee simple title is envisioned as ownership of the entire bundle. The owner of the bundle can sell or give various sticks to different people, or can divide ownership over time by designating who will own the various sticks in the bundle at various times. The same is true if one only owns a few sticks from the bundle, as with an easement. If a railroad owns only an easement in a parcel of land, it cannot sell something greater than that easement to someone else without unjustly converting the property rights of the fee owner. But the railroad can sell all of its sticks to someone else, as when it conveys to a successor railroad all of its property along a given line, or it can sell one or two sticks and retain the remaining sticks. ${ }^{153}$

But to say that a railroad easement owner can sell part of its easement while retaining the rest does not tell us whether it can sell the right to string wires or lay pipelines to a utility. We must first determine whether the right to string wires or pipes was a stick in the railroad's small bundle in the first place. If not, that right remains with the underlying fee owner. To answer that question, we must analyze the scope of the railroad easement.

152. See generally Wilner, supra note 5 (discussing importance of rail corridors for utilities).

153. See NICHOLS', supra note $11, \S 11.01[2][c]$; CUNNINGHAM ET AL., supra note 77, $\$ 8.10$. 
This Part attempts to deduce a coherent theory about the nature, parameters, and powers of the limited railroad easement. ${ }^{154}$ On the one hand, the railroad easement is exclusive in a way that most easements are not. The railroads have exclusive rights to possession of their corridors and may exclude the fee owner from access to her land. On the other hand, railroads do not have unlimited development rights because the railroad easement is limited to railroad use. The owner may not, for example, operate a petunia farm on the corridor. The key task is to locate the boundary between the railroad's exclusive control and the restrictions placed on the corridor's use. That boundary determines the answer to numerous questions:

- May the railroad lease corridor land to a private company that operates warehouses, loading docks, or a restaurant for train passengers?

- May it authorize construction of telegraph lines that will be used to send communication signals to stations and switches to regulate train traffic? If so, may it allow the telegraph company to also send private, non-railroadrelated communications for profit?

- May it authorize water lines or drainage culverts to minimize run-off from the artificial roadbed embankments?

- May it extract gravel from the easement to build its bed?

- May it extract coal, oil, or titanium from its easement to sell for profit to fund the railroad? How far below the surface may it dig and how high in the air may the trains, water towers, communications lines, bridges, or other structures reach?

- May it operate one hundred trains an hour without owing damages to the servient landowner?

- May a logging railroad take up its tracks and ties and sell the easement for operation as a logging road?

- What, if anything, can we learn from the publicly-owned street and highway cases where utilities are frequently located along street rights-of-way?

- What expectations and rights do adjacent landowners have in railroad corridors if their deed does not include the rail corridor?

154. The limited railroad easement must be distinguished from the general easement. If there is no use restriction, then divisibility is permitted so long as the burden on the easement is not unreasonably increased. It is only when the scope is limited to certain uses that deviation from that use is a violation of the easement and may work an extinction. See Hegi, supra note 44, at 134 . 
- What effect, if any, do the different types of easement, whether by private grant or by federal grant, have on the ability of the railroads to authorize third-party use of their corridors?

Certainly we cannot exhaustively answer all of these questions in detail for every state. Most states have not addressed more than one or two of these questions. What follows, therefore, is a general summary of the state of the law with regard to many of these issues with the purpose of drawing forth a coherent set of rules that will allow judges and lawyers in future cases to better delineate the parameters of the railroad's, the utility company's, the landowner's, and the public's rights in these valuable corridors. The fiber-optic and rails-to-trails cases are merely the catalyst for a much broader discussion of how the legal system should regulate the competing needs of private property owners, developing areas requiring necessary utilities, and those who wish to use these corridors for high-speed trains or as trails and greenways into the next century.

\section{A. A Right-of-Way by Any Other Name...}

The principal difficulty in interpreting what property rights the railroads have acquired in their corridors comes from the dual meaning of the term "right-of-way." The term means, first, a right of passage or a right to come onto someone else's land, and, second, a railroad or street corridor. ${ }^{155}$

When the term "right-of-way" is used in the first sense, it is a legal term of art referring to a right to pass over someone else's land. This legal definition most closely resembles an easement. although technically an easement is broader than a right-of-way because it permits the owner both to pass across the land and to use the land in certain ways, as in constructing and operating trains. A true right-of-way derives from old English traditions allowing passers-by to traverse one's land to reach public roads. ${ }^{156}$ The passer-by is not entitled, by virtue of the right-ofway, to plant petunias or run livestock if the right is simply a

155. See BLACKS LAW DICTIONARY 1489 (4th ed. 1968) (explaining that the term "right-of-way" is sometimes "used to describe a right belonging to a party to pass over land of another, but it is also used to describe that strip of land upon which railroad companies construct their road bed, and, when so used, the term refers to the land itself, not the right of passage over it.").

156. See William Holdsworth, A History of ENGlish Law 301 (1938) (explaining the difference between a footway, a packe, and prime way (a footway plus a way for animals), and a via or aditus (a footway plus a horseway plus a cartway)). 
right of passage. ${ }^{157}$

The second meaning of right-of-way refers to the actual physical stretch of land on which the railroad has constructed its roadbed. In the nineteenth century, this second meaning was the one most often used. Indeed, the common deed language of the time usually conveyed and warranted "the following real estate: a right of way."

The U.S. Supreme Court recognized the dual nature of the term right-of-way in the context of railroad uses in Joy $v$. City of St. Louis. ${ }^{158}$ Judges, scholars, and commentators have since cited the term's dual meaning as the leading cause of ambiguity and litigation in railroad property cases. ${ }^{159}$ Unfortunately, because the federal railroad land grants use the term "right-of-way," as do most state statutes and a large percentage of private deeds, the so-called ambiguity is unlikely to disappear any time soon. ${ }^{160}$

Courts in the past few decades have not ameliorated the problem. Rather than engage the canons of construction, the recent trend has been to interpret any mention of the term rightof-way anywhere in the deed to imply that an easement was intended, even when the term clearly refers to the physical corridor and the deed uses statutory fee simple language. ${ }^{161}$ For instance, one court explained that "[w]here, by instrument or deed, land is purportedly conveyed to a railroad company for the laying of a rail line, the presence of language referring. in some manner to a 'right of way' operates to convey a mere easement notwithstanding additional language evidencing the conveyance of a fee." 162

But a conveyance of a fee simple is consistent with the term right-of-way in the granting clause when the term is used in its second meaning, "physical corridor." Courts fail to recognize the duality of the term "right-of-way" and therefore often misinterpret clear language conveying fee simple title to the

157. The passerby might even be prevented from stopping, resting, or picnicking along the way.

158. 138 U.S. 1,44 (1890).

159. See generally Consolidated Rail Corp. v. Lewellen, 682 N.E.2d 779 (Ind. 1997); Danielson, supra note 106, at 74; Korpela, supra note 111, $\$ 5$ (discussing relevant cases).

160. See Wright, PrVATE Rights, supra note 133, at 741; Danaya C. Wright, Trains, Trails and Property Law: Indiana Law and the Rails-to-Trails Controversy, 31 IND. L. REV. 754 (1998).

161. See, e.g., Consolidated Rail Corp. v. Lewellen, 666 N.E.2d 958, 962 (Ind. Ct. App. 1996) (holding that public policy reasons beyond the deed language may derogate from the grant), affd, 682 N.E.2d 779 (Ind. 1997).

162. Illinois Cent. R.R. v. Roberts, 928 S.W.2d 822, 825 (Ky. Ct. App. 1996). 
land. ${ }^{163}$ The federal courts themselves contributed to this confusion when they held that the pre-1871 land grants conveyed defeasible fees and the 1875-Act grants conveyed merely easements, even though the term "right-of-way" was the term used in both acts to describe the property right conveyed to the railroad. ${ }^{164}$ The courts' distinction was based not so much on the dual meaning of the term right-of-way but on changing definitions of legal easements to more appropriately include both characteristics of a railroad right-of-way. In fact, the term easement was rarely used in the nineteenth century when referring to railroad rights-of-way because a common-law easement generally did not convey exclusive rights to the land.

The second meaning of the term right-of-way most often arises in the habendum or descriptive clauses of a deed when references are made to the entire corridor or roadbed, as when the grantor reserves a grade crossing across the corridor or the railroad agrees to fence the corridor. ${ }^{165}$ This sense of the term is also common in fee simple deeds that use the existing corridor as a spatial reference (for example, "convey and warrant a strip of land, fifty feet on each side of the XYZ right-of-way") or use it to describe the actual land conveyed in the deed (as in "convey and warrant the following real estate: the right-of-way fifty feet wide"). ${ }^{166}$ In the latter use, especially, the term cannot mean "right-of-way" as "right of passage"; when taken together with the fee simple terms of the deed, the term must have been used in its second sense, meaning the land or rail corridor itself.

Because many nineteenth-century instruments only used the term right-of-way, and did not use either the term fee simple or easement, courts must continually attempt to deduce intent

163. In Lewellen, 682 N.E.2d at 780-82, the deed "[c]onvey[s] and [w]arrant[s] to the [Railroad] the Land, Right of way, and Right of Drainage," and the Indtana Supreme Court interpreted the deed to convey only an easement when what was clearly intended was fee simple in the corridor land, a right of access across the landowner's remaining land to reach the corridor for construction and maintenance, and a right to be free of liability for drainage onto the remaining land. The mere presence of the term right-of-way, which the court noted was a smaller interest than fee simple in the land, became the all-consuming issue.

164. Compare Northern Pac. Ry v. Townsend, 190 U.S. 267, 271 (1903) (holding right-of-way means a limited or defeasible fee), with United States v. Union Pac. R.R. Co., 353 U.S. 112, 119-20 (1957) (holding right-of-way to be an easement).

165. See Faus v. City of Los Angeles, 431 P.2d 849, 854 (Cal. 1967) (reference to fencing the right-of-way); Bouche v. Wagner, 293 P.2d 203, 207-09 (Or. 1956) (reference to a grade crossing over the right-of-way).

166. See, e.g., Johnson v. Valdosta, Moultive \& W. R.R. Co., 150 S.E. 845, 846-47 (Ga. 1929) (conveying a "strip of land sixty feet wide for a railroad right of way"); Cruzan v. Missouri-Kansas-Texas R.R. Co., 303 P.2d 313, 314 (Okla. 1956) (conveying land identified by reference to "the outer lines of the right-of-way"). 
from a highly ambiguous term. ${ }^{167}$ The most general rule one can derive from existing case law is that, if the term right-of-way appears in the granting clause, even if it merely refers to the physical corridor, the deed will most likely be construed to convey an easement. ${ }^{168}$ If the term appears in the habendum or descriptive clauses, the courts disagree; some find that an easement was intended, others that a fee simple was intended. Only absence of the term altogether, with clear fee simple or easement language, leads to a straightforward interpretation of the deed, though even this rule was not followed in some cases. ${ }^{169}$

Though the modern trend seems to be to interpret right-ofway simply to mean an easement, courts have agreed that the railroad easement is a unique and difficult-to-define property right that does not clearly fit into the easement or fee categories. ${ }^{170}$ As the Supreme Court has noted: "A railroad rightof-way is a very substantial thing. It is more than a mere right of passage. It is more than an easement."171 But it is not a fee. It has been called a "limited fee," ${ }^{172}$ a "perpetual easement," 173 a "right-of-way easement," ${ }^{74}$ and an "exclusive easement," 175 but

167. For instance, in Tompkins v. Atlantic Coast Line R.R. Co., 79 S.E.2d 41,45 (Ga. Ct. App. 1953), the term "fee simple" appeared in the granting clause but the court construed the deed to convey only an easement, holding that the "words in fee simple' are descriptive of the extent of duration of the enjoyment of easement conveyed," while in City of Manhattan Beach v. Superior Court. 914 P.2d 160 (Cal. 1996), the court held that the railroad had received a fee simple because the term "easement" was available to more accurately reflect the intent of the parties if they had meant to limit the conveyance to just a right of use. In our own research, we found that over fifty percent of deeds along a short line in Indiana were fee simple absolute deeds that did not even use the term right-of-way. There were also clear easement deeds that did not use the term either.

168. Although we believe this to be sloppy adjudication, it comports with the presumption that ambiguities in deeds are to be decided against the drafter, which in most cases was the railroad.

169. See, e.g., Tompkins v. Atlantic Coast Line R.R. Co., 79 S.E.2d 41 (Ga. Ct. App. 1953); Ex rel State Highway Comm'n v. Union Electric Co., 148 S.W.2d 503 (Mo. 1941) (interpreting the grant to be an easement despite the fact that the term "fee simple" appeared and there was no use of the term right-of-way).

170. See infra Part III.B (discussing exclusivity).

171. Western Union Tel. Co. v. Pennsylvania R.R. Co., 195 U.S. 540, 570 (1904).

172. Northern Pac. Ry. v. Townsend, 190 U.S. 267, 271 (1903).

173. Pratt v. Griese, 409 P.2d 777, 779 (Kan. 1966); Randolph v. Martin, 100 So. 2d 198, 198 (Fla. Dist. Ct. App. 1958).

174. AG Farms, Inc. v. American Premier Underwriters. Inc., 695 N.E.2d 882, 885 (IIl. App. Ct. 1998); see also Chevy Chase Land Co. v. United States, 733 A.2d 1055, 1063 (Md. 1999).

175. Forwood v. Delmarva Power \& Light Co., 1998 WL 136572, at *4 (Del. Ch. 1998); see also City of Maroa v. Illinois Cent. R.R., 592 N.E.2d 660, 664 (Ill. App. Ct. 1992). 
no court has clearly indicated the differences, if any, between these. Initially the courts seemed more likely to interpret ambiguous deeds for "railroad right-of-way" to be some form of defeasible fee. But by the early twentieth century, both federal and state courts had turned toward labeling the interest as an exclusive easement rather than a defeasible fee.

In 1893, with reference to federally granted rights-of-way, the Supreme Court characterized one railroad's right-of-way interest as "more than an ordinary easement" and likened it to a fee insofar as it had the "attributes of the fee, perpetuity and exclusive use and possession; also the remedies of the fee, and, like it corporeal, not incorporeal property." ${ }^{176}$ In 1898, the Court held the railroad's interest in a pre-1871 land grant to be a fee rather than a mere right of passage. ${ }^{177}$ But the Court acknowledged that although the interest looked like a fee, the appellant could justifiably disagree with that label. In 1903 the Court developed yet another term, "a limited fee,"178 because the grant was limited insofar as "the road shall be . . . used [only] for the purposes designed." 179 The right to alienate upon discontinuation of rail services was retained by the government. But payment of substantial consideration justified interpreting the grant to convey a fee interest rather than an easement. Hence, at least in pre-1871 grants, the courts interpreted the railroad's interest to be a defeasible fee with a condition of reverter if railroad use ceased.

In 1904 the same language and analysis was applied to a railroad interest under a state grant. ${ }^{180}$ The Court cited the "more than an easement" and "attributes of the fee" language from New Mexico $v$. United States Trust to find that a railroad's right-of-way was protected from condemnation by a telegraph company. ${ }^{181}$ In 1942, however, the Court found that grants under the 1875 Act constituted easements and not fees, though it recognized that the easement was not limited the way common-law private easements are, but, as later cases affirmed, carried with it the "right to exclusive use and occupancy of the land." 182 As the Tenth Circuit hypothesized, the

concept of 'limited fee' was no doubt applied in Townsend

176. New Mexico v. United States Trust Co., 172 U.S. 171, 183 (1898).

177. See id. at 182.

178. Northern Pac. Ry. Co. v. Townsend, 190 U.S. 267, 271 (1903).

179. Id.

180. See Western Union Tel. Co. v. Pennsylvania R.R. Co., 195 U.S. 540 (1904).

181. Id. at 570 .

182. State v. Oregon Short Line R.R. Co., 617 F. Supp. 207, 212 (D. Idaho 1985). 
because under the common law an easement was an incorporeal hereditament which did not give an exclusive right of possession. With the expansion of the meaning of 'easement' to include, so far as the railroads are concerned, a right in perpetuity to exclusive use and possession the need for the 'limited fee' label disappeared. ${ }^{183}$

In other words, as courts expanded their common-law easement doctrines to allow for exclusivity, railroad rights-of-way came to be labeled easements rather than defeasible or limited fees. This change has had a profound impact on railroad litigation in this century. ${ }^{184}$

State courts have had an equally hard time labeling the railroad's interest, especially in light of the fact that most railroad deeds did not use either of the terms "fee simple" or "easement" but often mimicked the supreme Court's characterization with regard to the type of interest being conveyed. In 1928, the Eighth Circuit analyzed the law of Kansas on railroad property interests and quoted extensively from Western Union Telegraph Co. v. Pennsylvania Railroad Co., noting that:

A railroad's right of way has, therefore, the substantiality of the fee, and it is private property, even to the public, in all else but an interest and benefit in its uses. It cannot be invaded without guilt of trespass. It cannot be appropriated in whole or part, except upon the payment of compensation. In other words, it is entitled to the protection of the Constitution, and in the precise manner in which protection is given. It can only be taken by the exercise of the powers of eminent domain. ${ }^{185}$

Although the state courts have not extensively debated whether the railroad right-of-way fits within the traditional estates of fee simple, defeasible fees, or easements or the niceties of corporeal and incorporeal hereditaments, they have spent a significant amount of time actually interpreting deeds to convey either easements or fees simple absolute. ${ }^{186}$ State courts commented frequently that the railroad's right was the same "whether it be characterized as an 'easement' or 'right-of-way," and that, even though the deed purported to convey fee title, only

183. Wyoming v. Udall, 379 F.2d 635, 640 (10th Cir. 1967).

184. See generally Korpela, supra note 111 (summarizing railroad title cases).

185. 195 U.S. 540,570 (1904).

186. See, e.g., Davis v. MCI Telecomm. Corp., 606 So. 2d 734, 738 (Fla. Dist. App. Ct. 1992); State v. Union Electric Co.. 148 S.W.2d 503 (Mo. 1941). The most thorough compilation of state cases on this issue appears in Deed to Railroad Company as Conveying Fee or Easement. Korpela, supra note 111. 
an easement would be recognized because of statutory or grant limitations on the property interests the railroads could acquire by condemnation or grant. ${ }^{187}$

In any event, the modern trend is to call a "right-of-way" an "easement," and to construe railroad property rights as easements whenever there are limitations on the grant or purposes to which the land may be put. Even though the courts call the "right-of-way" an "easement," however, they recognize that it is a special easement, unique to the railroad context, which gives exclusive use and possession to the railroad.

\section{B. Exclusivity}

In outlining the scope, burden, uses, duration, and general parameters of the railroad easement, the most important feature seems to be its exclusive character. Unlike all other private easements and most commercial easements, the railroad easement is exclusive as against the fee owner. In non-railroad cases, the fee owner can use the easement located on her land; she may drive on the driveway or have a picnic under the power line poles of a utility easement. The only restraint on the fee owner's use of her own fee is non-interference with the easement owner's use rights in the encumbered land. But this is not the case with a railroad easement or certain other easements in gross for commercial purposes. ${ }^{188}$ Exclusivity, one court explained, "refers to the exclusion of the owner and possessor of the servient tenement from participation in the rights granted, not to the number of different easements in and over the same land." 189 Thus, an exclusive railroad easement allows for exclusion of the fee owner, though the easement owner may permit multiple uses on the land so long as those uses do not exceed the reasonable limitations on scope or burden of the use.

For the federal railroad grants, the easements are deemed to be "a right in perpetuity to exclusive use and possession." ${ }^{190}$ The reasons for the exclusivity of the railroad easement are many. As the Eighth Circuit explained:

The railroad, charged with the performance of public duties which it cannot evade, and with liabilities which it cannot limit, should, for its own protection as well as in the interest

187. Davis, 606 So. $2 \mathrm{~d}$ at 738.

188. See Henley v. Continental Cablevision, Inc., 692 S.W.2d 825 (Mo. Ct. App. 1985).

189. Davis, 606 So. $2 \mathrm{~d}$ at 828.

190. Wyoming v. Udall, 379 F.2d 635, 640 (10th Cir. 1967). 
of the public, be accorded the free use of its right of way, undisturbed by the claims of adjoining owners to a partial occupancy or use.... An easement granted to a railway is essentially different from any other. The nature of railway service requires exclusive occupancy. A railroad company is held to the highest degree of care, and the exercise of this care necessarily requires that it should have complete dominion over its right of way. It is bound to prevent obstructions from being placed on its tracks, and is required to keep them fenced in, and free from rubbish or other combustible materials. The duties of a railway company are due to the public as well as to individuals, and these duties it must perform at its peril. The rules which apply to the use of streets or highways fail, when applied to railroads, because the necessities of their use are different. The railroad must have the exclusive possession and control of the land within the lines of its location, and the right to remove everything placed or growing thereon, which it may deem necessary to remove to insure the safe management of its road. ${ }^{191}$

To give security to their passengers and workmen and to discharge their duties as public carriers, railroads are held to the highest accountability in the performance of their duties and therefore require unquestioned exclusivity with regard to physical control over the corridor. ${ }^{192}$ Consequently, a railroad company may bring an action in ejectment, which is unique among easement holders. ${ }^{193}$ Moreover, because the easement is exclusive, servient landowners who desire private grade crossings must seek approval from the railroad even though they own the underlying fee. ${ }^{194}$ Even unauthorized use of the grade crossing over a period of time will not entitle the servient landowner to prescriptive rights; the railroad does not own the fee, and it is only the fee owner against whom adverse possession can be acquired. ${ }^{195}$ So long as the railroad continues to maintain the road, the owner of the servient estate has no right to use or occupy the surface of the land burdened by the easement without the railroad company's consent.

191. Midland Valley R.R. Co. v. Sutter, 28 F.2d 163, 166 (8th Cir. 1928) (citations omitted).

192. See C. Clarke, Real Covenants and Other INTERESTS Which 'Run With LAND' INCLUDING LICENSES. EASEMENTS, PROFITS, EguitaBle RESTRICTIONS AND RENTS 83-84 (2d ed. 1947).

193. See Comment, Railroad Right of Way-Nature of the Interest-EasementsEjectment, 30 OR. L. REV. 380, 380-84 (1951); see also BRUCE \& ELY, supra note 126, $\S 1.06[3]$.

194. See Puett v. Western Pac. R.R. Co., 752 P.2d 213, 217 (Nev. 1988).

195. See id. at 215. 
It follows that, if the servient estate owner has no right to use or occupy the railroad's easement, she may not authorize a third party to do so. Exclusivity is equally strict as against the servient owner as against assignees, licensees, lessees, or secondary easement holders. Ironically, while the courts are consistent in stating that a railroad easement is exclusive as against the servient estate owner, a small handful of states have allowed very limited landowner use of unused portions of a railroad easement, a doctrine we call the "landowner-use rule."196 But even in these states, landowners are not permitted to construct permanent structures in the unused portions of the easement, ${ }^{197}$ drill for oil or gas in the easement, ${ }^{198}$ or even enclose pasture land by a fence in a way that might give rise to a claim against the railroad for adverse possession. ${ }^{199}$ Furthermore, in the states applying the landowner-use rule, landowners were permitted to use or occupy portions of railroad corridors only when the railroads had abandoned those portions under state law, ${ }^{200}$ when the railroads had essentially waived their rights to complain about trespasses by allowing continuing infringement by others, ${ }^{201}$ when the railroads had maintained private grade crossings and therefore would be liable for injury caused thereon, ${ }^{202}$ or when the deeds to the railroads reserved for landowners certain uses on the easement. ${ }^{203}$ Hence, even in the states that purport to follow the landowner-use rule, the uses are usually limited to agricultural uses or uses that do not interfere with the railroads. ${ }^{204}$ Moreover, later cases diminish the strength

196. These states - North Carolina, South Carolina, Kansas, and Tennesseeoften recite a rule that sounds relatively broad, but the cases do not bear out the full extent of the rule. The rule is often articulated as "the owner of the fee in a railroad right of way has the right to use so much thereof as is not in the actual use and occupancy of the railroad company, provided the use be not inconsistent with the claim of right of way for the railroad purposes." Atlanta \& Charlotte AirLine Ry. Co. v. Limestone-Globe Land Co., 96 S.E. 188, 190 (S.C. 1918); see also, e.g., Midland Valley R.R. Co. v. Corn, 21 F.2d 96 (D. Kan. 1927); Harvey v. Missouri Pac. R.R. Co., 207 P. 761 (Kan. 1992); Atlantic Coast Line R.R. v. Bunting, 84 S.E. 1009 (N.C. 1915); Mobile \& Ohio R.R. Co. v. Donovan, 58 S.W. 309, 312 (Tenn. 1900).

197. Southern Ry. Co. v. Vannet, 216 S.W. 727 (Tenn. 1919).

198. See Kansas City So. Ry. Co. v. Marietta Oil Corp., 102 F.2d 603 (5th Cir. 1939); Midland Valley R.R. Co. v. Jarvis, 29 F.2d 539, 541 (8th Cir. 1928); Consumers Gas Trust Co. v. American Plate Glass Co., 68 N.E. 1020 (Ind. 1903).

199. See Southern Ry. v. Beaudrot, 41 S.E. 299, 299 (S.C. 1902).

200. See Midland Valley R.R. Co. v. Corn, 21 F.2d 96 (D. Kan. 1927).

201. See Atlantic Coast Line R.R. v. Bunting, 84 S.E. 1009 (N.C. 1915).

202. See Miller v. Seaboard Airline Ry., 77 S.E. 748 , 748-49 (S.C. 1913).

203. See Mobile \& Ohio R.R. Co. v. Donovan, 58 S.W. 309, 313 (Tenn. 1900).

204. Even where agricultural uses were allowed in the easement, the railroad was not held liable for damages to crops within the easement caused by spraying of weed 


\section{of the landowner-use rule, and even those states that had adhered to it at the beginning of the century had shifted to the strict exclusivity rule by mid-century. ${ }^{205}$ Under the strict}

control chemicals by the railroad. See Bivins v. Southern Railway Co., 102 S.E.2d 128,133 (N.C. 1958).

205. See Bivins v. Southern Ry. Co., 102 S.E.2d 128 (N.C. 1958). The only recent cases that purport to follow the landowner-use rule are two questionable decisions from the late 1970s regarding the rights of servient estate owners to authorize location of coal slurry pipelines across railroad easements. See Energy Transp. Sys., Inc. v. Union Pac. R.R. Co., 606 F.2d 934 (10th Cir. 1979) (ETSI X); Energy Trans. Sys., Inc. v. Union Pac. R.R. Co., 619 F.2d 696 (8th Cir. 1980) (ETSI VIIn. Although the courts allowed the servient landowners to authorize use by the coal company against the railroad's wishes, the discussion focused not on the issue of exclusivity but entirely on surface versus subsurface rights in a railroad easement and ownership of the minerals underlying the easement, an issue not particularly contentious. The fee owner is always held to have retained the mineral rights under railroad easements. See, e.g., United States v. Union Pac. R.R. Co., 353 U.S. 112, 120 (1957). It was primarlly the mineral rights issue that caused the federal courts to adjust their interpretation of federally granted rights-of-way as limited fees or easements. For a thorough analysis of the law governing federally granted rights-ofway, see generally ROOT, supra note 57.

In the ETSI cases, it seems important that the pipeline's interference with the railroad easement would be minimal, as it merely transversed the easement and did not lie parallel to it. One motivation for the decision may be that Union Pacific had routinely allowed other pipelines to cross the corridor and merely objected to this one because it directly competed with Union Pacific.

Notably, the courts did not engage the question of how the surface owner might be able to restrict access to the subsurface until abandonment, even though it could not authorize removal of minerals itself. That issue was extensively discussed by the Supreme Court of Indiana in Consumers Gas Trust Co. v. American Plate Glass Co., 68 N.E. 1020 (Ind. 1903). In Consumers Gas Trust Co., the court acknowledged that even though the railroad did not own the mineral estate, it could prevent a lessee of the servient owner from tapping into it by virtue of its exclusive control over the surface. See id. at 1021 ; see also Midland Valley R.R. v. Sutter, 28 F.2d 163 (10th Cir. 1928); Plattner \& Johannson, Railroad, Grants, and Condemnation: Title and Interest Acquired in Railroad Rights-of-Way, 37 N.D. L. REV. 266 (1961). The servient owner would simply have to wait to extract the minerals until the railroad abandoned or gave a license to allow the access.

Because the ETSI cases are of questionable logic and authority, and because they rely on the 1875 Act railroad grants rather than private grants, they have not been followed in any later cases. Moreover, the vitality of these cases is questioned in the Tenth Circuit decision in Missouri-Kansas-Texas R.R. Co. v. Early, 641 F.2d 856 (10th Cir. 1981), in which the court held that Union Pacific had acquired a fee interest in the land, therefore including the mineral rights, in a situation indistinguishable from the grants in ETSI VIII and ETSI X. The only deviation from the rule announced in Consumers Gas Trust, that the mineral estate holder must wait until abandonment if the surface easement holder denies access, was in MissouriKansas-Texas R.R. Co. v. Freer, 321 S.W.2d 731 (Mo. Ct. App. 1958), in which the grantor had reserved in the deed the right to mine on the railroad's easement.

Arguably, this is what happened in the ETSI cases. The landowner-use language was a readily available rule which the court used to justify punishing the railroad for its anti-competitive and discriminatory behavior. The court turned to a short-hand rule of very limited application which conceivably was not intended to apply to such a case rather than decide against the railroad on the grounds that its 
exclusivity rule, even growing crops or permitting livestock to graze along the easement is strictly forbidden. ${ }^{206}$

It is unclear whether the landowner-use rule still has any vitality in light of the 1928 Eighth Circuit decision in Midland Valley R.R. Co. v. Sutter. ${ }^{207}$ That decision was one in a lengthy series of disputes between the railroad, which had leased certain portions of its easement to a company that was drilling for gas and had placed a gas pipeline along the railroad corridor, and the servient landowner, who had granted mineral rights to another gas company who sought to drill on the railroad easement as well. In deciding the issue, the Eighth Circuit went through a lengthy discussion of the landowner-use rule, noting that the

decisions of the national courts and of a majority of the state jurisdictions . . . are to the effect that the railroad company is entitled to the exclusive use and possession of its right of way, and that the owner of the servient estate has no right to occupy the surface of the land conveyed for right of way, in any mode, or for any purpose, without the railroad company's consent. ${ }^{208}$

Besides being the majority view, and more in line with the nature of the railroad easement in light of its public carrier duties, the court in Sutter effectively nullified the minority rule with regard to interstate carriers, at least, under a theory of federal preemption. ${ }^{209}$

denial of permission to cross its track was because the coal slurry pipeline directly competed with the railroad and was not based on legitimate reasons, since it allowed other pipelines to traverse its tracks. See Randall Napier, Coal Slurry Pipelines and Railroad Crossings: Court Decisions Favor the Pipeline Sponsors, 18 Hous. L. REv. 1075 (1981).

206. See Chicago Great Western R.R. Co. v. Zahner, 177 N.W. 350, 351-52 (Minn. 1920); Wilmot v. Yazoo \& Miss. Valley R.R. Co., 24 So. 701, 702 (Miss. 1899).

207. 28 F.2d 163 (8th Cir. 1928).

208. Id. at 165 (citing cases that follow the strict exclusivity rule from Minnesota, Mississippi, Vermont. Pennsylvania. Indiana, New York, Connecticut, Illinois, and Alabama).

209. As the court noted:

We are inclined to the view that the question is one of general jurisprudence, and that we are not bound to follow the Kansas decisions. An interstate commerce railway system adequate to the country's needs is today recognized to be a national necessity. ... In order to provide such a system, recognized safety measures must be followed in the maintenance of the roadbed and right of way. The railroad company is engaged in interstate commerce. It serves, not only residents of Kansas, but people generally throughout the country. It is enjoined to exercise a high degree of care by general law. In addition to this, it is subject to certain regulations and requirements by the Interstate Commerce Commission with reference to safety in the maintenance of its right of way and the operation of its trains. 
The landowner-use cases are not only in the minority because they contravene the exclusivity rule, but also because they have virtually disappeared through the preemption of Sutter and general disuse. The few cases that allowed the servient landowner some limited access to the surface of the easement arose in special circumstances such as waiver, reservation of the right in the grantor, or limited agricultural uses. ${ }^{210}$ But although most courts have seen clearly that the issue is one of exclusivity, and that possession of the mineral estate, for example, simply has to wait until the railroad use ceases, a few recent cases articulated the issue in terms of ownership of certain quantitative physical dimensions of the land rather than the qualitative rights to engage in particular uses. ${ }^{211}$ This view of a railroad easement is unsatisfactory. Railroad easement use simply cannot be viably limited by physical dimension, and simplistic legal analysis muddies the area further. ${ }^{212}$ At the very least, however, the courts are unanimous that a railroad easement, even though it is the weakest property interest available to the railroads, entails exclusive control over the surface of the easement, and extends to include possible future use even when the railroad is using only a portion of the easement. ${ }^{213}$

The basic reason for the majority rule is that exclusive possession is necessary to enable the railroad company to safely conduct its business and meet the duty of exercising that high degree of care which the general law and administrative rules enjoin upon it. In the performance of those duties, imposed by general law and a national administrative tribunal for the public welfare, it should not be hampered by interference through the use of its right of way by the owners of the servient estate, although such use might be justified under the principles announced in local decisions. . . It follows, therefore, that the principles of general law rather than local decision should determine the character of the rights of way granted in the instant case. Regard for the welfare of the public, the patrons, and the employees of the railroad company, in our opinion, compels such a conclusion.

Id. at 167-68. This case effectively reversed the earlier decision in Midland Valley R.R. Co. v. Corn, 21 F.2d 96 (D. Kan. 1927). That same year, in another case involving the same set of players, the Eighth Circuit followed Sutter without a lengthy repetition of the necessity for the strict exclusivity rule. See Midland Valley R.R. Co. v. Jarvis, 29 F.2d 539 (8th Cir. 1928).

210. See Atlantic Coast Line R.R. v. Bunting, 84 S.E. 1009 (N.C. 1915) (waiver); Mobile \& O.R. Co. v. Donovan, 58 S.W. 309 (Tenn. 1900) (reservation in deed); Atlanta \& C.A.L. Ry. Co. v. Limestone-Globe Land Co., 96 S.E. 188 (S.C. 1918) (agricultural uses).

211. See, e.g., ETSI VIII, 619 F.2d 696 (8th Cir. 1980); ESTI X, 606 F.2d 934 (10th Cir. 1979); Missouri-Kansas-Texas R.R. Co. v. Freer, 321 S.W.2d 731 (Mo. Ct. App. 1958).

212. See supra note 205.

213. This rule extends so far that a servient landowner could not engage in 


\section{Physical Dimensions of the Easement}

Although every state conceives of the easement in terms of physical boundaries - width, depth, height, and length - few states limit their analyses of railroad easements to these dimensions. Some states emphasize the physical boundaries of the easement, ${ }^{214}$ while others emphasize the easement holder's use. ${ }^{215}$ For the former, encroachments of the appropriate boundaries cause conflicts that are easily resolved. Did the servient landowner's livestock trespass onto the railroad's easement? Did the railroad's wheels cause sparks that flew beyond the boundaries of the easement?

The states that define an easement by its use find encroachments more difficult to analyze because the courts often must ask whether multiple uses can be consistent with one another. ${ }^{216}$ In some cases, multiple use is simply not possible. Where the servient landowner owns the mineral estate under the easement, but the railroad has exclusive control of the surface, the servient landowner may be able to extract the minerals from wells or mines only if access points are located outside the easement. If she cannot do so, then she may have to wait until the railroad has abandoned its easement before she can enter and extract her mineral property. ${ }^{217}$ Even where the courts view the scope of the easement in terms of the railroad's use, physical dimensions are still relevant. Almost any court analyzing an

excavation along an easement that had been abandoned and converted to a recreational trail through the federal process of railbanking, which preserves rail corridors for possible future reactivation, even though the excavation did not hamper the trail. The Preseault Court reasoned that the federal policy of preserving rail corridors required that servient landowners be held to that standard, even when the corridor was currently being subjected to a less-burdensome use. State v. Preseault, 652 A.2d 1001 (Vt. 1994).

214. See, e.g., Bivens v. Southern Ry. Co., 102 S.E.2d 128, 133 (N.C. 1958) (noting that spraying outside the width of the easement would subject railroad to liability even though it is entitled to spray weeds within easement ).

215. See, e.g., Farmers Grain \& Supply Co. v. Toledo Peoria \& W. R.R., 44 N.E.2d 77 (IIl. App. Ct. 1942) (holding that railroad's airspace rights would be limited to the kind of use regularly made on this particular railroad and the freight regularly carried and would not be extended because of an unusual need that might arise to carry taller freight).

216. See, e.g., Consumers Gas Trust Co. v. American Plate Glass Co., 68 N.E. 1020 (Ind. 1903) (concerning fee owner's lease of the fee for a pipeline); Williams v. New-Albany \& Salem R.R. Co., 5 Ind. 111 (Ind. 1854) (concerning livestock injuries); Kershaw Motor Co. v. Southern Ry. Co., 134 S.E. 377 (S.C. 1926) (concerning injuries to an automobile trespassing on the easement).

217. See, e.g., Consumers Gas Trust Co. v. American Plate Glass Co., 68 N.E. 1020 (Ind. 1903) (preventing servient owner's lessee from drilling on railroad's rightof-way). 
easement must inquire into the width, depth, and height of the easement.

The width of the corridor is a creature of the grant or deed language, and the law encompassing it has been relatively uncontroversial. ${ }^{218}$ Similarly, very few cases have addressed the height of the corridor, while those cases that have addressed height usually involve the ancillary concern of the aesthetic rights of servient landowners to a clear view, which has been obstructed by telephone and electric lines and poles. ${ }^{219}$ The railroad corridor depth, on the other hand, creates fierce litigation when valuable mineral deposits exist under the corridor to which many parties assert rights. ${ }^{220}$ Additionally, parties assert rights to the non-mineral subsurface of the railroad corridor because this land is valuable to utilities, who use the subsurface of the linear corridor to locate pipelines and cables, and to servient or abutting landowners, who may wish to cross the corridor with pipelines or electric wires to serve the land on the other side of the tracks. ${ }^{221}$ The subsurface issue is sometimes confounded with drainage issues where the railroad embankment may have altered drainage patterns in an area and servient landowners desire culverts or livestock tunnels to link land that was bisected by a railroad bed. ${ }^{222}$

\section{Width}

The width of a railroad corridor is spelled out either by a grant (where railroads received the corridor by grant from the federal government or from a state or municipality) or by a deed (where railroads purchased land directly or acquired it through eminent domain proceedings). A land grant to the railroad by Congress or by a state, no matter what property interest the railroads took in the land, specifies the width of the rail corridor, which is usually one hundred or two hundred feet. ${ }^{223}$ Where the railroad purchased a property interest from a landholder directly,

218. See infra Part III.C.1 (discussing width boundaries).

219. See infra Part III.C.2 (discussing height boundaries).

220. See infra Part III.C.3 (discussing depth boundaries).

221. See infra Part III.C. 4 (discussing fiber optics).

222. See, e.g., Touchberry v. Northwestern Ry. Co., 70 S.E. 424 (S.C. 1911).

223. See, e.g., Act of July 27, 1866, ch. 278, 14 Stat. 292 ("TT) right of way through the public lands be, and same is hereby, granted to the said Atlantic and Pacific Railroad Company, its successors and assigns, for the construction of a railroad ... [s]aid way is granted to said railroad to the extent of one hundred feet in width on each side of said railroad where it may pass through the public domain." (emphasis added)). 
or took an interest by eminent domain, the deed granting the corridor to the railroad specifies the physical width measurement of the railroad corridor and may also include the metes and bounds description of the strip in relation to the rest of the grantor's land. ${ }^{224}$

Unlike state and federal grants, deeds from individual landowners occasionally do not specify the width of the railroad corridor that is granted. This may even occur in eminent domain proceedings. In these cases; presumptions are made as to the intended width. One such presumption is that the width of the railroad corridor is equal to the amount the railroad could receive through condemnation. ${ }^{225}$ Another presumption has been to impose the statutory width granted in the railroad's charter. ${ }^{226}$ Courts may look beyond the four corners of an ambiguous deed to extrinsic evidence, such as the erection of telephone poles and fences, valuation maps of railroad properties prepared pursuant to Interstate Commerce Commission requirements, and testimony given by railroad employees to determine the width of the railroad's easement. ${ }^{227}$

A railroad engaged in activities just outside the width of the corridor and on the property of an abutting landowner or servient estate is guilty of trespass, as is the abutting landowner or servient owner who engages in activity within the railroad corridor. ${ }^{228}$ When a railroad sprays weed killers and pesticides

224. See Tazian v. Cline, 686 N.E.2d 95, 96 (Ind. 1997).

[S]aid parties ... do grant and convey and warrant . . . a strip of land fifty feet in width on West side of railroad over, across, and through the following described tract of land situated in the county of Allen and State of Indiana, viz.: The South West guarter of Section Two (2). Township Thirty-one (31) North. Range Twelve (12) East, formerly owned by William ... Hawley deceased deeded by Wm. E. Hawley to S.C. Evans recorded record 55, page 438 said strip of ground to be on and along the central line of said railroad as the same shall be finally located on such tract of land and of such width on each side of said central line as the final location of said railroad by said company shall determine.

Id. at 96.

225. See Brown v. Alabama Great So. R.R. Co., 544 So. $2 d 926$ (Ala. 1989). As the Brown Court noted, "In any event, in Alabama Midland Ry. v. Brown, 98 Ala. 647, 13 So. 70 (1893), we recognized that a grant of a railroad right-of-way of a non-specified width should be construed as 'not exceeding 100 feet,' as that was the width that a railroad company could acquire through condemnation." Id. at 928.

226. See Southern Ry. Co. v. Vann, 216 S.W. 727, 729 (Tenn. 1919).

227. See, e.g., Stevenson v. St. Louis Iron Mountain \& S. Ry. Co., 188 S.W. 832 (Ark. 1916) (holding that deed to railroad without width easement conveys to telephone poles only); Illinois Cent. R.R. Co. v. Taylor, 175 S.W. 26 (Ky. 1915) (holding that deed lacking width conveys easement to established fenceline).

228. See infra notes 224-25. 
along its easement, it will be liable for harm to the servient landowner's crops outside the easement, but not those within the easement. ${ }^{229}$ Conversely, a landowner will be guilty of trespass even for growing crops within the easement because the railroad has rights to exclusive possession of the easement surface for the requisite width..$^{230}$

Sometimes a servient landowner's concurrent use of unused portions can give rise to a claim in adverse possession. Clearly, the servient owner cannot adversely possess against an easement owner because the servient owner already has title to the land at issue. ${ }^{231}$ But some courts will allow an adverse and non-permissive use by the servient owner for the statutory period to ripen into an unburdening of the servient estate. ${ }^{232}$ The majority rule states, however, that any adverse use, even against currently unused portions of an easement, is contrary to public policy; the railroads have public carrier duties and may need to expand onto currently unused land at some later date. ${ }^{233}$ Conversely, a railroad can only rarely adversely possess against adjoining landowners. Where the railroad constructed its roadbed without obtaining written title to the land or to an easement, any adverse use will be limited to the extent of the actual use. ${ }^{234}$ Similarly, the adverse use most often will give rise only to a prescriptive easement, not fee simple title, because the railroad is deemed to need only an easement. ${ }^{235}$

A governmental entity that condemns part of a railroad corridor must pay for the entire width of the corridor, even

229. See Bivens v. Southern Ry. Co. 102 S.E.2d 128 (N.C. 1958).

230. See Chicago Great Western R.R. Co. v. Zahner, 177 N.W. 350, 351 (Minn. 1920).

231. See Puett v. Western Pac. R.R. Co., 752 P.2d 213, 215 (Nev. 1988).

232. See Wilmot v. Yazoo \& Miss. Valley R.R. Co., 24 So. 701, 702 (Miss. 1899).

233. See, e.g., Allard Cattle Co. v. Colorado \& S. Ry. Co., 530 P.2d 503 (Colo. 1974); Southern Ry. v. Beaudrot, 41 S.E. 299 (S.C. 1902); Southern Ry. Co. v. Vann, 216 S.W. 727, 731 (Tenn. 1919); Mobile \& Ohio R.R. Co. v. Donovan, 58 S.W. 309 (Tenn. 1900).

234. See Hoffman v. Zollman, 97 N.E. 1015, 1017 (Ind. Ct. App. 1912); St. Louis S.W. Ry. Co. v. Davis, 87 S.W. 445, 446 (Ark. 1905). But see Waggoner v. Wabash R.R. Co., 56 N.E. 1050 (Ill. 1900) (allowing a larger tract of land to be acquired by adverse possession than that actually used).

235. See Consumers Gas Trust Co. v. American Plate Glass Co., 68 N.E. 1020 , 1021 (Ind. 1903). Some states have altered this by statute. Ironically, South Carolina, a state that strongly protects landowners against the railroads, passed a statute in 1845 that provided that if a railroad entered land without obtaining title, built its road, and occupied it for two years without the landowner complaining, that railroad's title would ripen into a fee simple. See 1845 S.C. Acts 2953, §11; Eldridge v. City of Greenwood, 388 S.E.2d 247, 248 (S.C. Ct. App. 1989) (acknowledging fee simple deeds in an 1845 statute). 
portions that are currently unused by the railroad. ${ }^{236}$ Because of the possible future needs of the railroad, any adverse claims against it should be limited, and the railroad's interests in the entire width should be protected against encroachments by landowners and condemnation by governmental entities. ${ }^{237}$ At the same time, when the railroad adversely possesses against a landowner, the interest taken and the corresponding width of the corridor should be the minimum necessary for the safe and reasonable operation of the road, even if that width is greater than that actually occupied by the tracks and ties.

\section{Height}

Railroads generally have exclusive air rights over the railroad corridors $^{238}$ and, in most states, exclusive rights to grant leases or licenses to utility companies to place poles and wires in their easements. ${ }^{239}$ The servient landowner may not recover for potential aesthetic injury, nor may she recover when the poles reach higher than the trains that pass through the airspace. ${ }^{240}$

Furthermore, electric and telecommunications companies generally have statutory power to condemn easements along railroad corridors, regardless of the railroads' property interests. $^{241}$ This condemnation power is limited to uses compatible with the railroads. Some statutes, for example, require that the utility lines be located a minimum distance from the centerline of the railroad tracks. ${ }^{242}$

236. See People ex rel. Dep't of Transp. v. Southern Pac. Transp. Co., 148 Cal. Rptr. 535 (Cal. Ct. App. 1978).

237. See, e.g., Graham v. St. Louis, Iron Mountain \& S. Ry. Co., 65 S.W. 1048 (Ark. 1901); Minneapolis \& St. L. Ry. Co. v. Village of Hartland, 88 N.W. 423 (Minn. 1901); West Va. Bd. of Regents v. Fairmont, Morgantown \& Pittsburgh R.R. Co., 189 S.E.2d 40 (W. Va. 1972).

238. See Chicago Union Station Co. v. Korzen, 422 N.E.2d 62 (Ill. App. Ct. 1981).

239. See Mobile \& Ohio R.R. v. Postal Tel. Cable Co., 46 S.W. 571 (Tenn. 1898).

240. See Central of Ga. Ry. Co. v. Lawley, 126 S.E. 273 (Ga. Ct. App. 1925); see also Unsightliness of Powerlines, supra note 47. In Lawley, the railroad was held not liable for injuries to highway workers installing an overpass over a railroad track but under a high-voltage electric line in the railroad corridor. The railroad was held to have the power to grant to the electric company the right to place the high-voltage lines even though the lines obviously reached higher than the needs of the train, as the railroad acquiesced in construction of a highway bridge between the tracks and the electric lines. See Lawley, 126 S.E. at 274.

241. See Northern Pac. Ry. Co. v. North Am. Telegraph Co., 230 F. 347 (8th Cir. 1915); Ohio Edison Co. v. Consolidated Rail Corp., 486 N.E.2d 103, 105 (Ohio. Ct. App. 1984); Davis v. MCI Telecomm. Corp., 606 So. 2d 734, 737 (Fla. Dist. App. Ct. 1992).

242. See, e.g., Ky. REv. STAT. ANN. \& 175.590 (detailing special provisions for condemning railroad property). 
The railroads' exclusive control over the use and occupation of the surface of the land entitles them to damages when their property interests are invaded. ${ }^{243}$ In a utility condemnation, the railroad, not the owner of the servient land, is entitled to compensation. This suggests that the scope of the railroad's easement includes the utility subeasement or license. Railroads are also entitled to damages in eminent domain when an aerial easement is taken against their will. ${ }^{244}$ Railroads have been compensated for aerial easements taken for elevated train use, crane use, and elevator use, as well as utility use. ${ }^{245}$ The West Virginia Supreme Court has concluded that a railroad's airspace should be limited to the height of the lowest tunnel regularly used, but the court noted that if the railroad can show that it "reasonably intends to employ new technology which will, in the foreseeable future, cause its airspace to be of greater than nominal value to it," it will be entitled to compensation for encroachments on that larger airspace. ${ }^{246}$

Airspace rights create the same difficulty as subsurface rights. If the railroads have exclusive control over the surface, the servient landowner simply cannot permit third-party users to trespass into the airspace or subsurface of the land. Moreover, since the railroads often contracted for telegraph services and included in their contracts provisions that upon abandonment by the telegraph company the poles and wires would become the personal property of the railroad, the railroads have reasonable claim to the airspace rights over their corridor for electric or telecommunications use.

\section{Depth}

Railroads undeniably have the right to use and occupy the surface of the railroad easement but generally do not have the right to extract the minerals underlying the easement. ${ }^{247}$ However, the extent to which railroads (and others) may use and

243. See Dep't of Transp. v. Southern Pac. Transp. Co., 148 Cal. Rptr. 535 (Cal. Ct. App. 1978) (involving takings issue).

244. See West Va. Bd. of Regents v. Fairmont Morgantown Pittsburgh R.R. Co., 250 S.E.2d 139, 145 (W. Va. 1978).

245. See Farmers Grain \& Supply Co. v. Toledo, P.\&W. R.R., 44 N.E.2d 77 (Ill. App. Ct. 1942); Illinois Cent. R.R. Co. v. Centerville Telephone Co., 186 S.W. 90 (Tenn. 1916); Citizens' Telephone Co. v. Cincinnati, N.O. \& T.P. R.R. Co., 233 S.W. 901 (Ky. Ct. App. 1921).

246. West Va. Bd. of Regents, 250 S.E.2d at 145.

247. See Midland Valley R.R. Co. v. Sutter, 28 F.2d 163, 164 (8th Cir. 1928); Consumers Gas Trust Co. v. American Plate Glass Co., 68 N.E. 1020 (Ind. 1903). 
occupy the non-mineral sub-surface of the railroad corridor is uncertain because most states articulate the railroads' property rights in terms of use, not physical dimensions. ${ }^{248}$ Hence, where telegraph lines are necessary to send signals to upcoming stations, the presence of telegraph poles and wires clearly constitutes a railroad purpose within the scope of the easement, regardless of whether they are above ground or buried beneath the surface of the corridor. ${ }^{249}$

Unless they hold title in fee simple absolute or fee simple determinable, railroads generally do not have the right to extract minerals underlying the railroad corridor, whether they acquired their corridors from a private landowner by adverse possession or from a federal grant. ${ }^{250}$ In the leading case on federal grants, United States $v$. Union Pacific, ${ }^{251}$ the Supreme Court held that the Union Pacific Railroad Company did not acquire the mineral rights to the lands underlying the right-of-way granted in the Pacific Railroad Act, ${ }^{252}$ even though the grant was construed to pass a limited or defeasible fee. ${ }^{253}$ The court so held for three reasons. First, drilling for minerals under the railroad right-ofway was deemed not a "railroad purpose" within the meaning of the Act, which had granted the land to the railroad for "railroad purposes." 254 Second, Section 3 of the Act excepted "mineral lands" 255 from the grant of "every alternate section of public land," 256 and the Court found that that exception should apply equally to the railroad corridor itself. ${ }^{257}$ Lastly, the Court found

248. See infra Part III.D.2 (discussing incidental use doctrine).

249. See id.

250. See United States v. Union Pac. R.R. Co., 353 U.S. $112,113-14,118-20$

(1957); Great N. Ry. Co. v. United States, 315 U.S. 262 (1942); Wyoming v. Udall, 379

F.2d 635 (10th Cir. 1967); Midland Valley R.R. Co. v. Sutter, 28 F.2d 163, 164 (8th

Cir. 1928); Consumers Gas Trust Co. v. American Plate Glass Co., 68 N.E. 1020 ,

1021 (Ind. 1903).

251. 353 U.S. 112 (1957).

252. Union Pacific Railroad Act, July 1, 1862, ch. 120, 12 Stat. 489.

253. See Union Pac., 353 U.S. at $118-20$.

254. Id. at 114 ("It would seem that, whatever may be the nature of Union Pacific's interest in the right of way, drilling for oil on or under it is not a railroad purpose.").

255. Id. at 1 15-16 ("It is, therefore, wholly in keeping with the federal policy that prevailed in 1862 , when the present right of way was granted, to construe 'mineral lands' to include mineral resources under the right of way.").

256. It was the practice of Congress at the time of the western railroad grants to give railroads alternating blocks of land along the railroad corridor every ten miles. See Leo Sheep Co. v. United States, 440 U.S. 668, 672 (1979) ("Land surrounding the railroad right-of-way was divided into 'checkerboard' blocks. Odd-numbered lots were granted to the Union Pacific.").

257. See Union Pac., 353 U.S. at 115 ["But the exception in $\S 3$ [which dealt with the alternating land grants adjacent to the right-of-wayl is not limited merely to a few enumerated sections any more than it is limited to $\$ 3$. The proviso makes sense if it 
that it was the policy of the United States to reserve mineral rights for itself. ${ }^{258}$ While United States $v$. Union Pacific technically extends only to the railroad corridors granted by the Pacific Railroad Act, the holding is highly persuasive in any case dealing with the mineral rights of federal railroad grants because that Act is similar to every other pre-1871 federal railroad grant. ${ }^{259}$

The consistency in doctrine regarding mineral rights does not carry over to doctrines regarding non-mineral subsurface rights. To begin with, the cases disagree on how to distinguish the "surface" of a railroad corridor from the "non-mineral subsurface," or "strata" of a railroad corridor. Most courts differentiate "surface" from "subsurface" or "underlying lands," 260 but some have found that "surface" and "subsurface" rights are really the same thing. ${ }^{261}$

Conflict over the subsurface arises in two ways. First, conflict arises when the easement owner grants a subsurface lease or license to a third party, and the servient landowner claims that the use is an additional burden requiring compensation. Second, conflict arises when the servient owner authorizes a third party to use the subsurface of the corridor in a way that interferes with the easement owner's surface use. As discussed above, most states forbid the servient landowner to authorize any third-party use of the corridor. Even the minority landowner-use states allow the servient landowner to grant subsurface easements in narrowly drawn situations. ${ }^{262}$

is read to reserve all mineral rights under the right of way, as well as to reserve mineral lands in the alternate sections of public land granted in aid of the construction of the road.").

258. See id. ("The reservation of the mineral resources of these public lands for the United States was in keeping with the policy of the times.").

259. See Act of Mar. 3, 1871, ch. 122, 16 Stat. 573; General Railroad Right-ofWay Act, Mar. 3, 1875, ch. 152, 18 Stat. 482 (codified at 43 U.S.C. \$ 934 (1994)); Act of July 27,1866 , ch. 278,14 Stat. 292 . If the corridor is held by the railroad in fee simple determinable (as all railroad corridors granted before 1871), the granting party (the federal government) or their successor in interest merely has a future right of possible reversion in the mineral estate as well as in the surface.

260. See Energy Transp. Sys., Inc. v. Union Pac. R.R. Co., 606 F.2d 934 (10th Cir. 1979); Idaho v. Oregon Short Line R.R. Co., 617 F. Supp. 207 (D. Idaho 1985).

261. See United States v. Union Pac. R.R. Co., 353 U.S. 112, 131 (1957) (Frankfurter, J., dissenting) (''Surface' could not, of course, mean merely the area that is seen by the eye. To say that it means the visual area and an indeterminate depth- $x$ inches or $x$ feet- necessary for support is to ask the Court to rewrite legislation and to cast upon it administrative tasks ...."); see also Mellon $\mathrm{v}$. Southern Pac. Transp. Co., 750 F. Supp. 226, 230 (W.D. Tex. 1990) (citing Chugach Natives, Inc. v. Doyon, Ltd., 588 F.2d 723, 728 (9th Cir. 1978)).

262. The ETSI decisions are the exception and, for the reasons stated, are of questionable precedential value. See supra note 205; see also supra notes 200-203. 
The federal courts have stated that federal grants to the railroads are to be construed in favor of the railroads, making it clear that the railroads have the right to use and occupy so much of the non-mineral subsurface of the railroad corridor as is necessary to effectuate the purpose of the grant: operating a railroad. ${ }^{263}$ Undoubtedly, railroads have the right to construct the railroad itself in the easement and may also construct any appurtenances necessary to the operation of that railroad, such as depots, elevated roadbeds, station buildings, water tanks, machine shops, side tracks, and turnouts. ${ }^{264}$ Most of these structures have foundations well below the surface of the corridor. Where railroads need land thousands of feet deepsuch as tunnels burrowed through mountains - they have always had a right to use and occupy it. ${ }^{265}$

Federal administrative interpretations of the statutes also support the railroads. The United States Department of the Interior's Office of the Solicitor issued a memorandum regarding the rights of railroads to the non-mineral subsurface of their corridor land. ${ }^{266}$ In that memorandum, the acting solicitor concluded that in the pre-1871 land grants, the railroads acquired a defeasible fee which did not include the minerals, but did include the non-mineral subsurface. The acting Solicitor concluded that the 1875 easements also included the nonmineral subsurface. An easement usually will not include subsurface rights if they are not distinguishable from mineral rights, but the Department determined that the easement's exclusivity made the railroad's present interest tantamount to fee simple. Moreover, the granting statute did not except the subsurface estate, and the Department's administrative interpretations of the statute recognized subsurface rights in the railroads. Finally, railroad authorization of third-party uses of their corridor is a long-standing custom. ${ }^{267}$ With respect to

263. See Leo Sheep Co. v. United States, 440 U.S. 668, 683 (1979) (quoting United States v. Denver \& Rio Grande Ry. Co., 150 U.S. 1, 14 (1893)) ("ISluch legislation [railroad grants] stands upon a somewhat different footing from merely a private grant, and should receive at the hands of the court a more liberal construction in favor of the purposes for which it was enacted ....").

264. See Denver \& Rio Grande Ry. Co., 150 U.S. at 8.

265. See, e.g., Mcllvaine v. Florida East Coast Ry. Co.. 568 So. $2 \mathrm{~d} 462$ (Fla. Dist. Ct. App. 1990); Norton v. City of Gainesville, 86 S.E.2d 234 (Ga. 1955); Hudson \& Manhattan R.R. Co. v. State Bd. of Tax Comm'rs, 96 N.E. 435 (N.Y. 191 1).

266. See generally PROPOSED INSTALLATION, supra note 121.

267. There is no question that pipe and wire uses both bisect and run longitudinally along nearly every railroad corridor in the country, and many of these lease agreements are a hundred years old or more. To the extent that the law adopts a policy of not disrupting well-settled property expectations, the long-term use of 
federal railroad grants, therefore, the railroads are given wide discretion to authorize third-party uses of their subsurface corridor.

State law is more equivocal, whether the railroads obtained easements by state grant, private deed, eminent domain, or adverse possession. Three recent cases- from Texas, Florida, and Tennessee - have directly addressed the rights of railroad companies to authorize the use of their corridor for laying fiberoptic cable without compensation to the servient landowner. ${ }^{268}$ In only two of the cases was the railroad held to have that power under an easement for railroad purposes. ${ }^{269}$ In a fourth case, a Maryland Court of Appeals held that, when a city condemns a railroad corridor using its power of eminent domain, it need not compensate the railroad for the lost revenues of utility royalties because the railroad "had no right to enter into agreements with utilities for installation of their lines or pipes" and was thus owed no compensation. ${ }^{270}$ Although only one of these cases was decided with reference to the surface/subsurface distinction rather than a generic use rationale, the different outcomes reflect a fundamental difference in the way different courts address the railroad's power to grant utility access on their easements.

In Mellon $v$. Southern Pacific Transport Co. ${ }^{271}$ the District Court for the Western District of Texas held that a railroad may grant a subeasement to a fiber-optic company to lay buried cables in the railroad corridor without compensating the servient owner. ${ }^{272}$ The court cited a series of cases protecting the railroad's rights in the non-mineral subsurface, including a case requiring that the railroad's permission be obtained to locate an underground gas pipeline on the corridor, ${ }^{273}$ a case holding that

these corridors by multiple parties would suggest that the parties, judges, legislators, and lawyers all believed multiple uses were within the scope of the railroad easement.

268. See Mellon v. Southern Pac. Transp. Co., 750 F. Supp. 226, 229-30 (W.D. Tex. 1990) (railroad has power); Davis v. MCI Telecomm. Corp., 606 So. 2d 734 (Fla. Dist. Ct. App. 1992) (railroad has power); Buhl v. United States Sprint Comm. Co., 840 S.W.2d 904, 912 (Tenn. 1992) (no such power). See discussion infra Part III.D.3.

269. See id.

270. D.C. Transit Systems, Inc. v. State Roads Comm'n, 270 A.2d 793, 800 (Md. 1970). But see Ohio Edison Co. v. Consolidated Rail Corp., 486 N.E.2d 103 (Ohio Ct. App. 1984).

271. 750 F. Supp. 226 (W.D. Tex. 1990).

272. See id. at 231 ("This Court finds the right-of-way surface includes the nonmineral topsoil that would be occupied by a buried fiber optic line, and the fiber optic cable is an authorized incidental use which is not inconsistent with railroad uses and does not burden the subservient estate retained by the Plaintiff.").

273. See Lo-Vaca Gathering Co. v. Missouri Kan.-Tex. R.R. Co.. 476 S.W.2d 732, 739 (Tex. Civ. App. 1972). 
the subsurface estate refers to the mineral estate while the surface estate refers to the remainder of the non-mineral estate including subsoil, ${ }^{274}$ and a case holding that the railroad could not make any use of the mineral estate but could authorize uses of the remainder of the right-of-way. ${ }^{275}$ The Mellon court found that the "right-of-way surface includes the non-mineral topsoil that would be occupied by a buried fiber-optic line."276 In essence, the Mellon court seems to have followed the customary real property distinctions between surface and mineral estates. ${ }^{27}$

Two years later, a Florida court of appeals resolved a similar dispute between MCI and servient landowners. Applying a state statute authorizing telephone and telegraph lines on railroad rights-of-way, the court found that the placement of fiber-optic lines in the corridor's subsurface imposed no additional servitude. ${ }^{278}$

That same month, however, the Supreme Court of Tennessee, a state that has traditionally adopted the landowneruse rule, ruled against Sprint Communications and in favor of servient landowners on similar facts in the $M C I$ case. ${ }^{279}$ But even the Tennessee court stated that under the railroad easement, "The company has the free and perfect use of the surface of the land so far as is necessary for all its purposes, and the right to use as much above and below the surface as may be needed."280 At the very least, the surface estate always includes as much subsurface depth as is required to support the surface uses. ${ }^{281}$

In any event, state courts have not consistently defined the terms "surface" and "subsurface," making it impossible to determine the exact depth of any railroad easement. In the majority of states, a railroad easement appears to include everything in the subsurface except the mineral estate because the surface estate requires subjacent support. Only in the minority of states does the depth issue seem to create problems

274. See Chugach Natives, Inc. v. Doyon. Ltd.. 588 F.2d 723, 728 (9th Cir. 1978).

275. See United States v. Union Pac. R.R. Co., 353 U.S. 112 (1957); Great N. Ry. Co. v. United States, 315 U.S. 262, 279 (1942).

276. $750 \mathrm{~F}$. Supp. at 231 .

277. This distinction is drawn usually to guarantee to the owner of the surface estate enough subsurface to provide adequate subjacent support. See CUNNINGHAM ET AL., supra note 77 , at $423-24$.

278. See Davis v. MCI Telecomm. Corp., 606 So. $2 d 734$ (Fla. Dist. Ct. App. 1992).

279. See Buhl v. United States Sprint Comm. Co., 840 S.W.2d 904 (Tenn. 1992); see also D.C. Transit Sys., Inc. v. State Roads Comm'n, 270 A.2d 793 (Md. 1970).

280. Buhl, 840 S.W.2d at 909.

281. A corollary of this conclusion is that the owner of the mineral estate may not remove the minerals if doing so causes the surface to collapse. 
for courts, in part because those states may continue to follow the landowner-use rule. And while landowner control over the mineral estate is hard to reconcile with the exclusivity rule, restricting the courts' focus to the parameters of the use alone does not solve the problem.

The difficulty the courts have had in determining the extent of the railroads' rights in the subsurface are complicated by the ongoing conflation of physical restrictions with use restrictions. A South Carolina court, for example, found that a railroad went beyond the scope of the easement's depth when it permitted another railroad to construct a tunnel underneath its tracks which did not connect to the first railroad's tracks. ${ }^{282}$ Because the competing railroad use was not the railroad use authorized in the original grant, the tunneling was held to be an additional servitude. ${ }^{283}$ Was this an additional servitude on the servient land because the tunnel strayed beyond the railroad use of the easement or because it exceeded the physical depth allowed by the easement? Would it have changed the outcome if the second railroad had simply crossed at grade? Because the court did not specify, it is unclear if the violation was in use or depth, which contributes to the doctrinal confusion in this area.

As a matter of logic and traditional property law, however, the Department of the Interior's position seems the more intelligible rule given the conflicting issues. If a railroad has exclusive control over the surface, and presumably enough subsurface to guarantee subjacent support, it would seem to have the right to authorize utility use within the physical domain encompassed by those rights, which would certainly include the three or four feet necessary to lay a fiber-optic cable. Thus, exclusivity and subjacent support rights would favor the railroad. In addition, because the railroad has exclusive rights to the surface, the fee owner would not be entitled to authorize a trespass by a utility company onto the surface of the railroad's easement for construction and laying of the cable. On the other hand, from the perspective of the railroad's "use," the cable may arguably be beyond the scope of the easement.

\section{Scope of the Easement}

The scope of an easement is in part defined by its width, depth, and height: the physical boundaries inside which the

282. See Cayce Land Co. v. Guignard, 134 S.E. 1 (S.C. 1926), cited in Eldridge v. City of Greenwood, 388 S.E.2d 247 (S.C. Ct. App. 1989).

283. See id. 
easement owner may use the land. ${ }^{284}$ Use outside those boundaries constitutes a trespass. But the scope of an easement also includes the kind of use envisioned by the original granting parties, and easements will be limited to any use explicitly stated in the grant. Thus, a driveway easement will be limited to ingress and egress purposes while a utility easement will be limited to the location of utility lines. Whether utility lines could be located on the driveway land depends on how narrowly or broadly the use is interpreted. If ingress and egress are interpreted broadly to include all necessary people and things that must reach the dominant estate, then electricity or phone communications seem as much a part of ingress and egress as the mail delivery person or the ambulance. People must be connected to the outside world, bring certain things into their homes, and take other things out. If an easement is interpreted narrowly to include only vehicular traffic, however, then a homeowner could receive information by mail but not by telephone or email. The central issue for railroad easements is whether or not permitting a utility to jointly occupy the rail corridor is an additional servitude for which the servient landowner should be compensated. Thus, the question becomes whether the granting parties intended the easement to be a multi-use public transportation corridor or a narrowly-defined railroad bed.

\section{Telephone and Telegraph Cases}

Courts have long held that when a railroad company holds a railroad corridor as an easement "for railroad purposes only," and constructs telephone poles and wires ${ }^{285}$ that are used solely to facilitate the operation of the railroad, the telephone poles and wires do not constitute an additional burden or servitude on the underlying fee. ${ }^{286}$ This holding applies whether the railroad or a

284. See BRUCE \& ELY, supra note $112, \S 7.02$.

285. "Telephone lines or wires" as used herein also denotes "telegraph lines or wires."

286. See Right and Measure of Compensation to Owner of Fee when Telegraph or Telephone Line Is Erected Along Railroad Right of Way or Highway. 8 A.L.R. 1293 (1920); see also NICHOLs', supra note 11, \$§ 3:11.01[2][e], 5:16.07[4]; Atlantic \& Pac. Tel. Co. v. Chicago, Rock Island \& Pac. R.R. Co., 2 F. Cas. 176 (C.C.N.D. Ill. 1874); Mayor of the City of Canton v. Canton Cotton Warehouse Co., 36 So. 266 (Miss. 1904): Phillips v. Postal Tel. Cable Co., 41 S.E. 1022 (N.C. 1902), rev'd on other grounds, 42 S.E. 587 (N.C. 1902); American Tel. \& Tel. Co. v. Smith, 18 A. 910, $912-$ 13 (Md. 1889); Hodges v. Western Union Tel. Co., 45 S.E. 572 (N.C. 1903); Western Union Tel. Co. v. Rich, 19 Kan. 517 (1878); Pennsylvania R.R. Co. v. Lilly Borough, 56 A. 412 (Pa. 1903): Taggart v. Newport St. Ry. Co., 19 A. 326 (R.1. 1890); St. Louis, Iron Mountain \& S. Ry. Co. v. Cape Girardeau Bell Tel. Co., 114 S.W. 586 (Mo. Ct. 
third party operates the phone line. ${ }^{287}$ Clearly, the railroad must be able to communicate with upcoming stations and trains to monitor traffic and must be able to send signals to switches. But the states differ on whether a telephone company may also use those same rail corridor phone lines to send additional nonrailroad communications.

In the nineteenth century, the original and preferred method of communicating between stations was the telegraph line. ${ }^{288}$ As a result, some railroads constructed and operated their own communications lines while others contracted with Western Union or other telegraph companies to provide this important service. $^{289}$ To make the investment worthwhile, however, most telegraphs expanded to provide communication services to the general public as well. While the railroad industry remained relatively static, the commercial telegraph business exploded in the later decades of the 19th century. As the public use increased, the courts did not view the mixed railroad/public commercial use as presenting any legal problem. As the Ninth Circuit explained in 1914, "[i]n the present age of progress, the telegraph is as essential to the needs and comforts of the public as the railroads themselves." 290

As public telegraph services and communication facilities became public necessities and the railroad corridors were recognized as the most efficient locations for new telegraph lines, Congress and the state legislatures granted eminent domain power to the telegraph companies to force the railroads to allow them access to their corridors. ${ }^{291}$ Furthermore, when competing telegraph companies sought access to the railroad corridor already burdened with one telegraph, the courts uniformly held any exclusivity provisions in the railroad's contract with the established telegraph company void as against public policy. ${ }^{292}$

App. 1908).

287. See, e.g., Cape Girardeau Bell Tel. Co., 114 S.W. at 587 ("[T]he railroad company may construct and maintain such telephone or telegraph line on the right of way for its own purpose, or it may take a partner into the enterprise, or contract with another to erect and maintain the line and furnish the required telephonic or telegraphic service to the end of transmitting intelligence with respect to the operation of it trains, carriage of traffic, passengers and other needs of it calling.").

288. See generally MARTIN, supra note 53.

289. See, e.g., Western Union Tel. Co. v. Postal Tel. Co., 217 F. 533 (9th Cir. 1914); Pacific Postal Tel. Cable Co. v. Western Union Tel. Co., 50 F. 493 (C.C.D. Wash. 1892).

290. Western Union Tel. Co. v. Postal Tel. Co., 217 F. 533, 538 (9th Cir. 1914).

291. See, e.g., Pacific Railroad Act, ch. 120, 12 Stat. 489; Florida 'Telegraph Act' of 1903, ch. 5211, §§ 1, 3, 7; OHIO REV. CODE ANN. § 4931.06 (Banks-Baldwin 1999).

292. See Western Union Tel. Co. v. Postal Tel. Co., 217 F. 533 (9th Cir. 1914); 
The importance of telegraph services and the public benefits of fostering competition justified forcing the railroads to allow multiple telegraph lines on the poles so long as there was no interference with their railroad operations. ${ }^{293}$ Because the lines and poles already existed for railroad purposes, the stringing of additional lines was seen as only a nominal burden, while creating a separate utility corridor for competitors was clearly wasteful and inefficient to the public's need for additional services. A telegraph company that wanted to provide services could do so most efficiently by simply exercising eminent domain against a recalcitrant railroad. ${ }^{294}$

But the overriding question is whether the railroads may authorize telegraph or telephone use on their corridors when the communications use is partly or entirely commercial and not railroad related. ${ }^{295}$ Both because the railroads brought the telegraph to rural areas, and because the railroads were forced to allow competing telegraph companies access to the corridors, the majority rule has been that telegraph lines (and their modern equivalent, telephone lines) are fully consistent with an easement for railroad purposes. ${ }^{296}$ As Judge Sanborn for the Eighth Circuit explained:

A railway company, which has become the owner of a railroad which it is operating and of a right of way appurtenant thereto, has the exclusive right to the use of that right of way for telegraph purposes as well as for railroad purposes. If after the application of so much of the use thereof as the maintenance of its own railroad and telegraph requires there remains a surplus use of that right of way either for telegraph purposes or for railroad purposes, it may lease or permit that use, or any part of it, for a valuable consideration for any purpose which does not interfere with its operation of its own

Pacific Postal Tel. Cable Co. v. Western Union Tel. Co., 50 F. 493 (C.C.D. Wash. 1892).

293. See id.

294. In fact, the Ninth Circuit held that a railroad was unable to grant an exclusive right to one telegraph company under a pre-1871 grant, even though the railroad held a defeasible fee. See Western Union Tel. Co. v. Postal Tel. Co., 217 F. 533 (9th Cir. 1914). Yet the telegraph company had to pay the railroads for the value of the utility easement taken because the right to license telegraph use was seen as a valuable property right inhering in the rallroads. See, e.g., Northern Pac. Ry. Co. v. North Am. Tel. Co., 230 F. 347 (8th Cir. 1915) (holding that the telegraph had to pay railroad for rights it acquired by eminent domain).

295. In some cases, the railroads' independent communications system provided communication access for smaller rural communities. See id. at 276-77.

296. See, e.g., Campbell v. Southwestern Tel. \& Tel. Co., 158 S.W. 1085 (Ark. 1913): Sioux City v. Missouri Valley Pipe Line Co., 46 F.2d 819, 826 (N.D. Iowa 1931) (citing related cases). 
railroad and telegraph and its discharge of its duties to the public so to operate them. This right of a railroad company to lease or permit the surplus use of its right of way, or of its property, is its private property and it is often very valuable property. ${ }^{297}$

In a handful of states - the same states that followed the landowner-use rule to defeat the railroad's exclusivity rightsthe courts have refused to recognize the railroad's rights to grant access to telegraph companies for solely commercial telegraph use. ${ }^{298}$ In Tennessee, the Supreme Court stated that a railroad "cannot license the appropriation of ... such right of way to private business purposes, nor to public purposes, except so far as needful, and helpful to the operation of the road itself."299 Ignoring the exclusivity problem, the court baldly stated that:

[i]t is almost everywhere held that the erection of a line of telegraph over the right of way of a railroad company, not to be used in the operation of the railroad, but for purely commercial purposes, imposes an additional burden on the fee, and the landowner is entitled to additional compensation from the telegraph company. ${ }^{300}$

But this runs counter to the competition cases mentioned earlier because when the court forced a railroad to accept two telegraph company lines on its corridor, the second presumptively was

297. Northern Pac. Ry. Co. v. North American Tel. Co., 230 F. 347, 349 (8th Cir. 1915). This rule is further supported by the common practice that the railroad would acquire title to the poles and wires of any telegraph that abandoned its line. See generally Wilner, supra note 5.

298. See Western Union Tel. Co. v. Nashville, Chattanooga \& St. Louis Ry. Co., 237 S.W. 64 (Tenn. 1922).

299. Mobile \& Ohio R.R. Co. v. Postal Tel. Cable Co., 46 S.W. 571, 572 (Tenn. 1898).

300. Western Unton Tel, 237 S.W. at 65. Likewise, in Maryland, a state that has sometimes followed the landowner-use rule, the court of appeals held in American Tel \& Tel. Co. v. Smith 18 A. 910 (Md. 1889), that the construction of a telephone line used solely for commercial purposes along a railroad right-of-way is an additional burden for which the servient fee owners must be compensated. The court stated:

[W] entertain no doubt whatever as to the right of a railroad company to construct on and over its right of way a telegraph or telephone line, for its use in the operation of its road and dispatch of its business; . . . But, on the other hand, if this is not the motive for its construction, and the main object in constructing it is to establish an extensive line of telegraph and telephone communication through this and other states, for general commercial purposes, for the use and benefit of the defendant, and such a line is not reasonably necessary for the purposes of the railroad, then it will be a new easement, and put a new and additional burden upon the land, for which the owners are entitled to compensation.

Id. at 913 . 
purely commercial with no railroad use. ${ }^{301}$

Where the telephone or telegraph line is used for "mixed purposes" (that is, both railroad and commercial/non-railroad uses), most states hold that no additional servitude is created. ${ }^{302}$ However, when a line in the railroad easement is used solely for commercial/non-railroad purposes, whether by the railroad itself or a third party lessee, an additional burden or servitude may be created in those landowner-use states for which the servient fee owner is entitled to compensation. ${ }^{303}$

In contrast to the telephone and telegraph line cases, the courts do not analyze the type of service offered by an electric company in disputes over electric lines in rail corridors. This approach makes little sense; electricity is just as necessary to operating a railroad as communication services. Yet the courts simply assert that either electric lines constitute an additional burden ${ }^{304}$ or they do not. ${ }^{305}$ The distinction cannot be explained by assuming that electric utilities constitute a special class because courts analyzing analogous street easements do make fine distinctions about electric use ${ }^{306}$ It is true that electric lines

301. See supra note 292.

302. See Mississippi Inv., Inc. v. New Orleans \& N.E.R. Co., 188 F.2d 245 (5th Cir. 1951); Mitchell v. Illinois Cent. R.R. Co., 51 N.E.2d 271 (Ill. 1943); Dickman v. Madison County Light \& Power Co., 136 N.E. 790 (Ill. 1922); Southwestern Bell Tel. Co. v. Bigler, 563 S.W.2d 851 (Tex. Civ. App. 1978).

303. See generally Western Union Tel. Co. v. Rich, 19 Kan. 517 (1878); Canadian Pacific Ry. Co. v. Moosehead Tel. Co., 76 A. 885 (Me. 1910): American Tel. \& Tel. Co. v. Smith, 18 A. 910,913 (Md. App. 1889); St. Louis, Iron Mountain \& S. Ry. Co. v. Cape Girardeau Bell Tel. Co., 114 S.W. 586 (Mo. Ct. App. 1908); Nicoll v. New York \& N.J. Tel. Co., 42 A. 583 (N.J. 1899); Phillips v. Postal Tel. Cable Co., 41 S.E. 1022 (N.C. 1902), rev'd on other grounds, 42 S.E. 587 (N.C. 1902); Hodges v. Western Union Tel. Co., 45 S.E. 572 (N.C. 1903); Teeter v. Postal Tel. Co., 90 S.E. 941 (N.C. 1916); Query v. Postal Tel.-Cable Co., 101 S.E. 390 (N.C. 1919); Right and Measure of Compensation, supra note 286; see also NiCHOLs', supra note 11, \$\$ 3:11.01[2][e], $5: 16.07[4]$ (discussing right of utilities in rail corridors).

304. See Tompkins v. Atlantic Coast Line R.R. Co., 79 S.E.2d 41, 47 (Ga. Ct. App. 1953); Muncie Elec. Light Co. v. Joliff, 109 N.E. 433 (Ind. Ct. App. 1915).

305. See State Highway Comm'n v. Union Elec. Co., 148 S.W.2d 503 (Mo. 1941).

306. In the situation of utility lines in streets and highways, the courts engage in lengthy discussions of whether or not electric lines have a mixed use-lighting the streets as well as providing commercial services- which they do not do for telephone or telegraph lines in streets. The cases are exactly reversed. In railroad corridors, there is lengthy analysis over telephone line use and not over electric use; in streets there is lengthy analysis over electric line use and not over telephone line use. But in both cases, the majority of courts view utility use, even when there is no street or railroad use. to be within the scope of the easement. A 1958 A.L.R. article concluded that courts in eleven states (Alabama, Indiana, Kansas, Kentucky, Massachusetts, New Mexico, Oklahoma, South Carolina, Utah, Washington, and West Virginia) and the federal courts have adopted the general rule that electric lines fall within the scope of street or highway easements because the transmission of electricity is not fundamentally different from travel on public highways. See R.D. Hursh, Electric Light 
arrived relatively late; but while electric companies received the power of eminent domain, their activities did not come with the same type of legislative imprimatur conferred on the telegraph companies.

The utility line cases are therefore a mixed bag. The federal courts and a majority of states have adopted a rule consistent with the railroad's exclusivity rights - the railroad easement is recognized as a valuable property right, nearly a fee, and carries with it the valuable right to license access to others. The railroad's power over the easement land is deemed extensive enough for it to allow any use not inconsistent with railroad use. The courts that focus on types of uses by telegraph or telephone companies, on the other hand, limit utility uses to those necessary to the railroad use. If the telegraph use is partly for the railroad with incidental commercial use, it clearly falls within the scope of the easement, but where the use is unrelated to the railroad's operations, except to bring in revenues, then a minority of states will find that it falls outside the scope of the easement. This distinction ignores the exclusivity of the railroad's easement and was followed only in landowner-use states despite the fact that the landowner could not authorize the utility use on her own without infringing on the railroad's rights to control the surface of the easement. ${ }^{307}$ This approach dramatically increases transaction costs for utilities, as utilities are forced to negotiate with, and compensate, both the railroad and the owner of the servient land, neither of which would be able to authorize the utility use independently.

of Power Line in Street or Highway as Additional Servitude, 58 A.L.R.2d 525 (1958). In nine other states (California, Illinois, Iowa, Maryland, Michigan, Mississippi, New Jersey, Tennessee, and Wisconsin). electric lines are not deemed to create an additional servitude where the lines have some direct relationship to the use of the street, as for lighting the street or operating electric street railways. See id. Ohio and Montana find no additional servitude from electric lines located in urban areas when the use of the lines is directly related to use of the street. See id. Only five states (Georgia, Louisiana, Nebraska, North Carolina, and Texas) take the position that power lines are always additional servitudes in street and highway easements. See id. This view is also changing as more and more states face challenges by landowners regarding additional utility servitudes along already burdened rights-of-way and recent cases show they too are adopting the majority view that public thoroughfares are reasonably subject to a variety of necessary public uses, from transmission of electricity and intelligence to transportation of people and cargo. A cursory review of cases since 1956 reveal that even more states are adopting the majority view that power lines do not create additional servitudes. Utah. Arkansas, Pennsylvania, Delaware, New Hampshire, and Idaho appear to have adopted the majority view that utility lines are not additional servitudes.

307. With the demise of the landowner use rule, however, this distinction should also fall into desuetude. 


\section{Incidental Use Doctrine}

The primary justification for allowing railroads to utilize unused portions of their easements for generating revenue has come to be called the "incidental use doctrine." ${ }^{308}$ This doctrine states that a railroad may use its easement to conduct not only railroad-related activities, but also any other incidental activities that are not inconsistent and do not interfere with the operation of the railroad. This means that where a railroad leases part of the corridor to a third party for a warehouse, grain silo, retail gas station, or utility corridor for commercial, non-railroad purposes, that lease should impose no additional servitude on the servient estate for which compensation might be sought.

The incidental use doctrine first arose in the 1875 U.S. Supreme Court decision in Grand Trunk Railroad Co. $v$. Richardson, ${ }^{309}$ in which the Court held that non-railroad structures could be located on a railroad right-of-way:

It must be admitted that a railroad company has the exclusive control of all the land within the lines of its roadway, ... . we are not prepared to assert that it may not license the erection of buildings for its convenience, even though they may be also for the convenience of others. It is not doubted that the defendant might have erected similar structures on the ground on which the plaintiff's buildings were placed, if in its judgment the structures were convenient for the receipt and delivery of freight on its road. Such erections would not have been inconsistent with the purposes for which its charter was granted. And, if the [railroad] company might have put up the buildings why might it not license others to do the same thing. . : .

The doctrine was applied to federally-granted rights-of-way in United States $v$. Union Pacific Railroad ${ }^{311}$ in 1957 and has been cited innumerable times in state cases since. For example, in Mitchell $v$. Illinois Central Railroad Co., ${ }^{312}$ the Supreme Court of Illinois held that no additional servitude was created where a railroad leased land to a gas station which sold gas at retail and shipped gas in bulk using the railroad. ${ }^{313}$ The majority of courts

308. See, e.g., ElLIOTT, supra note 106. § 938.

309. 91 U.S. 454 (1875).

310. Id. at 468-69.

311. 353 U.S. $112(1957)$.

312. 51 N.E.2d 271 (Ill. 1943).

313. See id. at 274 ("No compelling reason is advanced by plaintiff, or in the authorities cited by him, satisfactorily explaining why, if a bulk, or wholesale, station is allowed to be operated on a railroad right of way, the owner of the bulk station, in addition to selling wholesale, cannot likewise properly include facilities for selling at 
have allowed railroads to lease unused land for warehouses, ${ }^{314}$ billboards, ${ }^{315}$ lumberyards, ${ }^{316}$ and livestock facilities. ${ }^{317}$ They have also used the incidental use doctrine to validate leases for telegraph, telephone, electric lines, and even trails. ${ }^{318}$ Ironically, even the few states that followed the landowner-use rule and construed railroad easements narrowly against the railroads have generally allowed railroads to lease land for warehouses. ${ }^{319}$ But a few uses have been held to go beyond the permissible incidental ones. Retail gas stations with no connection to the railroad have been held to be additional servitudes, ${ }^{320}$ as have a private gin, ${ }^{321}$ a tobacco warehouse, ${ }^{322}$ and a second, unrelated railroad. ${ }^{323}$

The incidental use doctrine is the most expansive formulation of a railroad's property right and is consistent with the exclusive nature of the railroad easement. The test for allowing an additional use is that the use be "not inconsistent" with the railroad's use. ${ }^{324}$ Because the easement is so exclusive as to be nearly equivalent to the fee, the railroad is clearly within its rights to lease land for its necessary operations, such as facilities that provide coal, gas, oil, water, or electricity to run its trains. ${ }^{325}$ For example, the railroad can license McDonalds to

retail.").

314. See, e.g., Mississippi Inv. Inc. v. New Orleans \& N.E. R.R. Co., 188 F.2d 245 (5th Cir. 1951); Kansas City S. Ry. Co. v. Marrieta Oil Corp., 22 F. Supp. 279 (W.D. La. 1937); Oregon Short Line R.R. Co. v. Ada County, 18 F. Supp. 842 (D. Idaho 1937): Louisville \& N.R. Co. v. Maxey, 77 S.E. 801 (Ga. 1913); Coit v. OwenbyWafford Co., 81 S.E. 1067 (N.C. 1914); Turner v. Texas \& New Orleans Ry. Co., 59 S.W.2d 239 (Tex. Cir. Ct. App. 1933).

315. See, e.g., Bozarth, McCord \& McCrary v. Oklahoma Dep't of Transp., 812 P.2d 815 (Okla. Ct. App. 1991).

316. See, e.g., Johnson v. Union Pac. R.R. Co., 274 N.W. 581 (Neb. 1937).

317. See, e.g., Hastings v. Chicago, Rock Island \& Pac. Ry. Co., 126 N.W. 786 (Iowa 1910).

318. See, e.g.. City of Sioux City v. Missouri Valley Pipe Line Co., 46 F.2d 819, 826 (N.D. Iowa 1931); Bumier v. Department of Envtl. Resources, 611 A.2d 1366 (Pa. Commw. Ct. 1992); Fort Worth \& Rio Grande Ry. Co. v. Southwestern Tel. \& Tel. Co., 7 IS.W. 270 (Tex. 1903).

319. See, e.g., Sparrow v. Dixie Leaf Tobacco Co., 61 S.E.2d 700 (N.C. 1950); Shelton v. Southern Cotton Oil Co., 90 S.E. 751 (S.C. 1916); City of Knoxville v. Kaiser, 33 S.W.2d 411 (Tenn. 1930).

320. See In re Chicago \& N.W. Ry. Co., 127 F.2d 1001 (7th Cir. 1942); Mitchell, 51 N.E.2d 271 (Ill. 1943).

321. See Bond v. Texas \& Pac. Ry. Co., 160 So. 406 (La. 1935).

322. See Dixie Leaf Tobacco, 61 S.E.2d at 700.

323. See Blakely v. Chicago. Kan. \& Neb. Ry. Co., 51 N.W. 767 (Neb. 1892).

324. See, e.g., City of Knoxville v. Kaiser, 33 S.W.2d. 411 (Tenn. 1930).

325. See, e.g. State Hwy. Comm'n v. Union Elec., 148 S.W.2d 503 (Mo. 1941) (electric lines); Mize v. Rocky Mountain Bell Tel. Co., 100 P. 971 (Mont. 1909) (ditches); Luedeke v. Chicago \& N.W. Ry. Co., 231 N.W. 695 (Neb. 1930) (gasoline); 
operate a restaurant for passengers in its depot. ${ }^{326}$ It can lease land for construction of livestock pens, ${ }^{327}$ gins for grain, ${ }^{328}$ or cranes for heavy freight. ${ }^{329}$ In the process, the owners of these facilities, who use the railroad for their business, may also sell commercially to the non-railroad public, as when nearby workers go to McDonalds for lunch. ${ }^{330}$

The justification for allowing these incidental uses is threefold: (1) the use is nominal compared to the already burdensome railroad use; (2) the easement gives the railroad exclusive use rights to the land, so no one else could authorize the third party uses; and (3) the use is a railroad use insofar as it relates in some way to the railroad's business. Because railroad easements are so large and burdensome, any incidental uses are usually so minimal compared to the primary rail use that damages would be nominal.

The rule requires that the use must be "incidental," not completely unrelated to rail use. Hence, warehouses that provided storage for the railroads' shippers or telegraph lines that provided communication for the railroad clearly met the requirements of the incidental use doctrine. ${ }^{331}$ The courts disagree, however, over whether a lease to a third-party user that merely generates income for the railroad's general operating budget, without some non-economic connection, meets the requirement. An Oklahoma appeals court, for example, upheld a billboard lease in a railroad easement, simply restating the general rule that "[a] railroad company may lease its property which is not required for railroad operations to other parties for commercial use." ${ }^{332}$ But a telegraph line unconnected to the railroad was held to be an additional servitude in Tennessee. ${ }^{333} \mathrm{~A}$ North Carolina court even explained how to draw that fine line

Fort Worth \& Rio Grande Ry. Co. v. Southwestern Tel. \& Tel. Co., 71 S.W. 270 (Tex. 1903) (telegraph lines).

326. See, e.g.. Cleveland, Cincinnati, Chicago \& St. Louis Ry. Co. v. Mitchell, 74 Ill. App. 602 (IIl. App. Ct. 1897); John Hamilton v. Annapolis \& Elk Ridge R.R. Co., 1 Md. 553 (Md. Ct. Spec. App. 1852).

327. See Coit v. Owenby-Wofford Co., 81 S.E. 1067 (N.C. 1914).

328. See Mitchell v. Illinois Cent. R.R. Co., 51 N.E.2d 271 (Ill. 1943).

329. See Robertson Coal \& Coke Co. v. Rothey, 162 A. 332 (Pa. Super. Ct. 1932).

330. See Mitchell, 51 N.E.2d at 274 ("No compelling reason . . why, if a bulk, or wholesale, station is allowed to be operated on a railroad right of way, the owner of the bulk station . . . cannot likewise ... sell[l at retail.").

331. See Mellon v. Southern Pac. Transp. Co., 750 F. Supp. 226 (W.D. Tex. 1990).

332. Bozarth, McCord \& McCrary, v. Oklahoma Dep't of Transp., 812 P.2d 815. 816 (Okla. Ct. App. 1991).

333. See Western Union Tel. Co. v. Nashville, Chattanooga \& St. Louis Ry. Co., 237 S.W. 64, 65 (Tenn. 1922). 
between primary railroad use and incidental commercial use in terms reminiscent of the distinction between public and private owners in the "public use" prong of takings jurisprudence. ${ }^{334}$ That court stated:

When the use by third parties is primarily for the benefit of the railroad as a common carrier, then it is for railroad purposes even though incidental benefits flow to the private user. On the other hand, if the use is primarily private in nature, the fact that the railroad is incidentally benefited thereby, through the acquisition of a new customer or increased shipments, does not convert it into a railroad use. ${ }^{335}$

Despite the line-drawing problem, the modern trend arguably focuses less on the relationship between the railroad use and the third-party use, and instead validates any uses that are "not inconsistent" with railroad use. ${ }^{336}$

To avoid the primary/incidental use distinction, a few courts look instead to the original intention of the parties, though these intentions usually were not made very clear in the original instruments. ${ }^{337}$ Where the servient landowner retains access rights to drill for minerals, for instance, the railroad clearly could not authorize its own lessee to do so. ${ }^{338}$ Or, where the landowner specifically included a provision for permitting his hotel to remain on the burdened land, he was permitted to maintain the yard, fence a garden, and plant trees on the railroad's easement. ${ }^{339}$ In other words, some grantors have explicitly reserved rights that would otherwise fall under the incidental use rights of the railroad. Perhaps the best rule is that all incidental uses are permissible unless explicitly retained by the grantor.

Making it the presumption that all use rights are conveyed

334. See Sparrow v. Dixie Leaf Tobacco Co., 61 S.E.2d 700 (N.C. 1950); see also Poletown Neighborhood Council v. City of Detroit, 304 N.W.2d 455, 458 (Mich. 1981) ("[C]ondemnation for a private use cannot be authorized whatever its incidental public benefit and condemnation for a public purpose cannot be forbidden whatever the incidental private gain.").

335. Sparrow, 61 S.E.2d at 703-04.

336. Mellon v. Southern Pac. Transport. Co., 750 F. Supp. 226 (W.D. Tex. 1990); Garry v. Atchison, Topeka \& Santa Fe Ry. Co., 378 P.2d 609 (N.M. 1963). This is about as helpful a line to draw as Justice Holmes' enigmatic regulatory takings line, that interference with property constitutes a taking when it "goes too far." Pennsylvania Coal Co. v. Mahon, 260 U.S. 393 (1922).

337. See, e.g., Garry v. Atchison, Topeka \& Santa Fe Ry. Co., 378 P.2d 609 (N.M. 1963).

338. See Missouri-Kan.-Tex. R.R. Co. v. Freer, 321 S.W.2d 731, 737 (Mo. Ct. App. 1958).

339. See Mobile \& Ohio R.R. Co. v. Donovan, 58 S.W. 309, 313 (Tenn. 1900). 
unless specifically excepted would certainly reduce litigation. As one commentator explained:

Landowners usually contest divisibility of easements to gain the economic advantage of making the transfer to the second easement holder, rather than allowing the first grantee to reap the economic benefit of a division. Courts have not been sympathetic to the landowner's position and ... uniformly have supported the first grantee's right to divide his easement. ${ }^{340}$

Because the intent of the original grantor as to the scope of the easement is the critical issue, courts will generally allow incidental uses to which the servient landowner consented over an extended period of time. The landowner's failure to complain about a single third-party use may give rise to a presumption that the intent of the parties was to allow any additional thirdparty incidental uses. ${ }^{341}$ Original intent, therefore, can be gleaned from the ongoing actions of the parties and, when coupled with the incidental use doctrine, can play an important role in assessing the divisibility of a railroad easement. ${ }^{342}$

While some courts retain the distinction between railroad use and purely commercial use, even though it is often unworkable, the more effective approach is to allow all thirdparty uses that are not inconsistent with railroad use on the ground that the railroad knows best what it can and cannot allow on the easement consistent with its public carrier duties. For example, general revenues from third-party uses are important to the railroad's operations even without noneconomic benefits to the railroad. In addition, the public nature of the railroad easement would support a broad rule on divisibility because, as one court noted that "an easement acquired by the public includes every reasonable means for the transmission of intelligence, the conveyance of persons, and the transportation of commodities which the advance of civilization may render suitable for a highway." 343

340. Hegi, supra note 44, at 133.

341. See Cincinnati, New Orleans \& Tex. Pac. Ry. Co. v. Barker, 247 S.W.2d 943, 946 (Ky, 1952).

342. As one commentator explained: "landowners usually contest divisibility of easements to gain the economic advantage of making the transfer to the second easement holder, rather than allowing the first grantee to reap the economic benefit of a division. Courts have not been sympathetic to the landowners' position and ... uniformly have supported the first grantee's right to divide his easement." Hegi, supra note 44 , at 133 .

343. Kentucky \& West Va. Power Co. v. Crawford, 16 S.W.2d 1041 (1929). 


\section{Modern Fiber Optics and the Current Class Action Suits}

Modern disputes between landowners and railroads seem to lie in the divisibility of railroad easements for the laying of fiberoptic cables. Fiber-optic cables are the wave of the future; they are the information superhighway of the twenty-first century. ${ }^{344}$ Straight, level-grade railroad corridors and high-voltage power lines are the preferred locations for fiber-optic cables as they may run for hundreds of miles without interruption. But as with the telegraph, and then the telephone, fiber optics are being challenged in the courts as constituting an additional servitude on railroad easements. ${ }^{345}$

The states are in disagreement as to whether fiber-optic lines on a railroad easement constitute an additional servitude. Under the theory of the telegraph cases, fiber-optic uses that devote a portion to railroad services (for example, where the railroad leases space to a fiber-optic company in exchange for a percentage of bandwidths on the cable or a preferential rate for railroad uses) should not constitute an additional burden on the servient estate. Under the incidental use doctrine, even pure commercial/non-railroad fiber-optic uses should not constitute an additional burden. But of the three cases directly addressing fiber optics, only two followed the majority rule, while the third, a Tennessee case, followed the minority rule. ${ }^{346}$

344. See Wilner, supra note 5 , at 278 (defining fiber optics as "the pulsing of light by laser through a dark cable that can carry thousands of digitized voice circuits. The cable must not break (as light would enter) and it must not be bent (as the light signal would be compromised). If the cable must be buried, it must be buried beneath the frost line so that the freeze-thaw cycle does not create kinks in the line that affect the light signal.").

345. See, e.g., Davis v. MCI Telecomm. Corp., 606 So. $2 d 734$ (Fla. Dist. Ct. App. 1992); Calumet Nat'l Bank v. American Tel. \& Tel. Co., 682 N.E.2d 785 (Ind. 1997); CSX Transp., Inc. v. Clark, 646 N.E.2d 1003 (Ind. Ct. App. 1995); Meighan v. United States Sprint Comm. Co., 942 S.W.2d 476 (Tenn. 1997); Buhl v. United States Sprint Comm. Co.. 840 S.W.2d 904 (Tenn. 1992); Mellon v. Southern Pac. Transp. Co., 750 F. Supp. 226 (W.D. Tex. 1990).

Ironically, one of the first companies to get into laying fiber-optic cable was Southern Pacific Transportation (of railroad fame), which created Sprint Communications and laid hundreds of miles of fiber-optic cables in their own railroad corridors. The other big players, AT\&T and $\mathrm{MCI}$, found rail corridors to be ideal locations for leasing fiber-optic space. MCI purchased the rights-of-way of the former Western Union Telegraph Company to bury its cables. See Wilner, supra note 5, at 274-76. Interesting questions arise as to whether the railroad can install these lines if they own the company laying them. Would doing so violate the "railroad use" restriction?

346. A recent decision out of the District Court for the Northem District of Oklahoma, Hallaba $v$. Worldcom Network Services, Inc., No. 98-CV-895H lorder entered Mar. 31,2000), denied a motion for class certification of adjacent landowners against a fiber-optic company, on the ground that there are too many fact and law 
In Mellon v. Southern Pacific Transport Co., the Federal District Court for the Western District of Texas, on a summary judgment motion, held that under Texas law no compensation was due to the servient fee owners of an estate burdened by a railroad easement when the railroad company, Southern Pacific Transportation, leased a portion of the railroad easement for the placement of a buried fiber-optic cable. ${ }^{347}$ The fiber-optic line was used primarily for commercial, non-railroad purposes and partly for railroad purposes. The Mellon court did not cite this mixed use as a factor in its determination. ${ }^{348}$ Rather, the court relied heavily on the incidental use doctrine which "allows railroads to contract with third parties and controls the permissible scope of railroad authorized right-of-way uses and allows third party commercial uses of the railroad right of way." ${ }^{349}$ The court found the incidental use doctrine adequate to deny compensation to the servient estate owner, even though the use was mixed. ${ }^{350}$ The court also cited other courts that had applied the incidental use doctrine to other kinds of uses, and it noted that the right-of-way included the non-mineral subsurface of the easement. ${ }^{351}$ It is not clear, however, whether the same result would obtain were the fiber-optic line to be used solely for commercial, non-railroad purposes.

In the second case, Davis v. MCI Telecommunications Corp., a Florida District Court of Appeals reached the same result as the Mellon court using a different theory. ${ }^{352}$ The court upheld a lower court's ruling that the servient fee owners of a railroad easement were not entitled to compensation where MCI, pursuant to an eminent domain statute, buried a fiber-optic cable in the railroad

differences to meet the commonality requirement.

347. See 750 F. Supp. 226 (W.D. Tex. 1990).

348. See id. at 231 ("This court finds the right-of-way surface includes the nonmineral topsoil that would be occupled by a buried fiber optic line, and the fiber optic cable is an authorized incidental use which is not inconsistent with railroad uses and does not burden the subservient estate retained by the Plaintiff. Plaintiff has not demonstrated under the terms of the easement or under controlling law it has retained an interest in the rallroad's easement for which it should receive rents, the Court finds Plaintiff's arguments unpersuasive.").

349. Id. at 229 (citing Grand Trunk R.R. v. Richardson. 91 U.S. 454, 468-69 (1895)).

350. See id. at 229-30.

351. See id. at 230 (citing Fort Worth \& Rio Grande Ry. Co. v. Southwestern Tel. \& Tel. Co., 71 S.W. 270 (Tex. 1903); Citizens Telephone Co. v. Cincinnati, New Orleans \& T.P. R. Co., 233 S.W. 901, 903 (1921)); see also Bozarth, McCord, and McCrary v. Oklahoma Dep't of Trans., 812 P.2d 815 (Okla. Ct. App. 1991) (citing McCurley v. City of El Reno, 280 P. 467 (Okla. 1929)) (allowing incidental uses but not mentioned by the court in Mellon).

352. 606 So. 2d 734 (Fla. Dist. Ct. App. 1992). 
easement which ran over the Davis' property. MCl's buried fiberoptic cable was used primarily for commercial, non-railroad purposes and partly for the railroad's own communication needs. But, just as in Mellon, the court did not rely on the mixed use of the fiber-optic cable when it concluded that the landowner was not entitled to compensation. Instead, the court in Davis reasoned that telegraph and telephone uses, and by analogy fiber-optic uses, were permitted by virtue of a state statute permitting telegraph companies to lay their lines in the right-ofway of any railroad in the state and that the fiber-optic use was even less burdensome than the telegraph use. ${ }^{353}$ The Davis court also explicitly rejected the incidental use doctrine, but it remains open whether a Florida court would apply it in a case where a statutory justification was not available for authorizing the cable use.

Fiber-optic companies have not been successful in all states. The Tennessee Supreme Court in Buhl $v$. United States Sprint Communications Co. held that the installation of a fiber-optic cable in a railroad easement constituted a taking of the servient fee owner's property. ${ }^{354}$ The dispositive issue for this court was that the buried fiber-optic line was used solely for commercial, non-railroad uses. ${ }^{355}$ The court stated that, under Tennessee precedents, the appurtenance must be related to a railroad purpose, or else a taking would occur. ${ }^{356}$

The history of the Buhl case, however, is problematic. At trial, the court granted summary judgment for the railroad and Sprint Communications, finding the license within the scope of the railroad easement. ${ }^{357}$ The Tennessee Court of Appeals, in a

353. See id. ("Unlike the many wire lines on Western Union's telegraph poles, MCI's fiber optic telecommunications cable is less than one inch in diameter, is buried approximately three feet deep, and is used for telephone and other telecommunication purposes, both by the railroad for its own communications needs and by customers of MCI for communications purposes. Certainly, the MCI cable imposes no greater obstruction along the railroad than the former Western Union lines.").

354. 840 S.W.2d 904 (Tenn. 1992).

355. See id. at 911 ("The conclusion is that since the telephone cable installed by Sprint is not used by Southern [the railroad company in question] in the construction. maintenance. or operation of its railroad upon and across the encumbered property, its construction constituted the taking of an interest in plaintiffs respective tracts within the meaning of the law of eminent domain.").

356. See id. ("The critical requirement is that the appurtenances be used in connection with the operation of the railroad upon and across the encumbered property.").

357. See Kristi Robbins Rezabek, Property Law-Buhl v. U.S. Sprint Communications Co.: Ascertaining the Rights of Fee Owners on Whose Land a Railroad Easement Exists, 22 MEMPHIS ST. U. L. REV. 843 (1992). 
moment of strange incoherence, found that the license was within the scope of the railroad's easement but that the landowners were also entitled to compensation. ${ }^{358}$ The Tennessee Supreme Court was at least consistent in finding that the license was outside the scope of the easement and therefore that compensation must be paid, but this conclusion was at odds with prior Tennessee case law adopting the incidental use doctrine, ${ }^{359}$ finding that a telephone line in a railroad easement was a "proper railroad appurtenance," ${ }^{360}$ and finding that telecommunication lines in a street did not impose an additional servitude. ${ }^{361}$

Although Tennessee is one of the landowner-use states, it has held that telegraph use is consistent with railroad use and is not an additional burden. ${ }^{362}$ Moreover, the Buhl decision is inconsistent with the wide-spread statutory schemes of most states to encourage location of utilities and cable television wires along public highways, pre-existing utility corridors, and railroad easements where they are least burdensome and most efficient. ${ }^{363}$ And not surprisingly, Tennessee's openness to these suits has led to a series of cases filed by landowners that have yet to be resolved. ${ }^{364}$

Harmonizing Mellon, Davis, and Buhl is not possible. In both Mellon and Davis, the fiber-optic line was a mixed railroad/commercial line, but neither court cited that fact as a reason for holding that no compensation was due to the servient owner. The Mellon court held that no compensation was due because the placement of a fiber-optic line in the easement was an incidental use within the scope of the railroad's easement. The Davis court, on the other hand, held that the placement of the fiber-optic line was not compensable because it was authorized by statute and constituted only a nominal burden. In Buhl, the fiber-optic line was strictly commercial, and that became the dispositive issue for the court. Mellon, Davis, and $B u h l$ thus are instructive to courts facing the issue of whether a buried fiber-optic cable in a railroad easement constitutes an

358. See Buhl v. United States Sprint Comm. Co., 1991 WL 16250 (Tenn. Ct. App. 19911.

359. See City of Knoxville v. Kaiser, 33 S.W.2d 411 (Tenn. 1930).

360. See Mobile \& Ohio R.R. v. Postal Tel. Cable Co., 46 S.W. 571 (Tenn. 1898).

361. See Frazier v. East Tenn. Tel. Co., 90 S.W. 620 (Tenn. 1906).

362. See Mobile, 46 S.W. 571.

363. See generally Rezabek, supra note 357.

364. See, e.g., Meighan v. United States Sprint Comm. Co., 942 S.W.2d 476 (Tenn. 1997): McCumber v. United States Sprint Comm. Co., No. 23,796-III (Cocke Co. Cir. Ct. filed June 6, 1996). 
additional, compensable burden on the servient estate, but they by no means detail a comprehensive rule that would be generalizable over a majority of states.

The three fiber-optic cases are particularly unhelpful to the current spate of class action suits for a number of reasons. First, nuances and differences in the incidental use doctrine in each state preclude application of a uniform rule to corridors in all fifty states. Second, the type of use, whether mixed or purely commercial, will call forth different state rules on divisibility. Third, the sheer number and variety of plaintiffs in these class actions mean that the courts must conduct numerous title determinations to decide which parcels were granted to the railroads in fee simple and which as easements, determinations best left to the quiet title mechanisms already in place in each state to make exactly these determinations. ${ }^{365}$ Furthermore, there is little to be gained for landowners in these disputes because, even if the fiber optics are held to be an additional use, the servient fee owner will be compensated only for the difference in value of the fee before and after construction of the utility lines. ${ }^{366}$

Finally, these three fiber-optics cases raise the additional question of what happens to utility licenses when the railroad abandons its rail service. This question includes a multitude of disparate issues about which corridors were abandoned pursuant to state law, which cables were located prior to abandonment and which post-abandonment, and which corridors were protected under federal railbanking. These issues need resolution so that necessary public services can be provided without leaving landowners, the railroads, or the utility companies in limbo for the years it may take these cases to work

365. This issue is particularly divisive in Indiana. See generally WRIGHT, supra note 133; Wright, supra note 160 (explaining how the law on railroad title makes for contentious litigation). The issue is divisive in other states as well. See, e.g., Hallaba v. Worldcom Network Service. Inc., No. 98-CV-895-H (N.D. Okla Mar. 31. 2000).

366. See Right and Measure of Compensation, supra note 286, at n.97; see also Nichols', supra note 11, 88 3:11.01[2][e], 5:16.07[4]; Chicago, M. \& St. P. Ry. Co. v. Snyder, 95 N.W. 183 (Iowa 1903); Teeter v. Postal Tel. Co., 90 S.E. 941 (N.C. 1916); Hodges v. Western Union Tel. Co., 45 S.E. 572 (N.C. 1903).

The fee owner is not entitled to an accounting of the profits received from a telephone company to a railroad company concerning the utility lines in the railroad easement. See Snyder, 95 N.W. at 183. In one case, the servient landowner was denied all recovery, even though the telegraph company had wrongfully trespassed by putting three poles on her land, outside the railroad easement, on the grounds that the damages were only nominal and the telegraph company was in the process of relocating the poles back to the railroad easement. See Campbell v. Southwestern Tel. \& Tel. Co., 158 S.W. 1085, 1086 (Ark. 1913). 
through the courts. At this point, however, the fiber-optics cases follow the majority incidental use rule, an approach we support.

\section{Using the Telephone Cases as Precedent}

Although at first blush it appears that fiber-optic lines could be handled in much the same fashion as telephone lines, which distinguish between commercial and railroad use, a buried fiberoptic line is quite different from a telephone line. In fact, it might be more logical to treat buried fiber-optic lines like buried pipelines rather than like telephone lines strung on poles. ${ }^{367}$

The first distinction between telephone lines and poles and a buried fiber-optic line is physical size and presence. While telephone lines and poles are tall and imposing, and the lines strung on them often numerous and cluttered, buried fiber-optic lines are barely half an inch in diameter, and usually only one runs within the corridor. In terms of physical size and presence, the fiber-optic line and its appurtenant structures (repeaters) are far smaller and fewer in number than telephone lines and poles. ${ }^{368}$

Another critical distinction between telephone lines and fiber-optic lines is their location. Fiber-optic lines are buried below ground (beneath the frost line, generally around 36 inches) $^{369}$ while telephone poles and lines sit above ground. Unquestionably telephone lines and poles are more unsightly than buried fiber-optic lines. Having a buried fiber-optic line running 36 inches below the surface of the railroad easement will likely have little if any effect upon the value of the servient fee, whereas telephone lines and poles in the railroad easement might have some measurable negative effect upon the value of the fee estate. At least in the case of electric powerlines and poles, such unsightliness is often an element of damages in easement condemnation proceedings. ${ }^{370}$

The telephone line poses numerous possible burdens; it is unsightly, repair crews might need access to the lines and poles through the servient estate, and the poles and lines may pose a danger to people on the land of the servient estate (the poles may

367. Although no legal consequences per se flow from characterizing buried fiberoptic lines as "pipelines" instead of telephone lines (and poles), such characterization more accurately comports with the physical and geographical nature of the buried fiber-optic line.

368. See Wilner, supra note 5, at 273.

369. See id.

370. See generally Unsightliness of Powerline, supra note 47. 
fall and the wires may electrocute). ${ }^{371}$ In many cases, however, fiber optics are located within pre-existing gas pipelines so it can hardly be argued that they are an additional burden. ${ }^{372}$ Laying the cables might not even require digging up the surface. If the key to whether a railroad may grant a subeasement is whether that subeasement imposes an additional burden on the servient estate, then a fiber-optic cable is one of the least intrusive thirdparty uses the railroads have authorized to date.

\section{E. The Scope of the Railroad Easement-Revisited}

The scope of the railroad easement is quite extensive. All states recognize that it is exclusive as against the servient landowner. ${ }^{373}$ Even the four states that adopted the landowneruse rule draw very narrow lines for the servient owner. ${ }^{374}$ States do, however, differ in their approach to the scope of the easement. Some states adopt an approach that relies heavily on the physical dimensions of the easement - the width, depth, and height of the railroad corridor itself. The majority of states, however, look to the railroad use and the intention of the original parties to the grant to determine whether the railroad may grant third-party licenses to use either the airspace or the sub-surface estate for utilities. Some of the states within this majority will limit third-party uses to ones having some relationship to railroad operations, a relationship other than mere economics. The federal courts and most states, however, adopt a fairly liberal incidental use doctrine that gives railroads significant power to grant third-party uses within the easement so long as the uses are not inconsistent or do not interfere with the railroad's common carrier duties.

Telegraph and telephone uses have caused a significant

371. See Selective Resources v. Superior Court, 700 P.2d 849, 851 (Ariz. Ct. App. 1984) (alleging potential harm from electromagnetic fields associated with the lines).

372. See Wilner, supra note 5, at 275 . See generally Worldcom Network Services, Inc. v. Thompson, 684 N.E.2d 211 (Ind. Ct. App. 1997); Kim Hooper, Cable Cutting Violated Order, Court Rules, INDIANAPOLIS STAR, Aug, 20, 1997; Kim Hooper, Landowners Can't Touch WorldCom Cable . ... INDIANAPOLIS STAR, June 20, 1997, for details on a dispute that led to a landowner digging up a WorldCom fiber-optic cable and cutting it even though the cable had been located in an abandoned gas pipeline.

373. See infra. Part III.B (discussing exclusivity).

374. A servient owner may only use the easement for agricultural uses and may not erect permanent structures. A servient owner may be given some slight control over private grade crossings but if the railroad chooses to relocate them, the owner has no say, and unless the owner reserved a right to enter the easement, only a waiver will justify the owner's limited entry onto the easement. See infra Part III.B (discussing exclusivity). 
amount of litigation, but a majority of courts continue to recognize the close interrelationship between the railroads and communications companies. Because the railroads require the ability to communicate between stations, they have often been active partners in providing communications services. Thus, especially under statutory grants favoring telegraph development, the distinction between utilities that provide services to the railroads and those that are purely commercial makes little sense, which may explain why telegraph and telephone use is generally found to be within the scope of the railroad easement.

In certain ways, the telegraph and telephone cases provide logical precedents for the modern-day equivalent: the fiber-optic line. But fiber optics are also substantially different in that they impose a far lighter burden on the servient owner than telephone poles and lines. Consequently, the split among the courts with regard to fiber-optic lines raises some profound questions for states that have not addressed the issue. Since there were over 10 million miles of fiber-optic lines deployed by $1995,{ }^{375}$ and that number continues to grow, virtually every state must decide this issue for itself. This Article attempts to provide some history for the practice of third-party uses in rail corridors and a theory for reconciling these disparate cases into a single, permissive doctrine. We suggest that courts adopt a position that protects fiber-optic lines in railroad corridors from claims by servient landowners on the ground that rail corridors, like streets and highways, are valuable public transportation corridors in which the public has a vested right. So long as the rail corridor is meeting the public needs of its common carrier status, the minimal burden of a buried fiber-optic line is certainly consistent with prior case law and statutes.

Unfortunately, we cannot end here, for railroads are abandoning their lines at an unprecedented rate. In the 1920s the nation had over 270,000 miles of rail corridor. By the early 1990 s only half that mileage remained. ${ }^{376}$ What happens, therefore, to telephone lines, electric lines, and fiber-optic cables that were located in a functioning rail corridor when the railroad picks up its tracks and ties and abandons its property interests? That is the subject of the next Part.

375. See Wilner, supra note 5, at 276.

376. See Charles Montange, Preserving abandoned RaIlRoad RightS-OF-Ways FOR PUblic USE: A Legal Manual For tHe RaILS to TRAILS CONSERVANCY 1 (1989); Steven R. Wild, A History of Railroad Abandonments, 23 TRANSP. L.J. 1 (1995). 
IV

ABANDONMENT

Because railroads are abandoning their corridors at unprecedented rates and internet connections, cable television, and multiple phone lines are becoming increasingly common in the average household, it is important to reconcile the property rights of utility companies with those of railroads, abutting landowners, and the general public. We address in this Part, first, the general law governing abandonment; second, the emerging shifting public use doctrine; and third, the Rails-toTrails conversion of abandoned rail corridors.

\section{A. Abandonment of a Common Law Easement}

We are first confronted with the question of how a railroad loses its easement through abandonment. Unlike fee simple title, which cannot be abandoned even by an owner who no longer wants the land, ${ }^{377}$ an easement is merely a right to use and occupy someone else's land. Because the easement owner does not have title to the land, she can relinquish her rights through release or abandonment, and the servient land becomes free and unburdened from the servitude. Railroads are commonly held to have abandoned their easements when they discontinue rail services and remove their tracks and ties. ${ }^{378}$

Determining abandonment of the property right is not that simple, however. In the first place, rail operations are governed by the federal government through the Surface Transportation Board (STB), the successor to the Interstate Commerce Commission (ICC). ${ }^{379} \mathrm{~A}$ rail carrier simply cannot discontinue services if there are shippers or passengers along a line who require rail service. ${ }^{380}$ But rail service, which is the subject of

377. Although one can abandon personal property by, for instance, placing it on the curb for the garbage collectors, one cannot abandon real property because the law requires that there be an owner of the present estate of all real property at all times. Property taxes, for instance, will be debited to the account of the owner until the land is transferred, either by deed, or by court order.

378. See Connelly, supra note $111, \$ 5$.

379. The Surface Transportation Board has taken over the duties of the Interstate Commerce Commission with respect to railroad abandonments pursuant to the ICC Termination Act of 1995, Pub. L. No. 104-88, $\$ \S 101-02,109$ Stat. 803, 804-52 (1995) (codified at 49 U.S.C. $\$ \S 10101-11908$ (1994 \& Supp. I 1995)). The ICC Act. however, does not cover all railroads, for it exempts short line and certain other carriers. See 49 U.S.C. \$ 10501 (1994).

380. Prior to abandonment, the STB must grant a certificate that the present or future public convenience and necessity permit such an abandonment. Transportation Act of Feb. 28, 1920, ch. 91, \$ 402, 41 Stat. 456, 477. 
STB jurisdiction, is not directly related to the state-law property rights that a railroad might have obtained in its land.

Prior to 1920 , a railroad that found a particular line unprofitable could not simply discontinue services and remove its tracks because many states had imposed strict limitations in their charters, had passed restrictive legislation, or had imposed contractual obligations that bound the railroads to a variety of administrative requirements before they could abandon a line. Because these laws often forced them to operate unprofitable lines and thus were affecting interstate commerce, Congress intervened in 1920 with the Transportation Act, ${ }^{381}$ effectively preempting the myriad state laws in favor of a centralized system of control over interstate shippers and carriers. Since 1920, railroads have been permitted by the ICC to abandon unprofitable lines when there was no showing of a "serious, adverse impact on rural and community development." 382 Consequently, the "impact of federal preemption has been to stultify the development of state law, leaving the case law in the position it held prior to World War I when railroads were under construction, and rail abandonments were rare birds indeed. ${ }^{\text {"383 }}$

Since 1920, therefore, when a railroad determines that a line is no longer profitable and it seeks to discontinue service along that route, it may initiate proceedings before the STB for a finding that "present or future public convenience and necessity require or permit the abandonment or discontinuance." 384 If such a finding is made, a certificate of discontinuance will issue from the STB. The railroad then has one year to complete its abandonment proceedings, which require that it notify the STB that it has fully abandoned the rail line, at which time the discontinuance certificate will become an abandonment certificate. If the railroad does not notify the STB that it has consummated abandonment procedures within the one year period, the certificate of discontinuance will expire and the line will remain on the STB's active carrier list. ${ }^{385}$

Prior to the acquisition of a discontinuance certificate from

381. See id. ("No carrier by railroad subject to this Act shall abandon all or any portion of a line of railroad, or operation thereof, unless and until there shall first have been obtained from the Commission a certificate that the present or future public convenience and necessity permit such an abandonment."].

382. 49 U.S.C. § 10903(d) (1994).

383. Montange, supra note 105 , at 160 .

384. 49 U.S.C. \& 10903 (d) (1994).

385. See generally Melons Grown in South Texas; Increased Expenses and Establishment of Assessment Rate, 61 Fed. Reg. 248 (1996). 
the STB, federal railroad regulations preempt all state laws dealing with railroads, including state property laws. Yet, some courts have improperly applied state property law before STB action, finding that the railroad had abandoned its easements under state law prior to obtaining federal abandonment authorization. ${ }^{386}$ Thus a railroad may be forced to provide services along a corridor in which its property rights were previously extinguished under state law. ${ }^{387}$ At least one state has codified the rule that abandonment of service shall not mean or imply that the easements have been abandoned. ${ }^{388}$

Once a carrier has been authorized by the STB to discontinue services and abandon a line, it may divest itself of its property rights, which is a process governed by state property law. Under state law, abandonment of a railroad easement generally requires intent to abandon and consummation of that intent through actions inconsistent with retaining the property interest. $^{389}$ Selling the corridor line is an unequivocal act of abandonment, but railroads that retain the property may be deemed to have abandoned their easements simply by virtue of their discontinuance of services, removal of tracks and ties, or nonuse. Abandonment of the property and discontinuance of services are not the same thing. ${ }^{390}$ But these two distinct stages are conflated by many courts. ${ }^{391}$ A railroad may discontinue services and then divest itself of its property, or it may discontinue services and remove tracks and ties but keep the property by continuing to pay taxes, regulating grade crossings, maintaining drainage, and generally continuing to act like an owner. ${ }^{392}$

Nonuse, by itself, is generally insufficient to constitute

386. See Kansas City Area Transp. Auth. v. 4550 Main Assoc., Inc., 742 S.W.2d 182, 191 (Mo. Ct. App. 1986) (stating that regardless of ICC action, railroad had already abandoned easement under state property law) (modified and readopted 1987). See Sennewald, supra note 147 , at 1399 , for a thorough discussion of the illogic of this decision.

387. See National Wildlife Fed'n v. I.C.C., 850 F.2d 694, 703-04 (D.C. Cir. 1988) (noting that state law cannot cause the reversion of property rights in railroad corridors prior to ICC-approved abandonment).

388. See ME. REv. Stat. AnN. tit. 23, § 7105(B) (West 1998).

389. See generally Connelly, supra note 111 .

390. See, e.g., id. $\$ 10$.

391. See id. \& 7; cf. Chevy Chase Land Co. v. United States, 733 A.2d 1055, 1086 (Md. 1999); Kansas City Area Transp. Authority v. 4550 Main Assoc. Inc., 742 S.W.2d 182 (Mo. Ct. App. 1986).

392. See Connelly, supra note 111, § 9; cf. Cary Enter. v. CSX Transp. Inc., No. 95-03311-CH (Mich. 29th Cir. Ct. Apr. 19, 1996) (order granting summary judgment for defendants). 
abandonment as nonuse is not the necessary "clear, unequivocal, and decisive act of the party showing a determination not to have the benefit intended [by the grant]." ${ }^{393}$ Failure to use all of a granted easement likewise does not constitute abandonment of the unused portion. ${ }^{394}$ Fencing a portion of a corridor and leaving unfenced an additional area has been held to indicate intent not to abandon. ${ }^{395}$ Payment of taxes has been held to indicate intent not to abandon even after over nine years of nonuse. ${ }^{396}$

Where nonuse occurs with other circumstances, abandonment may be found. Certainly where the terms of the grant require termination after a certain period of nonuse, nonuse by itself will support abandonment. ${ }^{397}$ Failure to construct the rail line once the corridor is initially obtained will usually justify a finding of abandonment. ${ }^{398}$ But in one state, even failure to construct the line for over nineteen years after condemnation of the land only raised a presumption of an intention to abandon. ${ }^{399}$ Offers for sale often are held to be evidence of intent to abandon. ${ }^{400}$ Adverse possession by another in addition to nonuse by the railroad may be sufficient to find abandonment. ${ }^{401}$ But even where the railroad only enclosed a portion of its right-of-way and an adverse user had constructed a building on the remaining portion, the court held there was no abandonment of the adversely-used land. ${ }^{402}$

Removal of tracks and ties have often been held to constitute evidence of intent to abandon because the running of trains is thereby rendered impossible. ${ }^{403}$ But there are numerous cases to

393. Townsend v. Michigan Cent. R.R. Co., 101 F. 757, 761 (6th Cir. 1900).

394. See Morgan v. Des Moines Unton Ry. Co., 85 N.W. 902, 906 (Iowa 1901).

395. See Allard Cattle Co. v. Colorado \& S. Ry. Co., 530 P.2d 503, 504 (Colo. 1974); Chicago \& S.E. Ry. Co. v. Wood, 66 N.E. 923, 923 (Ind. Ct. App. 1903).

396. See People v. Southern Pac. Co., 158 P. 177, 180 (Cal. 1916).

397. See Atlantic Coast Line R.R. Co. v. Sweat, 171 S.E. 123, 129 (Ga. 1933); Lyman v. Suburban R.R. Co., 60 N.E. 515 (Ill. 1901).

398. See Delaware, Lackawanna \& W. R.R. Co. v. City of Oswego, 86 N.Y.S. 1027. 1031-32 (1904); cf. Canadian River R.R. Co. v. Wichita Falls \& N.W. Ry. Co., 166 P. $163,167-68$ (1917) (non-use relevant among other factors).

399. See Kuhlman v. Houston Belt \& Terminal Ry. Co., 283 S.W. 571,572 (Tex. Civ. App. 1926).

400. See Seventy-Ninth St. Improvement Corp. v. Ashley, 509 S.W.2d 121, 123 (Mo. 1974).

401. See, e.g., Oklahoma City-Ada-Atoka Ry. Co. v. City of Ada, 182 F.2d 293 (10th Cir. 1950); Denver \& Rio Grande Ry. Co. v. Mills, 222 F. 481 (8th Cir. 1915). But see Chesapeake Beach Ry. Co. v. Washington, Potomac \& Chesapeake R.R. Co., 199 U.S. 247 (1905); Dunford v. Dardanelle \& R.R. Co., 287 S.W. 170 (Ark. 1926).

402. See Sheldon v. Michigan Cent. R.R. Co., 126 N.W. 1056 (Mich. 1910).

403. See, e.g., Faus v. Pacific Elec. Ry. Co., 303 P.2d 814 (Cal. Dist. Ct. App. 
the contrary..$^{404}$ Removal of trash along the corridor or controlling weeds are also signs that no abandonment was intended despite the removal of tracks and ties. ${ }^{405}$ Obtaining governmental authorization to discontinue or abandon is generally held to be insufficient evidence of an intent to abandon the property rights unless tracks and ties have also been removed. ${ }^{406}$

The showing that must be made to prove abandonment of the rail corridor thus varies radically across the states. Certain states, pursuant to turn-of-the-century anti-railroad animus, have terminated railroad corridor easements upon evidence that would not justify termination of a private easement. ${ }^{407}$ Other states establish a higher standard to demonstrate intent to abandon and consummation of that intent because of the public interest in the corridors. ${ }^{408}$

For the utility company whose property rights depend on the strength of the railroad's rights, the question of abandonment is crucial. ${ }^{409}$ Assuming arguendo that a railroad easement is sufficiently broad to encompass a general utility license or subeasement while the railroad is operating, what effect does abandonment have on the utility's rights if the railroad subsequently abandons its easements or is found to have abandoned its easements prior to granting the utility license? A few general principles give us some initial guidance, but the law at this time remains unclear.

First and foremost is the general principle that termination

1956); City Motel, Inc. v. Dep't of Highways, 336 P.2d 375 (Nev. 1959).

404. See, e.g., Ocean Shore R.R. Co. v. Spring Valley Water Co., 262 P. 53 (Cal. Dist. Ct. App. 1927); O'Brien v. Best, 194 P.2d 608 (Idaho 1948); Sandy River Coal Co. v. Champion Bridge Co., 48 S.W.2d 1062, 1064 (Ky. 1932).

405. See Cleveland \& Pittsburgh Ry. Co. v. Ward, 40 Ohio C.C. 642 (1912).

406. See, e.g., Penn Cent. Corp. v. U.S.R.R. Vest Corp., 955 F.2d 1158 (7th Cir. 1992) (holding that state statute finding abandonment merely on obtaining of ICC discontinuance certificate violated due process clause); Faus v. Pacific Elec. Ry. Co.. 303 P.2d 814 (Cal. Dist. App. Ct. 1956); Lacy v. East Broad Top R.R. \& Coal Co., 77 A.2d 706 (Pa. Super. Ct. 1951).

407. See Cannco Contractors, Inc. v. Livingston, 669 S.W.2d 457, 459-60 (Ark. 1984); see also BRUCE \& ELY, supra note 105, § 9, at 29 ("There is authority for the proposition that courts more readily infer that a public easement has been abandoned than that a private easement has been so relinquished.").

408. One commentator argued that public easements should be more carefully guarded by the courts than private easements because there is no private landowner available who will protect her property rights in the case of the former. 2 ELLIOTT \& ELLIOTT, supra note $106, \$ 1175$. Perhaps the most useful summary of the cases in this area are found in Connelly, supra note 111.

409. This is another reason why these class actions are inappropriate. The states differ dramatically in their definitions of abandonment, so the classes will have to be subdivided by state to determine which corridors have in fact been abandoned. 
of an easement will terminate a sub-easement, just as termination of a head lease will destroy a sub-lease. If the railroad's easement terminates, any rights dependent upon the railroad's rights will fail ${ }^{410}$ unless some legal principle protects the sub-easement from termination. Such legal principles include prescription, prior use, estoppel, shifting public use doctrine, or, as in at least three states, a statute that preserves the utility's rights. ${ }^{411}$ Of course, this is unnecessary for those parcels of the corridor owned by the railroad in fee simple absolute; the utility's rights are already protected.

The incidental use doctrine implies that, if railroads are allowed to lease unused portions of their easements for financial gain, then so long as they continue to collect revenues from a utility license, they are still acting as the owner of the easement. Thus, the act of leasing or granting utility sub-easements evidences intent not to abandon the corridor in question, even if all rail service has stopped. Similarly, if railroads do not lose unused portions of their easements because they are lying fallow, they should not lose them when they allow third parties to use them.

Other methods of saving utility rights post-abandonment by the railroad may be prescription, laches, or estoppel. If a servient landowner has knowledge of the dual servitudes and takes no action to remove the trespass of the utility company upon termination of the railroad easement, she may find herself subject to the utility's claim of easement by prescription. If she undertakes an ejectment action, the utility may have a defense of laches or estoppel if she acquiesced to the utility's use for a sufficient period of time. ${ }^{412}$ Prescriptive rights depend, of course, on whether utilities can acquire property rights by prescription or are barred from doing so under state law. But laches and estoppel may be sufficient to prevent a landowner who slept on her rights from trying to eject a utility company whose lines were

410. See, e.g., Forwood v. Delmarva Power \& Light Co., 1998 WL 136572 (Del. Ch. Mar. 16, 1998); State Highway Comm'n v. Union Elec. Co., 148 S.W.2d 503 (Mo. 1941); Hoffman v. Capitol Cablevision Sys., Inc., 383 N.Y.S.2d 674, 676 (1976); Hinds v. Phillips Petroleum Co., 591 P.2d 697, 699 (Okla. 1979) (holding free alienability of exclusive leasehold interests to sub-lessees); RESTATEMENT OF PROPERTY $\S 450$ (1944); BRUCE \& ELY, supra note 105, § 8.04; Hegi, supra note 44, at 128-29.

411. See infra notes 412-416.

412. See, e.g., Taylor Inv. Co. v. Kansas City Power \& Light Co., 322 P.2d 817. 826-28 (Kan. 1958); Potomac Edison v. Routzahn, 65 A.2d 580 (Md. 1949). But see Pierce v. Cherry Valley Farms, Inc., 63 N.E.2d 46 (Ohio Ct. App. 1945) (holding no adverse possession against the railroad or servient landowner by utility company that remained thirteen years after railroad abandoned). 
known to the landowner. ${ }^{413}$

Also, Indiana, South Dakota, and Iowa have enacted statutes to preserve the utility's rights to remain on the servient land after the railroad has abandoned its corridor, although the statutes do not extinguish the landowner's rights to seek monetary compensation for continued use of the corridor after termination of the railroad's rights. ${ }^{414}$ The Iowa law gives the utilities sixty days to pay the landowner the fair market value of an easement for such facilities. ${ }^{415}$ South Dakota allows the utilities to remain for three years on an abandoned corridor. ${ }^{416}$ These statutes are an important way for states to clarify their common law rulings in this troublesome area. ${ }^{417}$

When railroad corridors were created by federal grants, either as pre-1871 limited fees or post-1875 easements, abandonment is regulated by federal statute. In 1922 Congress enacted the Railroad Right of Way Abandonment Act, ${ }^{418}$ providing that, upon railroad abandonment or forfeiture, as declared by a court of competent jurisdiction, the corridor lands vest back in the United States, or its successors in interest, except for lands running through a municipality, which acquires the federal interest. ${ }^{419}$

The Department of the Interior and the federal courts have

413. Cf. Cincinnati, New Orleans \& Tex. Pac. Ry. Co. v. Barker, 247 S.W.2d 943, 945 (Ky. 1952) (holding that owner could not contest mill's right to structure after acquiescing for many years).

414. See IOWA CODE \$ 327G.77(3) (1997); IND. CODE. \& 32-5-12-11 (1999); S.D. CODIFIED LAWS \$ 49-16A-112 (Michle 1999).

415. See IOWA CODE § 327G.77(3) (1997).

416. See S.D. CodIFIED Laws \$ 49-16A-112-114 (Michie 1999).

417. As an aside, however, both the Indiana and the Iowa law require the utility to negotiate with adjacent landowners who are granted by statute the fee title to the center of the abandoned corridor if their deeds do not describe the actual corridor land. See IOWA CODE \& 327G.77 (1997); IND. CODE \& 32-5-12-10(c) (1999). This ignores the fact that the grantor's heirs or successors in interest to the grantor's retained fee title may in fact be the land owner of the corridor land. The North Carolina Supreme Court found that a similar law granting abandoned rail corridor land to adjacent landowners was a taking under both the state and the federal takings clauses. See McDonalds Corp. v. Dwyer, 432 S.E.2d 165 (N.C. Ct. App. 1993). The Indiana and Iowa laws that allow adjacent landowners compensation, even when their deeds do not describe the corridor land, may raise similar constitutional issues. Ironically, the Iowa law requires compensation by utility companies to the servient landowner, but does not require any compensation to the servient landowner for drainage easements held by drainage districts. See IOWA CODE $§ 468.118$ (1997). Why drainage districts are deemed to hold permanent easements that survive the destruction of the railroad's interests and utility companies is not entirely clear.

418. Act of Mar. 8, 1922, ch. 94, 42 Stat. 414 .

419. See 43 U.S.C. $\$ 912$ (1994). The federal government retains all oil, gas, and other mineral interests in the railroad lands, even if the government has sold to successors in interest. 
determined that under both pre- and post-1871 federal railroad grants, the railroad acquired the subsurface rights to their corridor lands, although not the mineral rights, and could subsequently authorize third-party use along the corridor without requiring federal authorization. ${ }^{420}$ But what happens upon abandonment? According to federal law on railroad abandonment, the railroad's property rights revert to the United States, which then regains control over the subsurface of the corridor for purposes of laying utility lines. ${ }^{421}$ Utilities must negotiate with the Department of the Interior for the rights to lay fiber-optic cable along an abandoned railroad corridor. And if the railroad granted the utility a sub-easement prior to abandoning its subsurface rights and then later abandons; the Department of the Interior has the power to decide whether to validate the pre-existing leases between the now-defunct railroad and the still-viable utility. ${ }^{422}$

In sum, third party users must be cautious in locating their facilities in a railroad corridor as the parcels of the corridor held as easements may terminate upon abandonment and the leases or licenses may thereby fail. Besides the statutory and common law methods of preserving utility rights post-abandonment mentioned above, public policy motives may preserve the use. Even though the railroad may remove its tracks and ties and discontinue services, the corridor still retains its public character, and some states have taken efforts to preserve other public uses even after the railroad leaves. ${ }^{423}$

\section{B. Shifting Public Use of the Railroad Right-of-Way}

Another way to deal with the question of utility rights in railroad corridors is the shifting public use doctrine (SPUD). Under this doctrine, public easements that are transformed to meet changing technologies, but which arguably retain some character of the original easement, will not be found to be

420. See generally PROPOSED INSTALLATION, supra note 121; United States v. Union Pac. R.R. Co., 353 U.S. 112.119 (1957) (holding that the United States retains rights to underlying minerals in right-of-way grant to railroad).

421. See 43 U.S.C. \$ 912 (1994).

422. See generally PROPOSEd InSTALIATION, supra note 121.

423. West Virginia, for example, enacted a rails-to-trails program that provides that "any and all abandoned railroad rights-of-way acquired by the state prior to the effective date of this article are hereby declared held for railroad transportation purposes as of the date of acquisition. . . . Such abandoned railroad rights-of-way shall not revert by operation of law to any other ownership while being held for future railroad use." W. VA. CODE § 5B-1A-6 (1999). 
extinguished or abandoned. Thus a railroad easement may be converted to a highway, and a canal easement may be converted to a logging road without causing abandonment. But the states differ on how they will allow changed uses to be classified within the prescribed use limitations. ${ }^{424}$ Where a railroad corridor must be converted to another use, for example, a road for automobiles, a number of courts have held that this shift in use is permissible because a road for automobiles- just like a railroad- is for the purpose of public transportation. ${ }^{425}$ Those courts hold that the shift in use does not constitute abandonment of the railroad easement because the purpose behind the easement-public transportation- is fulfilled by the new use. Servient landowners to a public transportation easement nevertheless often claim that a shift in use of that easement results in abandonment. ${ }^{426}$ The shifting public use doctrine, however, would deny these plaintiffs recovery:

In its broad outline, the shifting public use doctrinejudicially created as part of the common law- provides that the progression from the public use for which an easement is originally granted to another public use will not constitute an abandonment of the easement ... so long as the new use is deemed permissible by the courts. Whether a new use is deemed permissible entails analysis of the scope and purpose of the original use, the relationship of the new use to the original use, and the public interest considerations in the relationship between the old and new uses. ${ }^{427}$

Although the actual phrase "shifting public use doctrine" was not generally used, the common law has dealt with the issue of changes or increases in utilization of an easement, both within and without the railroad rights-of-way context, for over a century. ${ }^{428}$ In Preseault $v$. United States, the court was asked to decide whether the conversion of a railroad right-of-way to a

424. Compare Washington Wildlife Preservation, Inc. v. Minnesota, 329 N.W.2d 543 (Minn. 1983) (finding that a shift from a railroad to a recreational trail was within the scope of the easement), with Lawson v. State, 730 P.2d 1308 (Wash. 1986) (finding that a shift from a railroad to a recreational trail was not within the scope of the easement).

425. See, e.g., Faus v. City of Los Angeles, 431 P.2d 849 (Cal. 1967); Kansas Elec. Power Co. v. Walker, 51 P.2d 1002 (Kan. 1935); Fogle v. Richley, 378 N.E.2d 472 (Ohio 1978).

426. See, e.g. Connelly. supra note $111, \S 9$.

427. Preseault v. United States, 100 F.3d 1525, 1559 (1996) (Clevenger, J., dissenting) (emphasis added).

428. The Federal Court of Claims on a summary judgment decision was actually the first court to use the phrase "shifting public use." Preseault v. United States, 24 Cl. Ct. 818, 832 (1992). 
hiking trail constituted a taking. That court attributed the genesis of SPUD to railroad scholar Edward L. Pierce, who stated:

The use of property taken by the right of eminent domain is not confined to the precise mode or kind of use which was in view at the time of the taking, but may extend to other modes which were then unpracticed and unknown. When property has been taken for a public use, and full compensation made for the fee or a perpetual easement, its subsequent appropriation to another public use - certainly if one of a like kind-does not require further compensation to the owner. Nor is such compensation required when there is a change in the person or body enjoying or controlling the property taken, or in the conditions upon which the public may use it.

The purpose of opening a highway or street is, to provide the public with a right of passage for persons on foot or riding in carriages or other kinds of vehicles. The use for which this public right is obtained is not confined to the same species of vehicles, drawn by the same kind of power that prevailed at the time of the dedication or appropriation, but admits of the passage and repassage of such other vehicles, operated in such a mode and by such force as an advanced civilization may require . . . .429

...

The property [taken for the purposes of a railroad] is ... to be deemed taken for a public use itself . . . . It does not therefore revert to the owner upon a mere transfer of the railroad to another company, nor upon its appropriation to another similar public use. ${ }^{430}$

The Preseault court also cited as authority a later workpublished in 1888- by Chief Justice Isaac F. Redfield of the Vermont Supreme Court, who wrote:

The mere possibility of reverter to the original owner, or his heirs or grantees, is not regarded... as any appreciable interest requiring to be compensated. . . The most the owner of the fee could claim in such case is to recover compensation for any additional land taken, and for any additional burden imposed upon the land appropriated [above and beyond that imposed by the original highway use], as well as for any

429. Id. at 833 (quoting EdWARd L. Pierce, A Treatise on the LaW of Railroads 233, 234 (Boston: Little, Brown, 1881)).

430. Preseault v. United States, 100 F.3d 1525, 1568 (1996) (Clevenger, J., dissenting) (quoting PIERCE, supra note 429, at 235). 
additional damage to the adjoining lands of the same owner. ${ }^{431}$

In other words, new transportation methods should be permitted without having to compensate the servient estate owners for every new change.

In Faus $v$. City of Los Angeles, ${ }^{432}$ the Supreme Court of California held that a shift in easement use from a railroad rightof-way to a street is permitted without triggering abandonment. The Faus Court found precedent in cases that allowed for change in easement use from a street to a railroad, ${ }^{433}$ a park to a parking lot, ${ }^{434}$ public park to a rubbish dump, ${ }^{435}$ and canals to streets. ${ }^{436}$ In Bernards $v$. Link, $^{437}$ the Oregon Supreme Court held that a shift in use from a railroad right-of-way to a logging road did not cause abandonment, citing a number of cases that supported that result, including the shift in use from carriages to automobiles, ${ }^{438}$ wagon to automobile, ${ }^{439}$ and street railroad to motor bus. ${ }^{440}$

The test for determining whether a shift in easement use is permissible under SPUD is simple: determine whether the purpose of the public easement is for transportation, and then determine if the new use of the easement is also a method of transportation. If so, then the new use is allowed. If the new use is not a method of public transportation, then the easement is deemed abandoned.

In the first step, the court must examine the purpose of the original easement grant. As one court explained: "[t]here are compelling policy reasons consistent with our past cases for treating railroad easements more, rather than less, liberally than other easements. For these reasons, I would look beyond the language to the purpose of the deed." ${ }^{441}$ Under this reasoning, railroad grants should be read to have a purpose of promoting transportation, even if there is no specific transportation

431. Id. at 1568 (quoting Redfield, supra note 57).

432. 431 P.2d 849 (Cal. 1967).

433. See Montgomery v. Santa Ana \& Westminster Ry. Co., 37 P. 786 (Cal. 1894).

434. See Abbot Kinney Co. v. City of Los Angeles, 36 Cal. Rptr. 113, 117 (Cal. Ct. App. 1963).

435. See Griffith v. City of Los Angeles, 346 P.2d 49, 54 (Cal. Dist. Ct. App. 1959).

436. See Wattson v. Eldridge, 278 P. 236 (Cal.1929).

437. 248 P.2d 341 (Or. 1952).

438. See Matteodo v. Capaldi, 138 A. 38, 39 (R.I. 1927).

439. See Strycker v. Richardson, 77 Pa. Super. 252 (1921).

440. See Kansas Elec. Power Co. v. Walker, 51 P.2d 1002 (Kan. 1935) (changing electric street car line to motor bus line did not constitute abandonment).

441. Lawson v. State, 703 P.2d 1308. 1319 (Wash. 1986) (Utter. J.. dissenting). 
language in the grant, because of their combined public and transportation use.

Many other grants, however, contain specific language such as "for railroad purposes only," "for the construction of a railroad," "for transportation purposes only," and the like. On one level, the purpose behind these grants and deeds to the railroads is transportation. As another court stated: "a railroad is a public highway, created for public purposes." ${ }^{42}$ This is also true of other grants for roads, trolley lines, canals, horse-drawn carriage roads, and possibly trails. But not all states view the railroad use limitation expansively to imply general public transportation use.

The second step in the analysis is identifying the new use to see if it fits within the scope of the more broadly defined public transportation grant. If so, sound public policy dictates that the easement should continue even if the technology of the use has changed.

However, another test has been used by some states in place of SPUD - the "reasonably foreseeable" test - which states that a new use of an easement is within the original grant only if the original grantors could "reasonably foresee" the new use. The court in Preseault $v$. United States applied the reasonably foreseeable test in a rails-to-trails case:

It is often said that the parties are to be presumed to have contemplated such a scope for the created easement as would reasonably serve the purposes of the grant... . . This presumption often allows an expansion of use of the easement, but does not permit a change in use not reasonably foreseeable at the time of establishment of the easement. ${ }^{443}$

The Preseault majority used the reasonably foreseeable test to hold that a public trail is outside the scope of a railroad easement, and that by converting to a trail the railroad easement was abandoned. The court stated that:

[w] hen the easements here were granted to the Preseaults' predecessors in title at the turn of the century, specifically for transportation of goods and persons via railroad, could it be said that the parties contemplated that a century later the easements would be used for recreational hiking and biking trails, or that it was necessary to so construe them in order to

442. Id. at 1311 (citing Puget Sound Elec. Ry. v. Railroad Comm'n, 117 P. 739 , $743(1911))$.

443. 100 F.3d at 1542 (quoting Richard R. POWELL, 3 POWELL ON REAL PROPERTY $\S$ 34.12[2] (Patrick J. Rohan ed., 1996)). 
give the grantee railroad that for which it bargained? We think not. ${ }^{444}$

Most courts have not adopted the reasonably foreseeable test because it is unworkable and is bad public policy. The reasonably foreseeable test is predicated on the fiction that grantors of transportation easements have the ability to predict the needs and methods of public transportation fifty or even a hundred years in the future. One might ask how the grantor of a railroad easement in a case like Preseault could possibly "foresee" at the time he or she made the easement grant for a railroad in 1899 that automobiles driving sixty-five miles an hour would someday replace many trains and that there would be in place a nation-wide highway system? Of whom is the court thinking when it implies that the invention of the gasoline automobile in 1889 was "reasonably foreseeable?" How exactly does one go about the imaginative process to "reasonably foresee" the invention of the airplane in 1903? Who could even have "foreseen" in the beginning of the nineteenth century that an easement for horse-drawn carriages might be replaced by a steam locomotive, first built and operated in 1825? On this point, the court in Carter v. Northwestern Telephone Exchange Co. stated:

If there is any one fact established in the history of society and of the law itself, it is that the mode of exercising Ithe publicl easement is expansive, developing and growing as civilization advances.... Hence it has become settled law that the easement is not limited to the particular methods of use in vogue when the easement was acquired, but includes all new and improved methods . . . . And it is not material that these new and improved methods of use were not contemplated by the owner of the land when the easement was acquired, and are more onerous to him than those then in use..$^{445}$

This Article advocates the use of SPUD in cases concerning the change in use of a public transportation easement. SPUD is a far better test to use than the "reasonably foreseeable" test because SPUD effectuates the public policy of allowing the public transportation easement to evolve with time. SPUD is also simpler to use; it does not require the court to second-guess what was "reasonably foreseeable" to a grantor fifty or one

444. Id. at 1542 .

445. Washington Wildlife Preservation, Inc. v. Minnesota, 329 N.W.2d 543, 546-47 (Minn. 1983) (quoting Carter v. Northwestern Tel. Exch. Co.. 63 N.W. 111,112 (Minn. 1895)) (emphasis added). 
hundred years ago, and it is easy to apply. SPUD gives clarity to the otherwise immensely complicated process of determining property rights in transportation easements, particularly railroad easements.

\section{Rails-to-Trails}

One extremely popular shift in the use of railroad easements is the shift from railroads to recreational trails. While cases involving use of a railroad easement as a trail are still being litigated in the courts, as a general rule most new uses of transportation easements are permitted under SPUD, the incidental use doctrine, the reasonably foreseeable test, and the exclusivity rights of the railroads. Courts have allowed shifts in use from a trail to a railroad, ${ }^{446}$ canal to a railroad, ${ }^{447}$ railroad to a road, ${ }^{448}$ railroad to a logging road, ${ }^{449}$ and track to trackless trolley ${ }^{450}$ without finding that the new use effected an abandonment. But conversion from rails to trails arguably stretches the concept more than usual. Instead of converting to new and advanced vehicular technology, the conversion takes us back to a simpler, more primitive form of transportation, a form that some people argue is not transportation at all but rather recreation. ${ }^{451}$

A whole host of recent cases challenge the shift from railroad use to a recreational trail. ${ }^{452}$ The question in these cases is whether trail use is sufficiently like railroad use, or is a reasonably foreseeable transportation use, or does not deviate so significantly from railroad use as to work an abandonment of railroad easements. And the courts are split on whether they will

446. See Brainard v. Missisquoi R.R. Co., 48 Vt. 107 (1874) (plank road to railroad).

447. See Hatch v. Cincinnati, \& Ind. R.R. Co., 18 Ohio St. 92, 121-22 (1868) (allowing railroad company to acquire canal easement with only compensating owner for additional burdens beyond canal).

448. See, e.g., Faus v. City of Los Angeles, 431 P.2d 849, 850, 858 (Cal. 1967): Faus v. County of Los Angeles, 64 Cal. Rptr. 181. 185 (Cal. Ct. App. 1967): Kansas Elec. Power Co. v. Walker, 51 P.2d 1002 (Kan. 1935); Fogle v. Richley, 378 N.E.2d 472 (Ohio 1978).

449. See Bernards v. Link, 248 P.2d 341, 351-52 (Or. 1952).

450. See Anderson v. Knoxville Power \& Light Co., 64 S.W.2d 204, 205 (Tenn. Ct. App. 1933).

451. The Intermodal Surface Transportation Efficiency Act (ISTEA), the federal act providing most funding for conversions of rails to trails, explicitly defines cycling and walking as "transportation." 23 U.S.C. \$ 134 (1994); see also 49 U.S.C. § 5319 (1994).

452. See, e.g., Washington Wildlife Preservation v. Minnesota, 329 N.W.2d 543 (Minn. 1983): Lawson v. State, 730 P.2d 1308 (Wash. 1986). 
construe railroad easements to be general transportation easements, in which case bicycle and pedestrian use easily fits within the scope of the use, or whether they will construe the easement narrowly to allow only railroad uses.

The issue of conversion of rail corridors to trails seems to have first arisen in the late 1970s, before the current corridor conversion trend began. In one early case, Pollnow $v$. State Department of Natural Resources, ${ }^{453}$ the court declined to apply the Faus SPUD analysis to a trail conversion, believing that doing so would unreasonably stretch the limits of Wisconsin state common law dealing with the scope of railroad easements. ${ }^{454}$ The court determined, however, that Congress or the state legislatures could preserve the rights of the public in rail corridors for multiple public uses, including recreation and conservation. ${ }^{455}$

In Schnabel $v$. County of DuPage, ${ }^{456}$ the Illinois Court of Appeals held that the conversion of a railroad right-of-way to a trail constituted abandonment, even though the court acknowledged that "there is authority that an existing easement may be altered or expanded in certain circumstances where no increased burden is imposed upon the servient estate. ${ }^{457}$ The court distinguished those cases because they did not involve abandonment and because the use in those cases was not deemed sufficiently different from railroad use to trigger abandonment. ${ }^{458}$ Of course, the court fell into the fallacy of believing that abandonment could be viewed independently of the shift in use and not as a consequence of it.

As the rail-trail cases continued into the 1980s, many courts followed Pollnow and Schnabel. For instance, in McKinley $v$. Waterloo Railroad Co. ${ }^{459}$ the Iowa Supreme Court did not engage in a SPUD analysis but instead held that a rail-to-trail conversion constituted abandonment of parcels acquired by condemnation. ${ }^{460}$ This holding was in spite of the Iowa Supreme Court's earlier holding in McDonnell $v$. Sheets ${ }^{461}$ that the words "team and wagon" in a deed clause did not restrict the type of

\footnotetext{
453. 276 N.W.2d 738 (Wis. 1979).

454. See id. at 746 .

455. See id.

456. 428 N.E.2d 671 (IIl. App. Ct. 1981).

457. Id. at 678-79.

458. See id. at 679 .

459. 368 N.W.2d 131 (Iowa 1985).

460. See id. at 134-35:

461. 15 N.W.2d 252 (Iowa 1944).
} 
vehicular traffic to the exclusion of the use of automobiles. ${ }^{462}$ In fact, the McDonnell court stated that:

it is the general rule that where a right-of-way is granted it may be used for any purpose to which the land accommodated thereby may reasonably be devoted unless the grant contains specific limitations and the grantee can avail himself of modern inventions, if by so doing he can more fully exercise and enjoy or carry out the object for which the easement was granted. ${ }^{463}$

More importantly, the McKinley court did find that parcels obtained by grant as defeasible fees were converted into fees simple absolute by operation of the state marketable title act and that, at least for those parcels, abandonment and conversion were inapplicable. ${ }^{464}$

By the mid-1980s, however, the tide was beginning to shift. In Lawson $v$. State, ${ }^{465}$ the Supreme Court of Washington held that a state statute authorizing a change in a railroad right-ofway to a trail was unconstitutional insofar as it did not compensate servient landowners for the additional burden, citing only to Pollnow and Schnabel, and failing to discuss the nature of the railroad easement or the character of the trail use. ${ }^{466}$ But although the conversion was struck down, the case generated two strong dissents. Recognizing the problems with the "reasonably foreseeable test," one dissenter pointed out that "Iplarties to a private easement are presumed to have considered 'a normal development under conditions which may be different from those existing at the time of the grant." 467

The Lawson dissenters cited to an important Minnesota Supreme Court case, Washington Wildlife Preservation $v$. Minnesota, the leading case allowing a rail-trail shift. The Minnesota court had looked to the well-established proposition that an easement is "not limited to the particular methods in vogue when the easement was acquired" in deciding that the

462. Id. at 255.

463. Id. (citations omitted).

464. See McKinley. 368 N.W.2d at 138.

465. 730 P.2d 1308 (Wash. 1986). Lawson was cited in King County v. Squire Inv. Co., 801 P.2d 1022 (Wash. Ct. App. 1990), for the proposition that a rail-trail conversion was impermissible after abandonment. However, the court correctly noted that as between the heirs of the original grantor and the adjacent landowners, the heirs were the owners of the underlying fee, even though the court had to stretch to re-interpret clear defeasible fee language to create merely an easement in the railroad. See King County. 801 P.2d at 1025.

466. See Lawson, 730 P.2d at 1312-13.

467. Id. at 1319 (Utter, J., dissenting) (quoting Logan v. Broderick, 631 P.2d 429 (1981)). 
conversion of a railroad right-of-way to a trail did not constitute abandonment. ${ }^{468}$ Moreover, the court stated that "railroads are not viewed strictly as private corporations since they are publicly regulated common carriers. Essentially, a railroad is a highway dedicated to the public use. . . . As such, the rights and duties of a railroad are in most instances determined by constant consultation with the public interest." 469

This view has begun to take hold. In Rieger $v$. Pennsylvania Central Corp.,${ }^{470}$ an Ohio Appeals Court held that the shift in use from a railroad right-of-way easement to a trail did not constitute abandonment in light of precedent that allowed the use of an easement to shift from a canal to a railroad, ${ }^{471}$ and a railroad to another railroad. ${ }^{472}$ Then in Barney $v$. Burlington Northern Railroad Co., ${ }^{473}$ the South Dakota Supreme Court held that reversionary landowners should not be compensated for the shift from a federally granted railroad right-of-way to a trail because, under the federal abandonment statute, no abandonment occurs if the right-of-way is converted to a public highway within one year of abandonment. ${ }^{474}$ Because South Dakota law defines a public highway to include "[elvery way or place of whatever nature open to the public, as a matter of right, for purposes of vehicular travel, ${ }^{475}$ and bicycles and snowmobiles are vehicles, ${ }^{476}$ the public highway exception was held to save the corridor. ${ }^{477}$

Despite the trend in favor of allowing rail-trail shifts, the Court of Appeals for the Federal Circuit struck down a rail-trail shift in the recent Preseault $v$. United States saga. ${ }^{48}$ In a poorly reasoned opinion, the court held that a Vermont railroad rightof-way could not be converted to a trail because it had been abandoned due to disuse. The court did not apply SPUD, stating that "[a]s an initial matter, we have found no Vermont case, either in this century or the past, and the parties point to none, in which the Vermont courts establish or apply something called

468. Washington Wildlife Preservation v. Minnesota, 329 N.W.2d 543, 547 (Minn. 1983).

469. Id. at 546.

470. 1985 WL 7919 (Ohio Ct. App. 1985) (unpublished opinion).

471. See id. at 4 (citing Hatch v. Cincinnati \& L.R. Co., 18 Ohio St. 92 (1864)).

472. See id. (citing Garlick v. Pittsburgh \& W.R. Co., 67 Ohio St. 223 (1902)).

473. 490 N.W.2d 726 (S.D. 1992).

474. See 43 U.S.C. $\$ 912$ (1994).

475. S.D. CODIFIED LAWS \$ 31-1-1 (Michie 1999).

476. Id. § 32-14-1.

477. See Barney, 490 N.W.2d at 732.

478. 100 F.3d 1525 (1996); see WRGHT, supra note 133, at 758. See generally Sennewald, supra note 147. 
the 'shifting public use' doctrine." ${ }^{279}$ Technically the court is correct, as no Vermont court had "established" or even "applied" something "called" SPUD. But as the dissent vigorously pointed out, Vermont courts, while not using the phrase "shifting public use," have nevertheless routinely allowed for the shift in use of railroad rights-of-way. ${ }^{480}$

One such early Vermont case is West $v$. Bancroft. ${ }^{481}$ In West, the Vermont Supreme Court permitted a reservoir, or cistern, to be built on a public highway easement without compensation to the servient landowner. The court stated that "[t]he power of the public over highways is not confined to their use for sole purpose of travel." ${ }^{482}$ In another Vermont case, Brainard $v$. Missisquoi Railroad. Co., ${ }^{483}$ the Vermont Supreme Court held that servient owners of a plank road easement did not have to be compensated when that plank road was converted into a railroad. For a number of reasons mentioned throughout this Article, the Preseault decision seems of questionable merit. ${ }^{484}$ Indications are that the decision is limited on its facts and that the other circuits are not following it. ${ }^{485}$

The most recent and, hopefully, final word on rail-trail conversions is Chevy Chase Land Co. $v$. United States. ${ }^{486}$ The Maryland Court of Appeals reasoned that, because a railroad is analogous to a public highway, and because Maryland highway cases regularly acknowledge shifting uses to accommodate new transportation technologies, a rail-to-trail conversion did not work an abandonment. The court focused on the public character of the railroad easement, ${ }^{487}$ the compatibility of trail use with prior uses, ${ }^{488}$ and the reasonableness of the burden. ${ }^{489}$ The court noted that "although use as a hiker/biker trail "was

479. Presault, 100 F.3d at 1541.

480. See id. at 1569 (Clevenger, J., dissenting).

481. 32 Vt. 367 (1859).

482. $100 \mathrm{~F}$.3d at 1569 (Clevenger, J., dissenting).

483. 48 Vt. 107 (1874).

484. This decision is particularly suspect as the abandonment issue had been fully decided by the Vermont Supreme Court earlier when they found no abandonment had occurred. Yet the Federal Circuit redecided the issue of abandonment. Additionally, it did not appear that the Preseaults had title to the corridor land in their deeds. See State v. Preseault, 652 A.2d 1001 (Vt. 1994).

485. The Eighth Circuit in Moore $v$. United States limited the takings challenge to an opt-in class and the District Court for the District of Kansas dismissed the class certification in Swisher $v$. United States.

486. 733 A.2d 1055 (Md. 1999).

487. See id. at 1074-76.

488. See id. at 1076-77.

489. See id. at 1077-79. 
not actually contemplated by any of the parties to the acquisition and grant,... it may be said to have been within the legal contemplation of all that it was to be used for all purposes by which the object of its creation, as a public highway, could be promoted."'490 The Maryland court used the language of the "instrumentality" of the easement to find that, just as fiber optics have replaced telegraph lines as the instrumentality of telecommunications easements, bicycles and skates have replaced railroad cars as an instrumentality of the public railroad easement. And unlike the courts in most previous decisions, this court examined at length the relationship between abandonment of state law property rights and abandonment under federal ICC regulations. ${ }^{491}$

When courts apply SPUD to decide whether the use of a transportation easement as a trail is permitted, a great deal hinges on the court's characterization of the trail. The concurring opinion in Preseault stated: "Realistically, nature trails are for recreation, not transportation. Thus when the State [of Vermont] sought to convert the easement into a recreational trail, it exceeded the scope of the original easement and caused a reversion. ${ }^{\text {"492 }}$ Similarly, the Supreme Court of Washington in Lawson, characterized the trail at issue as a "recreational trail or a nature trail," and went on to hold that a rail-to-trail shift in easement use constituted abandonment of the easement. ${ }^{493}$ Use of a railroad corridor as a trail is not for transportation purposes according to these courts. But as the dissent stated in Lawson:

Railroads have been used to haul freight and transport travelers bent on business or social purposes. Those purposes were often realized in the course of transit, as well as after passengers debarked. The meeting in the club car, the vacation spent sightseeing from a Domeliner, as well as local tourist and commuter trains evidence the diversity of legitimate "transportation purposes." Analogously, while many might travel the proposed trails for recreation purposes, others will use the right of way to commute to work, thus easing pressure on our other severely pressed transportation systems. My point in this comparison is to underscore the insignificance of the difference in transportation media. Just as with a railroad line, the

490. Id. at 1076-77 (citations omitted).

491. See id. at 1081-94.

492. 100 F.3d at 1554 (Rader, C.J., concurring).

493. Lawson v. State, 703 P.2d 1308 (Wash. 1986). 
maintenance of a trail is to furnish transportation. ${ }^{494}$

And the Chevy Chase court further explained that "[t]he fact that the right-of-way may be used for recreational as well as transportation purposes has no bearing on our analysis, since the 'recreation' involved-biking and hiking-consists of the enjoyment one may have in transporting oneself." 495

When a court confronts the question of whether a new transportation use is permitted in an existing transportation easement without triggering abandonment, that court should apply the SPUD and consult the abundant cases available in each state. However, because a few courts have already held that the shift from rails to trails is an impermissible shift in use and therefore triggers abandonment of the railroad easement, ${ }^{496}$ there are two alternative approaches. The first is to accept the railroad abandonment and turn to state statutes that will preserve the trail upon payment of damages to the servient estate owner or condemn the parcels held in easement for nominal damages.

The second, if the railroad has not yet initiated STB proceedings, is to railbank the corridor, which effectively preempts state law property rights and holds the railroad easements alive during the period of trail use. Railbanking is not a difficult procedure, but it must be accomplished with the cooperation of the railroad and concurrently with federal abandonment procedures.

\section{Railbanking}

Responding to the rapid and unsettling rate of railroad abandonments throughout the 1970 s and to demands for more parks and recreational spaces in our over-developing cities, Congress passed an amendment in 1983 to the National Trails Systems Act (NTSA) allowing railroads to dismantle their tracks and relieve the financial burden of maintaining the corridor while keeping the corridor intact. ${ }^{497}$ By doing so, the railroad has "railbanked" its corridor. The easements remain alive for possible future reactivation of rail service, which Congress has declared to be a railroad purpose. As the Act states:

Consistent with the purposes of this Act, and in furtherance of the national policy to preserve established railroad rightsof-way for future reactivation of rail service, to protect rail

494. Id. at 1320 (Utter, J., dissenting).

495. 733 A.2d at 1078 .

496. See Lawson, 730 P.2d at 1312.

497. See 16 U.S.C. \& 1247(d) (1994). 
transportation corridors, and to encourage energy efficient transportation use, in the case of interim use of any established railroad rights-of-way . . . , if such interim use is subject to restoration or reconstruction for railroad purposes, such interim use shall not be treated, for purposes of any law or rule of law, as an abandonment of the use of such rightsof-way for railroad purposes. ${ }^{498}$

Therefore, Congress has determined that preservation of the corridor, by itself, is a railroad purpose of the highest national significance. Accordingly, the servient estate remains burdened by the easement, even if it is not then in use.

The railbanking statute has been held by the United States Supreme Court to constitute a legitimate exercise of Congress's interstate commerce powers; the importance of preserving corridors for future use easily met due process challenges that had been leveled against the statute. ${ }^{499}$ It may sound odd that "non-use" of a railroad corridor could in fact constitute a railroad purpose, but that is indeed what Congress intended-that maintaining the corridor intact during a period of nonuse, if done to preserve the corridor for future railroad use, does not constitute abandonment.

Servient landowners have leveled a series of challenges against the railbanking statute, most recently in the Federal Court of Claims, arguing that, by postponing the date the railroad is deemed to have abandoned, they have suffered a taking of their contingent reversionary rights or of the unburdening of their estates that would have otherwise occurred pursuant to state law. ${ }^{500}$ They further argue that, because surface use of the burdened land would have been transferred to them upon the railroad's abandonment of the property, the railbanking statute works a taking of that railroad easement into perpetuity. ${ }^{501}$

Their argument, of course, begs the question of whether preservation of the corridor can constitute a use for "railroad

498. Id.

499. See Preseault v. I.C.C., 494 U.S. 1, 17-19 (1990) (leaving open takings question).

500. See, e.g., Preseault v. United States, 100 F.3d 1525, 1550-51 (Fed. Cir. 1996); Glosemeyer v. Missouri-Kan.-Tex. R.R., 879 F.2d 316, 323 (8th Cir. 1989); National Wildlife Fed'n v. I.C.C., 850 F.2d 694, 696 (D.C. Cir. 1988); Swisher v. United States., 189 F.R.D. 638 (D. Kan. 1999); Seger v. United States, No. 4:99-CV03056 (D. Neb. filed Feb. 15, 1999).

501. See Preseault v. United States, 100 F.3d 1525, 1550-51 (Fed. Cir. 1996); see also Preseault v. United States, 27 Fed. Cl. 69 (1992); Preseault v. United States, 24 Ct. Cl. 818 (1992). 
purposes" and whether nonuse of the corridor under the relevant state law would even work an abandonment. Hence, all the issues of state law doctrines of abandonment arise, complicating the question of whether the Trails Act actually took anything that the landowners were entitled to under their state law. If, for instance, their state common law recognized SPUD, the shift to a trail would not be an additional burden, and no taking would have occurred by operation of the federal railbanking law. ${ }^{502}$ Although this is the first national program designed to preserve rail corridors, the statute does nothing more than codify what is at the heart of most state's laws on abandonment - that nonuse alone, in the absence of intent to abandon, will not extinguish a railroad easement. ${ }^{503}$

The issue ultimately returns to intent. Prior to 1983 , states usually concluded that ICC abandonment authorization, along with nonuse and removal of tracks and ties, was clear evidence of intent to abandon the corridor property rights. ${ }^{504}$ But with the railbanking statute, preservation or nonuse is now identified as a railroad use. Although this should not pose any great conceptual difficulties to states trying to decide if a railbanked corridor has been abandoned since railbanking clearly negates the requisite intent, ${ }^{505}$ the statute does marginally change the rules of abandonment by specifying that preservation is a legitimate railroad use. ${ }^{506}$ If the railroad intends to preserve its property rights for possible future reactivation, then it does not have the requisite intent for abandonment. ${ }^{507}$ Railbanking is a presumptive showing of intent not to abandon.

In addition to railbanking, the NTSA Amendments of 1983 permit the STB to authorize interim trail use on the railroad

502. See Chevy Chase Land Co. v. United States, 733 A.2d 1055, 1077-78 (Md. 1999).

503. The railroad's actions in railbanking its corridor would seem to disprove any allegation of intent to abandon. Why railbank if the railroad could simply sell the land and be done with it? See Birt v. Surface Transp. Bd., 90 F.3d 580 (D.C. Cir. 1996) (finding that negotiation for a trail showed intent not to abandon).

504. See, e.g., City of Manhattan Beach v. Superior Court, 914 P.2d 160, 163, 171 (Cal. 1996); St. Louis County v. St. Appalonia Corp., 471 S.W.2d 238, 240 (Mo. $1971)$.

505. See Birt, $90 \mathrm{~F} .3 \mathrm{~d}$ at 586-87 (showing that negotiations and going through railbanking procedures evidences intent not to abandon).

506. Maine, for example, has passed a statute declaring that abandonment of services does not imply that the property rights have been abandoned, and that any agency showing interest in the eventual restoration of services shall have priority and the line will not be considered abandoned. See ME. REV. STAT. ANN. tit. 23, § 7105(B) (West 1998).

507. See Birt, 90 F.3d at 586-87. 
corridor. To approve trail use, the STB must find that the use is "not inconsistent" with preservation of the corridor for possible future rail reactivation; the trail use must give way if the corridor is reactivated. ${ }^{508} \mathrm{~A}$ trail operator who wishes to convert a railroad corridor to a trail must work with the STB during the abandonment proceedings to acquire approval to operate the trail on the corridor. ${ }^{509}$

Although the preservation of the corridor should unquestionably be deemed a continuing railroad use, some cases have argued that the conversion to a trail constitutes an impermissible burden on the easement by adding a new use. ${ }^{510}$ These arguments would seem to be defeated by the incidental use doctrine; the trail use is just like the utility's use or a warehouse lease, an additional use that is not inconsistent with the railroad use. Trail use is somewhat more complicated, however, because the railroad sells its property interests in the corridor to the trail operator. That operator may go on to license utility use alongside the trail. As one can imagine, litigation looks to be quite active on whether this is permissible, though to date utility licenses in railbanked corridors have not been addressed.

The legality of railbanking was firmly established by the U.S. Supreme Court in Preseault v. ICC in 1990. ${ }^{111}$ The Court left open the question of whether the postponement of the servient landowners' reversionary interests under state law constituted a taking of their property. The Federal Circuit later decided that the plaintiffs had suffered a taking, but the checkered past of the Preseault litigation, however, calls into question its applicability to future litigation in this area. ${ }^{512}$ Nevertheless, with the

508. 16 U.S.C. $\$ 1247$ (d) (1994).

509. See Melons Grown in South Texas; Increased Expenses and Establishment of Assessment Rate, 61 Fed. Reg. 248 (1996), for a description of the distinctions between Certificates of Interim Trail Use (CITUs) and Notices of Interim Trail Use (NITUs) and the requirements the trail operator must meet in order to acquire the railroad's railbanked property interests.

510. The Supreme Court held that the imposition of a trail use was within due process and interstate commerce parameters, but left open whether the trail use worked a taking. See Preseault v. ICC, 494 U.S. 1, 15-19 (1990). That issue has been taken up at the lower levels in a variety of cases. See, e.g., Preseault v. United States. 100 F.3d 1525 (1996); Preseault v. United States, 27 Fed. Cl. 69 (1992); Preseault v. United States, 24 Cl. Ct. 818 (1992); Glosemeyer v. Missouri-Kan.-Tex. R.R., 879 F.2d 316 (8th Cir. 1989); Swisher v. United States, 189 F.R.D. 638 (D. Kan. 1999); Seger v. United States, No. 4:99-CV-03056 (D. Neb. filed Feb. 15, 1999).

511. 494 U.S. 1 (1990).

512. The Supreme Court effectively sent the Preseaults to the Court of Claims for pursuance of a remedy under the Tucker Act. In January 1992, the Court of Claims held that under Vermont law the servient landowners had reversionary interests in the railroad right-of-way and that the railroad was abandoned when tracks and 
Preseault victory under their belts, servient landowners in Missouri and Nebraska have challenged the railbanking statute under which the 200-plus mile Katy Trail and 300-plus mile Cowboy Trail were built. ${ }^{513}$ Those cases are still being litigated and will generate enormous controversy if successful. Both of these cases are being litigated under the auspices of Nels Ackerson's Washington, D.C., group, the team responsible for the vast majority of these class action suits against the railroads and the utility companies. ${ }^{514}$

Ultimately the determination of whether the railbanking statute works a taking is a matter of whether state property law deems that the servient landowner's reversionary rights are compensable property interests. For a variety of reasons, we believe that such rights are not compensable. The property interest at stake in the case of railroad easements is the contingent possibility that one's burdened land will become unburdened. That contingency is much like a contingent remainder. Yet contingent remainders are routinely extinguished under the rule against perpetuities, ${ }^{515}$ marketable title acts,

equipment were removed from the corridor. See Preseault v. United States, $24 \mathrm{Ct}$. Cl. 818,832 (1992). Ten months later the Court handed down a second decision in the case, holding that the servient landowner's reversionary interests were not compensable property interests because they acquired their title to the servient land after federal laws had been passed regulating their future interests and because they had no reasonable investment-backed expectations with regard to being able to develop the encumbered corridor. See Preseault v. United States, 27 Fed. Cl. 69, 89 (1992). These decisions were upheld in 1996 by the Court of Appeals for the Federal Circuit in a 2-1 decision. See Preseault v. United States, 66 F.3d 1167 (Fed. Cir. 1996). A few months after that decision was issued, five members of the Federal Circuit bench were treated to an all-expenses paid, five-day seminar on property rights at a resort in Montana paid for by the Foundation for Research on Economics and the Environment. Those justices were Rader, Michel, Plager, Newman, and Mayer. See Marcus, supra note 9, at Al. This Foundation receives funding from the John M. Olin Foundation, which is also a financial backer of the New England Legal Foundation, which litigated the Preseault cases. Upon returning from the seminars, the Federal Circuit reopened the case, sua sponte, and reversed 5-4, finding that a taking had occurred. See Preseault v. United States 100 F.3d 1525. 1550-51 (Fed. Cir. 1996). Under a blistering dissent the Court found that the railroad's property interests had been abandoned pursuant to state law before federal abandonment had been authorized by the ICC. See id. at 1550. The Department of Justice chose not to litigate the issue to the Supreme Court again, and it went back down for a determination of damages.

513. See Glosemeyer v. United States, 45 Fed. Cl. 771 (2000); Swisher v. United States, 189 F.R.D. 638 (D. Kan. 1999); Seger v. United States, No. 4:99-CV-03056 (D. Neb. filed Feb. 15, 1999).

514. See generally Amon, supra note 7.

515. Although possibilities of reversion in the grantor are not subject to the rule against perpetuities, the reversionary interest was generally not transferable to third parties which would allow grantors to avoid the workings of the rule. Because an inter vivos transfer of a possibility of reverter effectively defeats the purpose of the 
presumptions against forfeiture, and rules against alienation of possibilities of reverter. ${ }^{516}$ These are all well-established property rules that inevitably cause the extinction of contingent future interests. Hence, reversionary interests in railroad corridors remain in the grantor or the grantor's heirs, and generally should not be shifted to successors in interest of the adjacent land. ${ }^{517}$

A variety of basic property law principles support the gradual extinction of reversionary rights after the conditions restricting a piece of property have been satisfied for a sufficient period of time. Although easements function differently, the presumption is the same, namely that the removal of the encumbrance is a contingent future interest to which most servient landowners have no investment-backed expectations, so that postponement of the removal of the encumbrance does not work a taking. In the vast majority of cases, the current servient landowners do not have deeds that describe the actual corridor land claimed to be encumbered. ${ }^{518}$ Hence, most of these class action suits are proceeding contrary to the basic premise in property law that one must prove rights to land based on the strength of one's own title, not the weaknesses in the opponent's title..$^{519}$

Even if the basic principles of property law justified these takings claims, the plaintiffs would still be unlikely to show that the conditions of the easement had been violated. Any trail constructed pursuant to the National Trails Systems Act Amendments of 1983 should be deemed a continuing public transportation use under SPUD. In the alternative, any railbanked easement cannot be deemed abandoned because railbanking is a "railroad purpose." Thus, the trail constructed in the railbanked corridor would not be deemed a shift in use but

rule against perpetuities, such transfer would generally destroy the interest. Recently, however, many states have allowed for inter vivos transfers of possibilities of reverter and rights of re-entry but have gotten around the perpetuities problem by also enacting marketable title acts that destroy all future interests after a specified period of time, generally thirty years. Thus, the marketable title act serves to equalize the rather arbitrary limitations on dead hand control that were effected by the rule against perpetuities.

516. See CunNingham ET AL., supra note 77, at 104-07, 126-34, 148-54.

517. See, e.g., Paul v. Connersville \& Newcastle Junction R.R. Co., 51 Ind. 527 (1875); McDonalds Corp. v. Dwyer, 432 S.E.2d 165, 169 (N.C. Ct. App. 1993).

518. See, e.g., Rockwell v. State, 291 N.E.2d 894. 896-97 (Ind. 1973); King County v. Squire Inv. Co., 801 P.2d 1022, 1027 (Wash. Ct. App. 1991) (describing deed as "metes and bound" deed with reference to railroad right-of-way as boundary).

519. Adjacent landowners who try to claim title to abandoned railroad corridors without showing evidence of their own title have had their claims dismissed. See, e.g., Rockwell v. State, 291 N.E.2d 894, 896-97 (Ind. 1973). 
rather preservation of the rail use with an additional incidental use.

Furthermore, even if the courts determine that the servient landowners have suffered a taking, they are entitled only to the difference in value between a railroad easement alone and a railroad easement with the additional servitude of a trail or a utility line. The government must pay only for the additional interest actually taken. ${ }^{520}$ But a railroad easement is presumptively the greatest burden possible to encumbered land. ${ }^{521}$ As the Ohio Supreme Court noted, "There can be no greater burden upon property than that which results from al] [railroad's] appropriation of a right to exclusive use." 522 Therefore, the additional trail use is a nominal burden at best. Realistically, the trail is far less burdensome than when trains ran over the easement. Not only may the servient owner enter the easement (by using the trail) as she could not while rail service was active, but the owner is also relieved of liability for any injuries that might occur on the easement, thus imposing a smaller burden on the servient estate than if it were extinguished. ${ }^{523}$

$\mathrm{V}$

\section{A UNIFIED THEORY OF MULTIPLE-USE RAILROAD EASEMENTS}

From the foregoing, it is quite clear that the states are split on the multiple uses of railroad easements, either by utilities or trail groups, both pre- and post-abandonment. Yet the purpose of this Article is to draw together the different issues that face the parties with interests in a railroad easement to enable lawyers and judges to better understand how the different issues relate to one another.

520. See Branson West, Inc. v. Branson, 980 S.W.2d 604, 607 (Mo. Ct. App. 1998) (holding that an easement holder who, "while lawfully on the servient land, exceeds his rights under the easement... becomes a trespasser to the extent of the unauthorized use").

521. See Chevy Chase Land Co. v. United States, 733 A.2d 1055, 1078 (Md. 1999) (stating that railroad easement is most burdensome use); see also Montange, supra note 105, at 158 (same).

522. Fogle v. Richley, 378 N.E.2d 472, 475 (Ohio 1978).

523. See Sennewald, supra note 147 , at 1423-24.

[T]he Rails-to-Trails Act includes future railroad use as a railroad purpose and that the establishment of a recreational trail could actually be less burdensome than an active railroad easement, most notably because the characteristics of exclusive occupancy disappears. Thus, there is no "shift" in use because the easement is still being used for a railroad purpose [railbankingl, and there is no taking because the additional use is less burdensome than the original use for rail traffic. 
Because of the public interest invested at the creation of these corridors and the importance of railroad corridors to future transportation needs, railroads should be given fairly broad powers while operating on the easements. Furthermore, courts should apply a relatively stringent test on abandonment, so that the railroads are not deprived of their property rights merely for a brief period of nonuse. Courts should take very seriously the most important element in abandonment determinations: intent. In doing so, they would understand how continued maintenance, tax payment, or railbanking evidences an intent not to abandon the easements. Hence, utility and other public uses could continue on these corridors without reacquisition of new corridors at tremendous costs.

Railbanking and interim trail use deal logically with the problems posed by the alarming number of corridors in peril of being abandoned and fractionated. These corridors were constructed in large part with significant public funding and the public's needs in mind. The fact that they have been privately owned should not derogate their importance to the public and their vital role in bringing communications, electric, and gas services to communities that could not afford to attract the utilities on their own. Because the public helped pay for the railroads and were the prime cause for the railroads' existence, the public should have a right to redefine the uses of railroad easements. This is not to say that whatever actions the railroad takes should be permitted, with no reference to the rights and needs of the servient landowners. But it does suggest that corridors that have operated for over one hundred years as transportation and utility corridors should continue to serve the public's changing needs, without fear of damage awards to landowners who may not even own the land underlying the railroad corridor, or who purchased their land with no expectations of the servitude ever being removed.

While the railbanking statute does postpone contingent reversionary future interests, the rule against perpetuities, marketable title acts, and rules against alienation of possibilities of reverter are all well-established and important laws that similarly postpone such interests. Not even the most conservative of property rights advocates has suggested that the five hundred-year-old rule against perpetuities works a taking. Yet all of these rules, as well as the doctrine of shifting public uses, reflect the law's consistent antipathy to contingent future interests. Because of their contingency, they can be legitimately destroyed without raising takings claims. 
A number of policy reasons justify the courts' protecting the rights of the railroads, the utilities, and the public to put these corridors to changed public uses. First, these corridors are quasi-public assets. Although they are held in private ownership, the common carrier duties imposed on the railroads require them to maintain and use the land in particular ways. Railroad liability is far higher than is the liability of the average private landowner. Hence it is not enough to simply find that railroads are privately owned entities, unlike public streets and highways, for they cannot enter into contracts regarding their land that are contrary to the public interest. ${ }^{524}$ As the Ninth Circuit explained:

[The railroad's] franchise from the state... made it to a certain extent a public agent endowed with part of the sovereign power of the commonwealth; and a railroad constructed in this state by a corporation organized under the laws of the state, ... must necessarily be a highway for public use, in and to which the public have rights limited and regulated by law. There is no statute authorizing such a transfer of property in the right of way and control thereof as the plaintiff now claims was made to it by said contract, and, without express authority conferred by a statute, no transfer of such property, or of the right to control the same, could be made, whereby the rights of the public, or a third party ... could be in any manner abridged. ${ }^{525}$

Even the Tennessee Supreme Court, a court that has traditionally been stingy in its grant of powers to the railroads, found that:

[The railroad] is created by the law to serve the public in transportation of freight and passengers. The main object of this creation is the public service. Of course, the stockholders are permitted to make a profit upon the investment; but this is incidental to the granting of the charter, and is not the reason impelling the Legislature to create the company. It has been given its extraordinary powers for the benefit of civilization. ${ }^{526}$

This important public character has motivated some courts to construe rules liberally in favor of the railroads. ${ }^{527}$ And although the railroads have not always been considerate of the

524. See Western Union Tel. Co. v. Postal Tel. Co., 217 F. 533, 538 (9th Cir. 1914); Pacific Postal Tel. Cable Co. v. Western Union Tel. Co., 50 F. 493, 494-95 (C.C.D. Wash. 1892).

525. Pacific Postal, 50 F. at 495.

526. Southern Ry. Co. v. Vann, 216 S.W. 727, 731 (Tenn. 1919).

527. See Midland Valley R.R. v. Sutter, 28 F.2d 163 (10th Cir. 1928); Midland Valley R.R. v. Jarvis, 29 F.2d 539 (8th Cir. 1928). 
needs and feelings of servient landowners, there is no question that they are under tremendous duties as public carriers and thus cannot always operate with the needs of only their neighbors in mind.

Furthermore, the federal railbanking policy reflects a national commitment to preserving these valuable assets. And although branch lines between two rural communities may not seem of vital national importance, we cannot foresee the public's needs fifty or one hundred years from now. Local branch lines may become crucial inter-state links in a future transportation system. A century ago no one would have imagined that Los Angeles and Phoenix would be two of the five largest cities in the country that would benefit tremendously from a high-speed train linking the two. The railbanking statute is one step in what we predict will be greater and greater efforts to preserve rail corridors for future transportation needs. Our roads and highways cannot expand indefinitely, nor can our atmosphere handle the air pollution from trucks and commuters. One way or another, the railroad corridors are going to be part of the solution.

Railbanking may also benefit those very parties who are filing suit; adjacent landowners ultimately benefit more from having well-maintained rail and utility corridors than from abandoned garbage dumps, dangerous wastelands, or a slightly larger backyard. Where the landowner had little or no expectation of the railroad burden being removed, he or she receives a windfall of questionable value. In many cases, rail corridors are polluted by overspraying of pesticides and weed killers or by leaching of creosote into the ground. Often the land is overly compacted or has been excavated and replaced with rock ballast that would prevent agricultural use of the land. Where the land poses these liabilities, transferring the corridor to public or municipal control can guarantee continued maintenance, use, and vitality of a corridor of land that would otherwise lie fallow or become a nuisance if returned to the hands of adjacent landowners.

Moreover, where recreational trail easements or utility easements exist along abandoned rail corridors, adjacent landowners are immune from liability for personal injuries to users and trespassers on the easement when they would not be immune if they absorbed the land back into their own private holdings. Moreover, trail use is likely to raise the value of the servient land. Numerous studies have shown that recreational trails bring tremendous return on their investment, both in 
terms of revenues to local businesses and increases in property values along the trail. An abandoned railroad bed is a magnet for illegal dumping of garbage, trespassing, and illicit activities. Trail uses have been proven to revitalize the land, reduce crime along the corridor, create an ecological greenway that helps clear pollution from the neighboring land, and provide venues for exercise that lead to a healthier and happier citizenry. ${ }^{528}$

Servient landowners also benefit from the utility uses to which rail corridors are put. They benefit from increased 911 services, emergency communications and linkages, clear and inexpensive long distance services, and lower local telephone rates made possible by competition among providers. Such competition cannot occur without multiple uses of utility corridors.

In addition, the burden imposed by utility uses, like that imposed by trail uses, is nominal. Where the burden is substantial, the landowner should be compensated. The Takings Clause of the Fifth Amendment, as interpreted by the United States Supreme Court, would require compensation when there are interferences with property rights that, in all fairness, are so extensive that they should be borne by the public at large. ${ }^{529}$ But trail use and utility use provide more benefits to adjacent land than burdens.

Finally, using rail corridors to lay fiber-optic cable actually hews more closely to the original purposes of the land grants to the railroads than is first apparent. Where we once had the Pony Express, we evolved to railroad carriage of the mail, then telegraph, then telephone, and now internet linkages between people. If a horse and buggy trail can be converted into a road for automobile traffic, then a fiber-optic cable ought to be permitted in a rail corridor where the mail was originally carried from town to town. Although nineteenth-century landowners could hardly expect that we would be communicating through instantaneous computer linkages all over the world, the fact is that new technology has replaced the railroad for certain of its once vital public services. As one judge explained in a highway case:

If it is sound reasoning to say that since telephone and telegraph messages take the place of the messenger and relieve the street of much of the use to which it would

528. See Rails-to-Trails Conservancy, ISTEA \& Trails: Enhancement Funding for Bicycling and Walking (1996).

529. See generally Pennsylvania Cent. Transp. Co. v. City of New York, 438 U.S. 104 (1978); Pennsylvania Coal Co. v. Mahon, 260 U.S. 393 (1922). 
otherwise be subjected, and, therefore, the telephone and telegraph poles and lines are not an additional servitude, why is it not just as sound to hold that electric power lines are not an additional servitude because the electricity takes the place of the coal, kerosene, and wood that would otherwise have to be hauled to the residences and businesses and industries along the highway? ${ }^{530}$

When modern courts blindly follow such out-dated doctrines as the reasonably foreseeable test for shifting easement uses, they ultimately frustrate rather than further the rights of everyone. Laws do not remain static. They must evolve with new circumstances without doing injustice to the rights of those whose expectations relied on the old doctrines. We do not advocate stripping servient landowners of all rights to control uses of their land, but there are limits to how far property rights should be held static in the face of changing needs and expectations. Property rights have never been absolute, and Justice Holmes' warning in 1922, that when a regulation 'goes too far" it will require compensation, still holds sway. ${ }^{531} \mathrm{By}$ understanding the full complex array of issues and interests, judges may better evaluate whether applications of certain laws will "go too far."

\section{CONCLUSION}

The question of the exact scope of the railroad easement and the power to grant licenses to utilities for placement of fiber-optic cables in the railroad corridor may seem like an arcane, technical, and esoteric legal question. But as the above discussion has demonstrated, the legal issues are terribly important for the future development of telecommunications services. The property rights acquired to assemble these valuable corridors may go back one hundred fifty years, but as with the land itself, they will continue for hundreds of years more. Properly understanding these rights, therefore, should be a principal concern to judges and legislators. But proper understanding necessarily entails looking back to the original granting documents to try to fathom the intent of the parties in light of case law at that time. It means understanding the land acquisition practices of the railroads and the role the railroads played in providing public services and using public powers to

530. Berry v. Southern Pine Elec. Power Ass'n, 76 So. 2d 212, 221 (Miss. 1954) (Gillepsie, J., dissenting); see also Crawford v. Alabama Power Co., 128 So. 454, 45758 (Ala. 1930).

531. Pennsylvania Coal Co. v. Mahon, 260 U.S. 393 (1922). 
build their roads. It means understanding how changed times have led to changed legal rules and, more importantly, how to distinguish among the rules that should be kept and those that should be further changed to accommodate the growth of the next century.

It also means recognizing that property rights fluctuate with the changing needs of the people. No one should have to suffer unfairly the loss of property for the benefit of the greater good without just compensation. But the legal rules the courts and legislatures adopt define those property rights and necessarily permit their modification to meet everyone's needs.

It is our position that the one relevant party that has been left out of most of these property disputes is the public, for these rights-of-way are ultimately public highways and public utility corridors. By adopting a comprehensive approach to these cases, we believe the courts can fairly balance the demands and rights of everyone. But doing so cannot occur in ignorance. The goal of this Article has been to provide the background to these disputes among servient landowners, railroads, utility companies, local municipalities, trail groups, and the general public to help create logical, fair-minded rules that will enable interested parties to move into the next century with some certainty of their rights and obligations. 
